\title{
TESTS OF HOLLOW TILE AND CONCRETE SLABS REINFORCED IN ONE DIRECTION
}

\author{
By Douglas E. Parsons and Ambrose H. Stang
}

\section{ABSTRACT}

Beams which represented sections of typical combination hollow tile and concrete floor slabs reinforced in one direction were made and tested in the laboratory for the purpose of obtaining information on the ralue of hollow tiles in resisting bending and shearing stresses. The test pieces consisted of 42 beams from 8 feet 10 inches to 15 feet 3 inches long, all 8 inches in depth and having a maximum width of 30 inches. For the purpose of comparison two concrete beams having the same sectional area as the gross sectional area of the composite beams and three concrete beams having the same sectional area as the concrete ribs in the composite beams were also tested.

Observations were made of the deformation in the concrete, tiles and reinforcement, deflection of the center of the beam, and development of cracks as the loads were applied.

Tables and curres give a summary of the test data, and comparisons are made between these and the usual design computations for reinforced concrete beams.

The results indicate that the tiles assisted the concrete in resisting both bending and shearing stresses. The assistance of the tiles in resisting bending stresses seemed to be approximately proportional to the modulus of elasticity of the tiles. The assistance of the tiles in resisting shearing stresses varied somewhat with the kind of tile, but, in general, added about 50 per cent to the shearing strength of each concrete rib.

\section{CONTENTS}

I. Introduction

1. Purpose -

2. Acknowledgments _._. 467

II. Description of test beams

1. Design _.

2. Construction

3. Storage _. 471

III. Auxiliary tests of the materials___. 471

1. Reinforcement

2. Concrete - 472

3. Hollow tiles

IV. Method of testing beams 47 
V. Results of tests and discussion

1. General behavior of beams during tests_-_-_-_-_-_----

2. Flexural tests on long beams

(a) Experimental data, methods of computation and notation

(b) Concrete beams

(c) Combination beams with no topping

1. Concrete deformations, depth to the neutral axis, deflections, and steel stresses

2. Maximum bending moments and computed stresses

3. Effect of mortar joints

(d) Combination beams with topping

(e) Distribution of compressive deformations across the beams-_-_-_-_-_-_-_-_-_-_-_-_-_-_--- 506

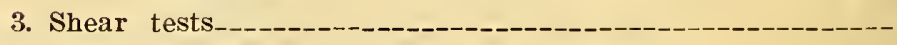

(a) Beams without web reinforcement__________. 506

(b) Beams with web reinforcement_-_____-_-_-_-_ 511

VI. General comments_-__- 512

VII. Summary

\section{INTRODUCTION}

\section{PURPOSE}

In the design of floor slabs of a combination of hollow tiles and concrete, reinforced in one direction, there has been an uncertainty legarding the extent to which the tiles could be relied upon to resist bending and shearing stresses. Slabs of hollow tiles and concrete reinforced in two directions have been the subject of investigations ${ }^{1}$ which have helped to establish a basis for their design. The action of the tiles in these two types of slabs does not seem to be strictly analogous, for in the two-way type each tile is completely surrounded by the concrete, which seems to insure the transmission of stresses through the tile. In the one-way type, however, since the taking of stress by the tiles depends almost entirely upon the adhesion existing between the tiles and the concrete, an analytical treatment must be based upon so many assumptions and approximations that the results could not be considered reliable unless confirmed by tests. Few tests of this kind had been made. The Bureau of Standards, in

1 Slater, Hagener, and Anthes, Test of a Hollow Tile and Concrete Floor Slab Reinforced in Two Directions, B. S. Tech. Paper No. 220. Larson and Petrenko, Loading Test of a Hollow Tile and Reinforced Concrete Floor of Arlington Building, Washington, D. C., B. S. Tech. Paper No. 236. 
cooperation with the Hollow Building Tile Association, therefore, conducted a series of tests in order to obtain information which might serve as a basis for design. The tests were planned to obtain information on (1) the value of the tiles in resisting bending and shearing stresses, (2) the effect of the physical properties of the tiles, (3) the effect of mortar in the cross joints between the tiles.

\section{ACKNOWLEDGMENTS}

The Hollow Building Tile Association, Chicago, Ill., cooperated by paying for the construction of the test beams. Their representative, F. J. Huse, chief engineer of the association, assisted in planning the investigation. The bureau staff supervised the construction of the beams, made the tests, and prepared this report.

The authors are indebted to several members of the bureau staff, especially to S. H. Ingberg, W. A. Slater, and N. D. Mitchell for their advice and assistance.

\section{DESCRIPTION OF THE TEST BEAMS}

I. DESIGN

The tests were made on beams representing sections of typical fioor slabs. The size of the beams was chosen so that they could be conveniently loaded in a testing machine. The dimensions and details of the beams are shown in Figures 1 and 2. All beams had a total depth of about 8 inches. Those beams containing tiles consisted of two 4-inch concrete ribs separated by a single row of tiles, laid with their cells parallel to the length of the beam, and inclosed on each side by a row of tile sections which had been cut to include but one vertical shell and one vertical web. The cutting of the tiles so as to include less than one-half their total width was necessary on account of the limits imposed by the clearance between the screws of the testing machine. The beams were assumed, however, to be equivalent to two units of width in a completed floor slab where each unit of width is a strip 16 inches wide consisting of one 4-inch reinforced concrete rib and one-half of each of the adjacent rows of tiles.

The joints were staggered to bring the joints of the outer tiles opposite the centers of the middle tiles. The solid concrete beams $A$ and $I$ (figs. 1 and 2) had the same sectional area as the gross sectional area of the composite beams, and the concrete beams $B$ (fig. 1) had the same sectional area as the area of the concrete ribs in the composite beams. 
The long beams were made to represent freely supported slabs and the short beams were made to represent sections of slabs continuous over supporting girders. General views of these are given in Figures 3 and 4.

The beams had more reinforcement than is commonly used in floors. Previous tests ${ }^{2}$ have indicated that test beams constructed with the usual percentage of reinforcement ordinarily fail by yielding of the steel in tension. Since in these tests it was desired to study the comparative value of the concrete and hollow tiles in resisting stresses, a higher percentage of reinforcement was used. Four $7 / 8$-inch round deformed bars were used as tension reinforcement in each beam. Based on the sectional area of the concrete only, this gives 1.27 per cent reinforcement for the 29 -inch solid concrete beams ( $A$, fig. 1 and $I$, fig. 2 ) and the long combination beams with topping ( $H$, fig. 1 ) and 4.58 per cent for all the other beams. The bars in the long beams (bars $A$, fig. 1 ) were anchored with semicircular hooks beyond the supports, and the combination beams were provided with a concrete section at each end to join the two units. On the short beams the distance which the bars (bars $D$, fig. 2) were embedded in the concrete was depended upon to prevent slipping.

\section{CONSTRUCTION}

The beams were made by a local contractor experienced in this type of building construction. He was instructed to make the test pieces with the same care that is ordinarily used for construction of this kind. The labor and all of the materials except the tiles were supplied by the contractor. Since the contract was awarded on a lump-sum basis, there was no incentive for the contractor to produce specimens superior to those desired.

In order that the beams might be approximately the same age when tested, the construction was extended over a period of nine weeks. All of the beams constructed in one week were made on the same day. The first 14 beams made were constructed outdoors, but for convenience in moving, the remaining beams were constructed in a laboratory having an overhead crane. The date on which each beam was made is included in Table 6 .

2 See, for instance, National Fire Profing Co., "Collation of tests of the resisting qualities of Natco hollow tile fireproofing," 1914. Building Research Board of Great Britain Special Report No. 2, "Experiments on floors," London, England, October, 1921. 
The wood forms for the beams were prepared and the reinforcement and tiles placed before any of the concrete was placed, so that the concrete for all the beams to be made on that day could be poured
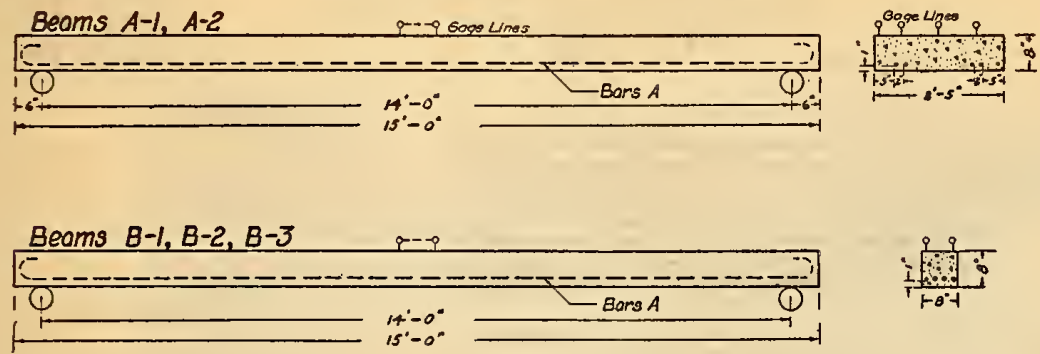

Beoms $C-1, C-2, C-3,0-1,0-2,0-3, E-1, E-2, E-3$

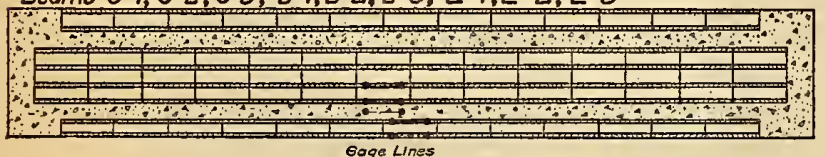

Gage Lines
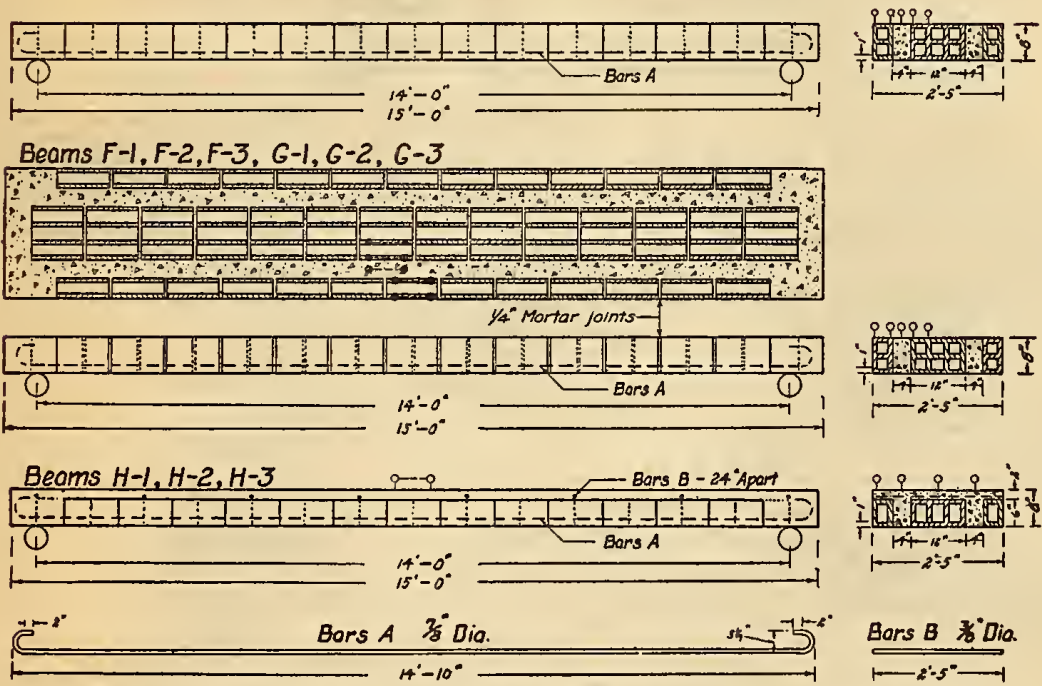

FIG. 1.-Details of long beams and location of gauge lines

Beams $A$ and $B$, solid concrete. Beams $H$ contained 3-cell, 6 by 12 by 12 inch partition tiles of Indiana surface clay (lot 1). Beams $C$ and $F$ contained 6-cell, 8 by 12 by 12 inch load-bearing wall tiles of Indiana surface clay (lot 2). Beams $D$ and $G$ contained 6-cell, 8 by 12 by 12 inch load-bearing wall tiles of Ohio fire clay (lot 3 ). Beams $E$ contaitied 6-cell, 8 by 12 by 12 inch load-bearing wall tiles of Kentucky shale (lot 4).

continuously. In order to prevent the concrete from flowing into the cells of the tiles at the end of each row, these were blocked with fragments of broken tiles. The tiles were wetted a few minutes before the concrete was placed. 

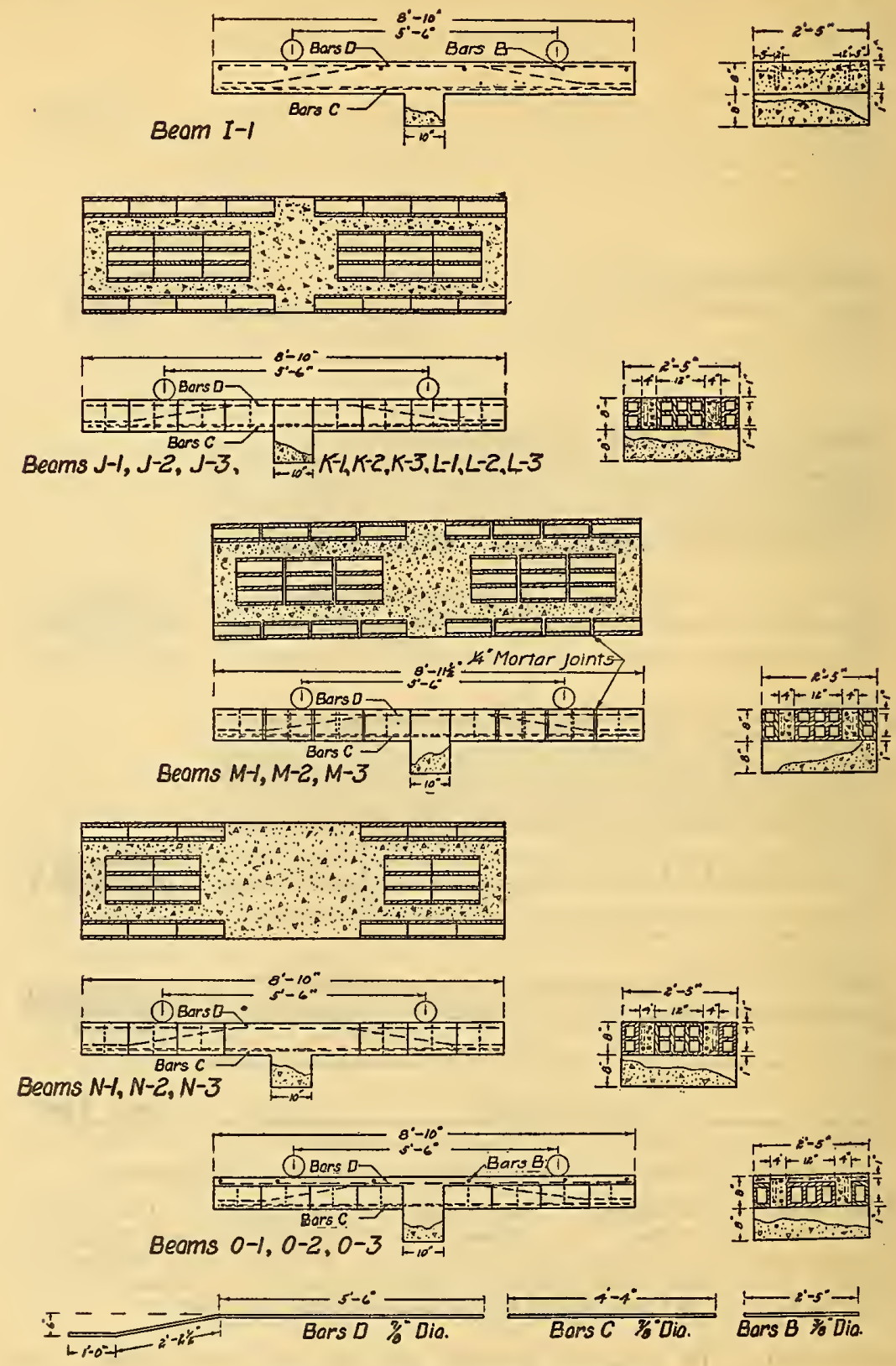

FIG. 2.-Details of short beams

Beam $I$, solid concrete. Beams $O$ contained 3-cell. 6 by 12 by 12 inch partition tiles of Indiana surface clay (lot 1 ). Beams $J$ contained 6-cell, 8 by 12 by 12 inch load-bearing wall tiless of Indiana surface clay (lot 2), Beams $K, M$, and $N$ contained 6 -cell, 8 by 12 by 12 inch load-bearing wall tiles of ohio fire clay (Iot 3 ). Beams $L$ contained 6-cell, 8 by 12 by 12 inch load-bearing wall tiles of Kentucky shale (lot 4). 
Technologic Papers of the Bureau of Standards, Vol. 19

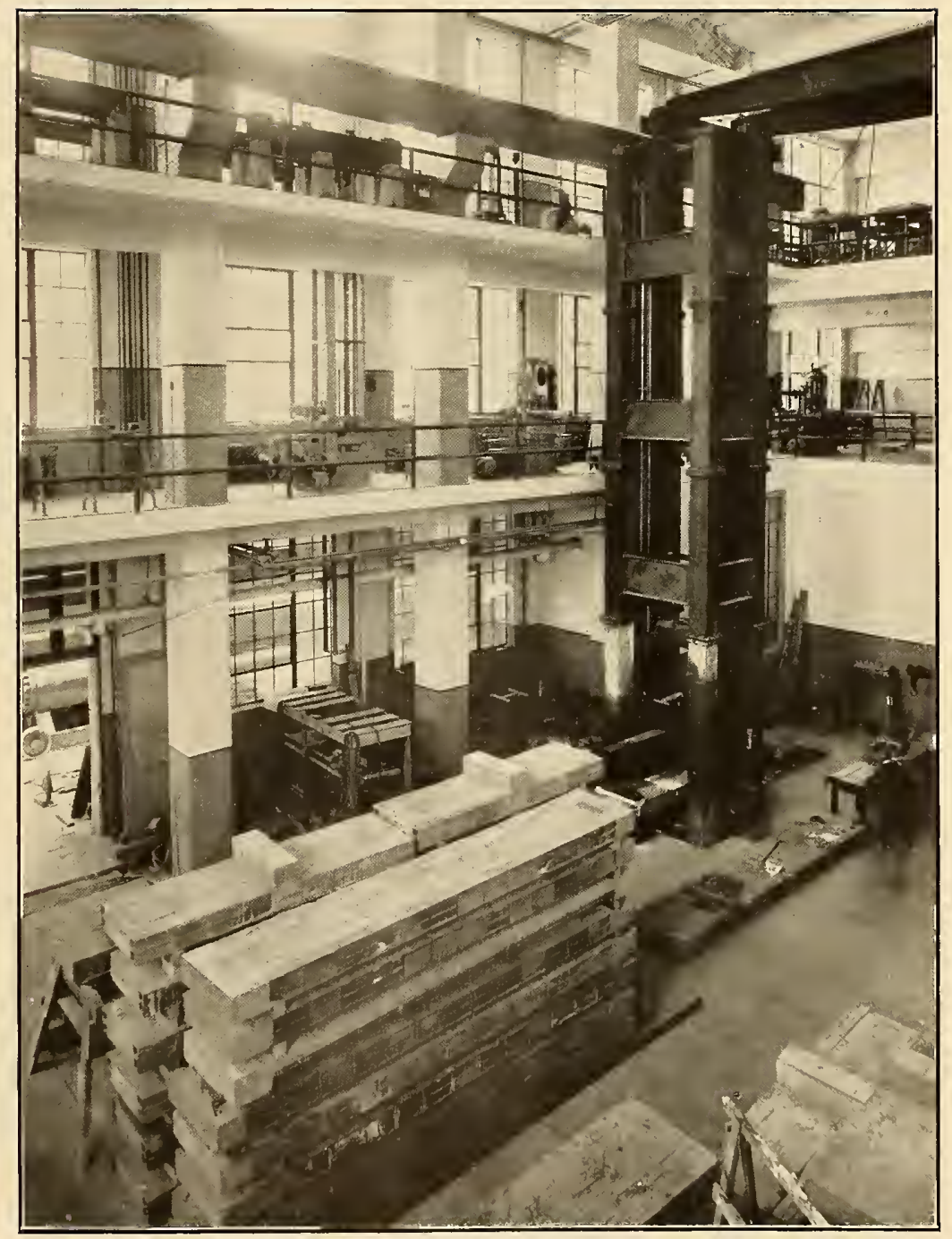

FIG. 3.-Beams stored in the laboratory 
Technologic Papers of the Bureau of Standards, Vol. 19

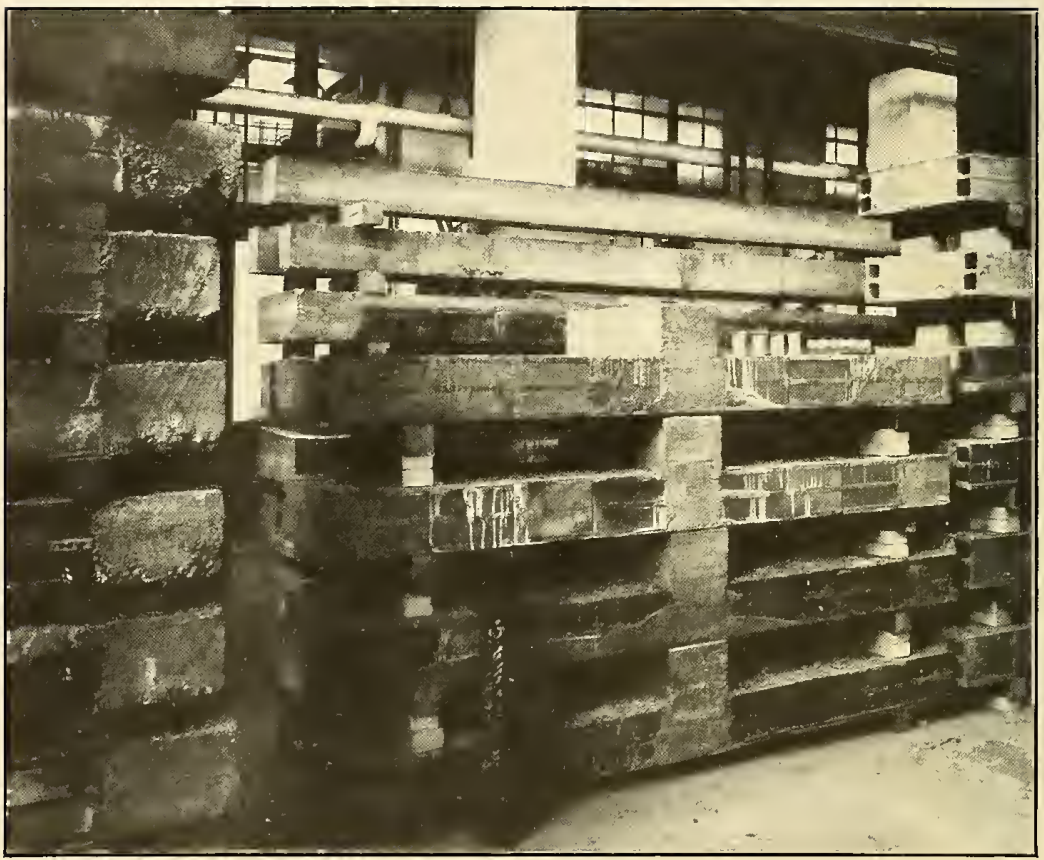

Frg. 4.-Side view of beams stored in the laboratory

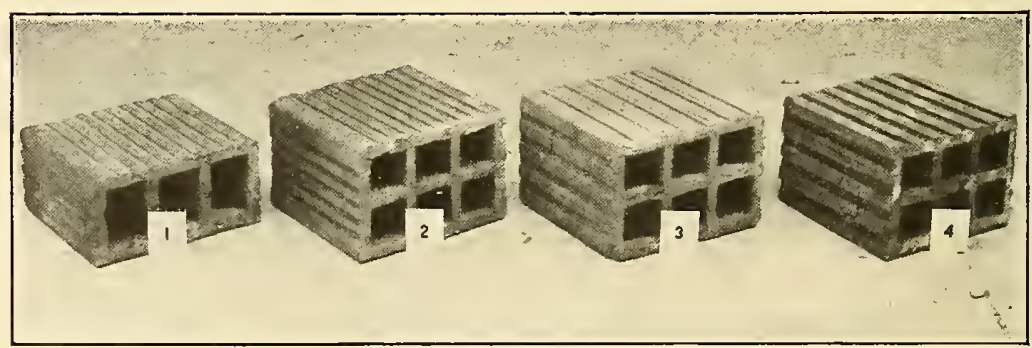

Frg. 5.-Hollow tiles

Lot 1: 3-cell, 6 hy 12 by 12 inch partition tile of Indiana surface clay.

Lot 2: 6 -cell, 8 by 12 by 12 inch load-bearing wall tile of Indiana surface clay.

Lot 3: 6-cell, 8 by 12 by 12 inch load-bearing wall tile of Ohio fire clay.

Lot 4: 6-cell, 8 by 12 by 12 inch load-bearing wall tile of Kentucky shale. 
The aggregate was proportioned by loose volume with the wheelbarrows used to transport the materials to the mixer. One bag of Portland cement weighing 94 pounds was assumed as 1 cubic foot. This method of proportioning was not accurate, but as the laborers were careful in properly filling the wheelbarrows, the volumes of which had been previously determined, the average of several batches probably approximated the desired proportions.

The mixing water was not prescribed but was determined by the workman who placed the concrete in the forms. The workman had difficulty in placing the concrete in the 4-inch ribs containing two $7 / 8$-inch reinforcing bars unless the concrete contained sufficient water to flow quite readily. This difficulty was increased somewhat by the absorption of part of the mixing water by the tiles. Consequently, the concrete as it came from the mixer was not of uniform consistency, but always contained sufficient water to flow readily from the wheelbarrows into the 4 -inch spaces between the rows of tiles. Only a small amount of puddling with a shovel was done.

\section{STORAGE}

When there was danger of injury to the concrete from freezing, the beams which were stored outdoors were covered with canvas and straw; at other times they were exposed. The beams were not removed from the forms until they had aged for at least three weeks. They were then piled in the laboratory as shown in Figures 3 and 4. The duration of the outdoor and indoor storage is included in Table 6. The temperature of the laboratory in which the beams were stored varied between 65 to $75^{\circ} \mathrm{F}$. Because the laboratory was heated the relative humidity was much less than of the air outside, and for this reason the beams and control specimens of concrete, which were fabricated indoors, were sprinkled once each day on the three days immediately following their construction.

\section{AUXILIARY TESTS OF THE MATERIALS}

\section{REINFORCEMENT}

The tension reinforcement in all beams consisted of round deformed billet steel bars, $7 / 8$ inch in diameter. Round deformed bars $3 / 8$ inch in diameter were used for transverse reinforcement in the beams having a concrete topping. The reinforcement was supplied by the contractor, who purchased it in the open market. Five coupon specimens were tested for modulus of elasticity, proportional limit, yield point, tensile strength, and elongation. The results of the tests are given in Table 1 . It is seen that this material $43356^{\circ}-25-2$ 
corresponds to the structural-steel grade for deformed billet steel concrete reinforcement bar's as specified by the American Society for Testing Materials in their specifications A 15-14. ${ }^{3}$

TABLE 1.-Tensile tests of reinforcement

[ $7 / 8$-inch round deformed bars]

\begin{tabular}{|c|c|c|c|c|c|}
\hline Number & $\begin{array}{l}\text { Propor- } \\
\text { tional } \\
\text { limit }\end{array}$ & $\begin{array}{l}\text { Yield } \\
\text { point }\end{array}$ & $\begin{array}{c}\text { Tensile } \\
\text { strength }\end{array}$ & $\begin{array}{l}\text { Modulus of } \\
\text { elasticity }\end{array}$ & $\begin{array}{l}\text { Elongation } \\
\text { in } 8 \text { inches }\end{array}$ \\
\hline $\begin{array}{l}1 \\
2 \\
4 \\
4\end{array}$ & $\begin{array}{r}\text { Lbs./in. }{ }^{2} \\
38,500 \\
39,000 \\
38,600 \\
24,200 \\
39,600\end{array}$ & $\begin{array}{r}\text { Lbs./in. }{ }^{2} \\
39,700 \\
39,300 \\
39,400 \\
37,500 \\
40,000\end{array}$ & $\begin{array}{r}L b s . / i n_{.}{ }^{2} \\
54,500 \\
56,900 \\
59,000 \\
57,200 \\
58,800\end{array}$ & $\begin{array}{l}\text { Lbs./in. } 2 \\
29,400,000 \\
28,900,000 \\
29,000,000 \\
28,000,000 \\
29,000,000\end{array}$ & $\begin{array}{r}\text { Per cent } \\
32.0 \\
30.0 \\
27.5 \\
29.0 \\
30.0\end{array}$ \\
\hline A verage & 35,980 & 39,180 & 57,280 & $28,980,000$ & 29.7 \\
\hline
\end{tabular}

2. CONCRETE

The materials used in making the concrete were all purchased by the contractor on the local market. The concrete consisted of 1 part Portland cement, 2 parts Potomac River sand, and 4 parts $3 / 4$-inch Potomac River gravel and was mixed in a drum mixer. The concrete in the seven beams first constructed was not tested, but for each of the others two control specimens were made. These were both compressive specimens-one a 6 by 12 inch cylinder cast in a standard ${ }^{4}$ steel mold and the other an 8 by 8 by 12 inch'right prism. Two of the 8 by 12 inch sides of the forms for these prisms were composed of the same kind of material, either tile or wood, that was in contact with the concrete in the corresponding beam, and the other two sides and the bottom of the forms were made of oiled wood. All control specimens were stored with the beams within 48 hours from the time they were cast.

The concrete cylinders and prisms were tested at approximately the same age as the corresponding beams. Their compressive strength and modulus of elasticity were determined. Deformations in the concrete were measured over an 8-inch gauge length with a clamp type of compressometer having a single micrometer dial reading to 0.0001 inch. The results of these tests are given in Table 2.

${ }^{3}$ American Society for Testing Materials Standards, 1924, p. 141.

" "Standard method of making and storing specimens of concrete in the field, C 31-21," American Society for Testing Materials Standards, 1924, p. 762. 
TABLE 2.-Compressive tests of concrete

[Age at test from 102 to 106 days. Storage the same as for corresponding beams]

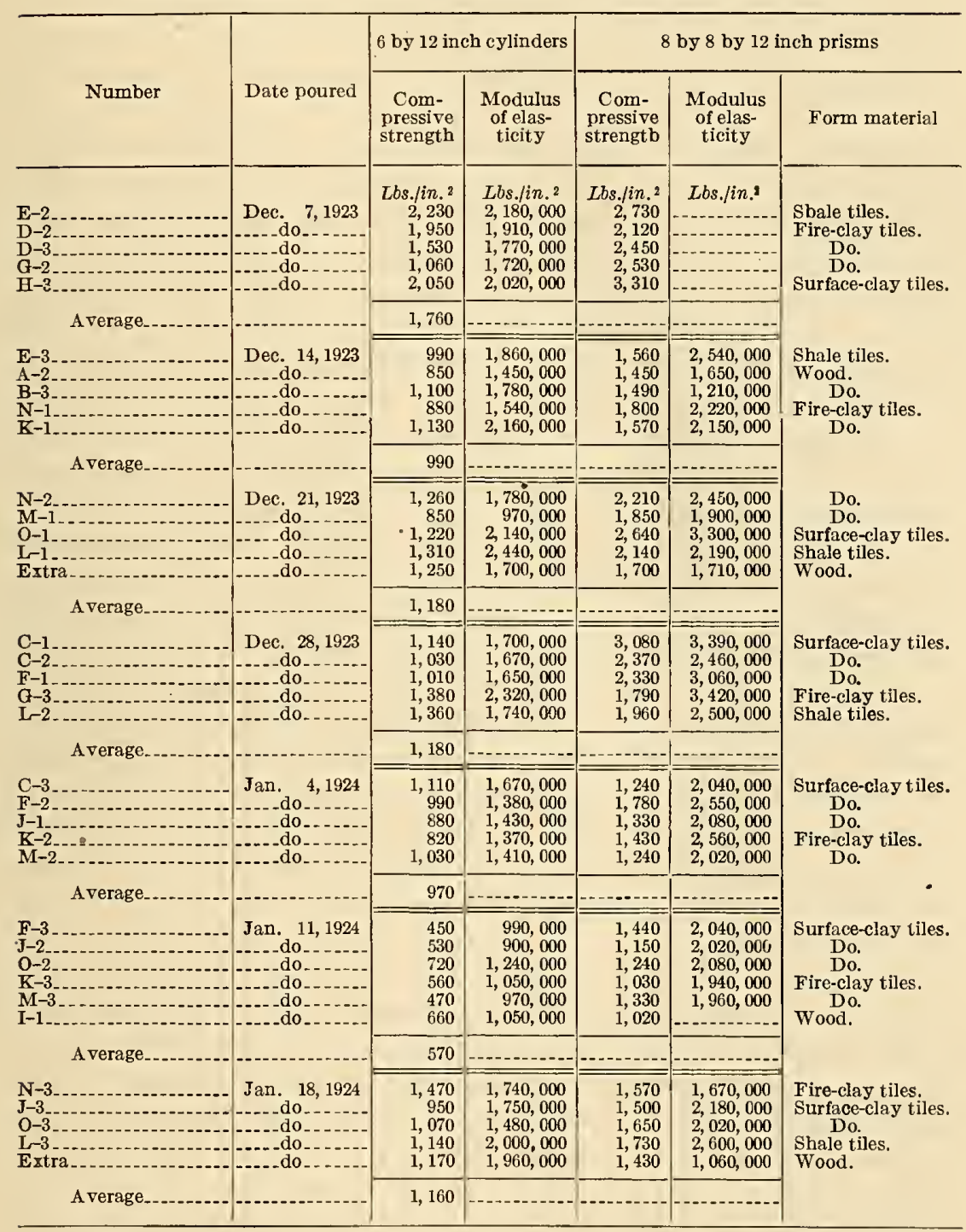


It is believed that the average strength of the concrete in the beams was greater than the strength of that in the cylinders, since some of the most important factors affecting the strength of concrete were different for the cylinders and the beams." The steel molds for the cylinders were substantially water-tight and therefore confined the excess mixing water while the concrete was setting. After the molds were removed the excess moisture evaporated, leaving voids or pores. The forms for the concrete in the beams were porous, and this, together with the cracks between the boards of the wooden forms and between the tiles, permitted much of the excess water to escape before the concrete had set. Experiments have shown that the removal of some of the excess mixing water before the initial set has taken place increases the strength of the concrete by reducing its volume, its water-cement ratio, and its porosity. ${ }^{5}$ Furthermore, many other experiments have shown that the presence of moisture during the curing of concrete is essential for the proper hydration of the cement, and that concrete will gain but little strength after the first three weeks when cured in dry air. ${ }^{6}$ The curing conditions for the cylinders were therefore very unfavorable for the development of normal strength, since the relatively small volume of concrete in proportion to the large surface area exposed to the dry air of the laboratory permitted a rapid drying of the concrete, which prevented the normal hydration of the cement. The moisture which had been absorbed by the forms and tiles surrounding the concrete in the beams probably had the effect of retarding the loss of moisture, and this, together with the smaller ratio of the exposed surface area to volume, created a more favorable curing condition for the concrete in the beams than for the control cylinders.

The strength of the concrete in the prisms was probably more nearly equal to the strength of the concrete in the beams than that in the cylinders. The forms for the prisms, like those for the beams, were not water-tight and, the materials of which the forms were made being the same as those which surrounded the concrete in the corresponding beams, had about the same porosity. Furthermore,

5 Abrams, " Effect of vibration, jigging, and pressure on fresh concrete," Proc. Amer. Concrete Inst., 15, 1919. Wig, Williams, and Gates, Strength and Other Properties of Concretes as Affected by Materials and Methods of Preparation. B. S. Tech. Paper, No. 58.

${ }^{6}$ Wig, Williams, and Gates, Strength and Other Properties of Concretes as Affected by Materials and Methods of Preparation. B. S. Tech. Paper No. 58. Abrams, Effect of Curing Condition on the Wear and Strength of Concrete, Bul. 2, Structural Materials Research Lab., Lewis Inst., Chicago. Abrams, Flexural Strength of Plain Concrete, Bul. 11, Structural Materials Research Lab., Lewis Inst., Chicago. Green, "Relation between methods of curing standard concrete test specimens and their comparative strength at 28 days," Proc. A. S. T. M., 19, Pt. II. Gonnerman, "Effect of age and condition of storage on the strength of concrete," Proc. Amer. Concrete Inst., 14, 1918. 
the ratio of the area of concrete directly exposed to the air to the rolume of concrete in the prisms, though greater than the ratio for the beams, was less than that for the cylinders. The effect of the absorption of some of the excess mixing water by the form material upon the strength of the concrete is dependent upon the rate at which the water is absorbed.

Some published ${ }^{7}$ and unpublished experiments made at the Bureau of Standards have shown that most of the water absorbed by burnedclay bodies similar in size and composition to hollow tiles will be absorbed in the first few minutes after immersion. Usually 60 to 70 per cent of the ultimate absorption will be taken up in 5 minutes and 70 to 80 per cent in 15 minutes. Although the conditions which exist in a form are quite different, it is evident that the tiles did absorb water rapidly. It is probable that most of the water absorbed by the tiles was taken up very soon after the concrete was placed, and therefore this absorption increased the strength of the concrete.

The difference in the shapes of the test specimens tended to cause a further difference in the strength of the prisms and cylinders. The ratio of length to least dimension for the cylinders was 2 and for the prisms 1.5. Some tests ${ }^{8}$ indicate that this would cause the prisms to resist stresses approximately 5 per cent greater than would the cylinders if the quality of the concrete were uniform.

The strength of the concrete, as indicated by the tests on the control specimens, differed greatly from week to week. Large differences in the strength of concrete which is made without a careful proportiong of the aggregate and amount of mixing water are not unusual. One cause was the lack of uniformity of the aggregate from week to week. Nearly all of the aggregate used on one day was taken from one delivery and for this reason was probably quite uniform. Although no tests were made of the aggregate, it was noticeable that the material used on January 11 was finer than that used on other days and that it contained a large amount of silty material. Another cause was the amount of mixing water used which not only differed from batch to batch but probably also from week to week.

No definite conclusions can be drawn concerning the average strength of the concrete in the beams. For the purpose of design it is commonly assumed that a $1: 2: 4 \mathrm{mix}$ will produce a concrete having an ultimate strength of $2,000 \mathrm{lbs} . / \mathrm{in}^{2}{ }^{2}$ when tested in the form of standard cylinders 28 days old, made, and stored under laboratory conditions, but it is known from numerous tests of field-

\footnotetext{
7 Foster, "Effectiveness of different methods of making absorption determinations," Jour, of the Amer. Ceramic Soc., 6, No. 5, 19:3.

${ }^{8}$ Report of Committee on Specifications and Methods of Tests for Concrete Materials. Proc. Amer. Concrete Inst., 10, 1914.
} 
made $1: 2: 4$ concrete that the strength is frequently, if not usually, much less than $2,000 \mathrm{lbs} . / \mathrm{in}^{2}{ }^{2}$

Taking into consideration the age of the test pieces and the storage conditions, it seems probable that the average strength of the concrete in the beams was within the range usually obtained in building construction.

\section{HOLLOW TILES}

Four different lots of tiles were used: (1) 3-cell 6 by 12 by 12 inch partition tiles made of Indiana surface clay, (2) 6-cell 8 by 12 by 12 inch load-bearing wall tiles made of Indiana surface clay, (3) 6 -cell 8 by 12 by 12 inch load-bearing wall tiles made of Ohio fire clay, (4) 6 -cell 8 by 12 by 12 inch load-bearing wall tiles made of Kentucky shale. The types of tiles are shown in Figure 5.

Ten tiles from each lot were selected by appearance and their physical properties determined. Each tile was loaded parallel to the direction of the cells and the modulus of elasticity and compressive strength determined. The deformations were measured over an 8-inch gauge length with a clamp type compressometer having a single micrometer dial reading to 0.0001 inch. The absorption was measured on three pieces containing from 12 to 20 square inches of face area taken from each tile after the compression test. These were first dried to constant weight, immersed in cold water, raised to the boiling point in one hour, and boiled for four hours. They were then permitted to cool to room temperature and weighed.

- The results of the tests of the tiles are given in Table 3. The deformations taken to within 70 per cent of the ultimate strength of the tile were proportional to the loads applied. Table 3 shows that the 3 -cell 6 by 12 by 12 inch Indiana surface clay tiles would be classed as "soft" according to the tentative specifications for hollow burned-clay partition tile C $56-24 \mathrm{~T}$ of the American Society for Testing Materials. The 6 -cell 8 by 12 by 12 inch Indiana surface clay tiles would be classed as "soft " according to the tentative specifications for hollow burned-clay load-bearing wall tile, C 34-24T, of the same society, and the 6 -cell 8 by 12 by 12 inch Ohio fire-clay tiles and the 6 -cell 8 by 12 by 12 inch Kentucky shale tiles would be classed as "hard" according to the same specification.

a Thompson and Nichols, discussion, "Compressive strength of concrete in flexure," Proc. Amer. Concrete Inst., 18, 1922. 
TABLE 3.-Compressive tests of the tiles

[Loads applied on open ends of tiles]

\begin{tabular}{|c|c|c|c|c|c|c|c|c|c|}
\hline \multirow[b]{2}{*}{ Hollow tiles } & \multirow{2}{*}{$\begin{array}{l}\text { Refcr- } \\
\text { ence } \\
\text { num- } \\
\text { ber }\end{array}$} & \multicolumn{2}{|c|}{ Thickness } & \multirow{2}{*}{$\begin{array}{c}\text { Total } \\
\text { weight }\end{array}$} & \multirow{2}{*}{$\begin{array}{l}\text { Weight } \\
\text { of } \\
\text { constit- } \\
\text { uent } \\
\text { mate- } \\
\text { rial }\end{array}$} & \multicolumn{2}{|c|}{$\begin{array}{l}\text { Compressive } \\
\text { strength }\end{array}$} & \multirow{2}{*}{$\begin{array}{l}\text { Ab- } \\
\text { sorp- } \\
\text { tion }\end{array}$} & \multirow{2}{*}{$\begin{array}{l}\text { Modulus } \\
\text { of } \\
\text { elasticity } \\
\text { (net area) }\end{array}$} \\
\hline & & $\begin{array}{l}\text { Ver- } \\
\text { tical } \\
\text { shell } \\
(s)\end{array}$ & $\begin{array}{l}\text { Ver- } \\
\text { tical } \\
\text { webb } \\
(w)\end{array}$ & & & $\begin{array}{c}\text { Gross } \\
\text { area }\end{array}$ & $\begin{array}{l}\text { Net } \\
\text { area }\end{array}$ & & \\
\hline \multirow[t]{2}{*}{$\begin{array}{l}\text { Lot No. 1, 3-cell } 6 \text { by } 12 \text { by } \\
12 \text { inch Indiana surface } \\
\text { clay. }\end{array}$} & \multirow[t]{2}{*}{$\begin{array}{r}1 \\
2 \\
3 \\
4 \\
5 \\
6 \\
7 \\
8 \\
9 \\
10\end{array}$} & $\begin{array}{c}\text { Inck } \\
0.80 \\
.80 \\
.80 \\
.77 \\
.81 \\
.80 \\
.81 \\
.81 \\
.81 \\
.81\end{array}$ & $\begin{array}{r}\text { Inch } \\
0.76 \\
.70 \\
.69 \\
.68 \\
.69 \\
.69 \\
.69 \\
.69 \\
.69 \\
.69\end{array}$ & $\begin{array}{r}\text { Lbs. } \\
21.7 \\
21.2 \\
21.2 \\
22.0 \\
20.8 \\
21.3 \\
21.0 \\
21.7 \\
21.0 \\
21.3\end{array}$ & $\begin{array}{c}\text { Lbs./in. } \\
0.0590 \\
.0581 \\
.0589 \\
.0628 \\
.0581 \\
.0590 \\
.0573 \\
.0590 \\
.0587 \\
.0587\end{array}$ & \begin{tabular}{|c} 
Lbs.Jin. \\
1.200 \\
890 \\
1.340 \\
1.400 \\
1.160 \\
1.350 \\
1.200 \\
1,180 \\
1,200 \\
1,200
\end{tabular} & $\begin{array}{c}L b s . / i n .{ }^{2} \\
2.760 \\
2,080 \\
3.150 \\
3.290 \\
2.700 \\
3.140 \\
2,780 \\
2,740 \\
2,800 \\
2,760\end{array}$ & \begin{tabular}{|r|} 
Per cent \\
24.7 \\
26.0 \\
26.0 \\
21.9 \\
26.2 \\
26.1 \\
27.9 \\
26.0 \\
25.6 \\
24.6
\end{tabular} & $\begin{array}{c}\text { Lbs./in. }{ }^{2} \\
1,820,000 \\
1,400.000 \\
1,640,000 \\
2,400,000 \\
1,470,000 \\
1,510,000 \\
1,690,000 \\
1,460,000 \\
1,510,000 \\
1,960,000\end{array}$ \\
\hline & & .80 & .70 & 21.3 & .0590 & 1,210 & 2,820 & 25.5 & $1,686,000$ \\
\hline $\begin{array}{l}\text { Lot No. } 2,6 \text {-cell } 8 \text { by } 12 \text { by } \\
12 \text { inch Indiana surface } \\
\text { clay. }\end{array}$ & \multirow[t]{2}{*}{$\begin{array}{r}1 \\
2 \\
3 \\
4 \\
5 \\
6 \\
7 \\
8 \\
9 \\
10\end{array}$} & $\begin{array}{l}.89 \\
.87 \\
.86 \\
.88 \\
.87 \\
.86 \\
.89 \\
.87 \\
.87 \\
.89\end{array}$ & $\begin{array}{l}.63 \\
.63 \\
.62 \\
.63 \\
.63 \\
.64 \\
.64 \\
.63 \\
.64 \\
.62\end{array}$ & $\begin{array}{l}31.0 \\
30.5 \\
30.3 \\
30.7 \\
29.5 \\
29.3 \\
31.0 \\
31.2 \\
30.5 \\
31.2\end{array}$ & $\begin{array}{l}.0610 \\
.0609 \\
.0609 \\
.0608 \\
.0590 \\
.0596 \\
.0604 \\
.0613 \\
.0611 \\
.0626\end{array}$ & $\begin{array}{l}1,630 \\
1,220 \\
1,310 \\
1,140 \\
1,090 \\
1,080 \\
1,270 \\
1,200 \\
1,270 \\
1,100\end{array}$ & $\begin{array}{l}3,690 \\
2,790 \\
2,980 \\
2,610 \\
2,500 \\
2,500 \\
2,870 \\
2,700 \\
2,930 \\
2,500\end{array}$ & $\begin{array}{l}23.2 \\
23.8 \\
24,2 \\
24.1 \\
25.9 \\
25.3 \\
24.7 \\
23.4 \\
24.1 \\
22.7\end{array}$ & $\begin{array}{l}1,950,000 \\
1,610,000 \\
2,000,000 \\
1,570,000 \\
1,510,000 \\
1,165,000 \\
1,490,000 \\
1,770,000 \\
1,450,000 \\
1,710,000\end{array}$ \\
\hline \multirow[b]{2}{*}{$\begin{array}{l}\text { Lot No. } 3,6 \text {-cell } 8 \text { by } 12 \\
\text { by } 12 \text { inch Ohio fire clay }\end{array}$} & & .88 & .63 & 30.5 & .0608 & 1,230 & 2,810 & 24.1 & $1,623,000$ \\
\hline & $\begin{array}{r}1 \\
2 \\
3 \\
4 \\
5 \\
6 \\
7 \\
8 \\
9 \\
10\end{array}$ & $\begin{array}{l}.78 \\
.76 \\
.77 \\
.77 \\
.75 \\
.75 \\
.76 \\
.77 \\
.79 \\
.77\end{array}$ & $\begin{array}{l}.59 \\
.61 \\
.60 \\
.60 \\
.59 \\
.59 \\
.61 \\
.60 \\
.59 \\
.59\end{array}$ & $\begin{array}{l}34.3 \\
34.7 \\
34.7 \\
34.5 \\
34.0 \\
34.3 \\
34.5 \\
35.5 \\
34.7 \\
34.3\end{array}$ & $\begin{array}{l}.0717 \\
.0748 \\
.0720 \\
.0722 \\
.0759 \\
.0739 \\
.0753 \\
.0746 \\
.0721 \\
.0755\end{array}$ & $\begin{array}{l}1,380 \\
1,720 \\
1,550 \\
1,710 \\
2,820 \\
1,950 \\
2,380 \\
1,690 \\
2,210 \\
2,300\end{array}$ & $\begin{array}{l}3,520 \\
4,500 \\
3,980 \\
4,350 \\
7,270 \\
5,020 \\
6,210 \\
4,300 \\
5,580 \\
5,820\end{array}$ & $\begin{array}{r}12.9 \\
12.6 \\
13.0 \\
12.4 \\
8.6 \\
11.2 \\
9.7 \\
10.2 \\
12.4 \\
11.4\end{array}$ & $\begin{array}{l}3,160,000 \\
3,510,000 \\
2,180,000 \\
2,600,000 \\
4,540,000 \\
4,040,000 \\
4,220,000 \\
5,250,000 \\
3,400,000 \\
3,440,000\end{array}$ \\
\hline \multirow[t]{2}{*}{ Average............ } & & .77 & .60 & 34.5 & .0738 & 1,970 & 5,050 & 11.4 & $3,634,000$ \\
\hline & $\begin{array}{r}1 \\
2 \\
3 \\
4 \\
5 \\
6 \\
7 \\
8 \\
9 \\
10\end{array}$ & $\begin{array}{l}.82 \\
.82 \\
.84 \\
.79 \\
.81 \\
.82 \\
.80 \\
.82 \\
.82 \\
.84\end{array}$ & $\begin{array}{l}.60 \\
.62 \\
.62 \\
.61 \\
.60 \\
.62 \\
.60 \\
.58 \\
.60 \\
.61\end{array}$ & $\begin{array}{l}37.0 \\
36.2 \\
36.7 \\
36.3 \\
37.2 \\
36.5 \\
36.3 \\
37.5 \\
37.0 \\
36.3\end{array}$ & $\begin{array}{l}.0790 \\
.0760 \\
.0756 \\
.0755 \\
.0810 \\
.0746 \\
.0770 \\
.0808 \\
.0811 \\
.0724\end{array}$ & $\begin{array}{l}2,120 \\
3,310 \\
1,540 \\
2,100 \\
2,970 \\
2,910 \\
2,490 \\
2,850 \\
3,000 \\
1,280\end{array}$ & $\begin{array}{l}5,020 \\
5,370 \\
3,560 \\
4,840 \\
7,150 \\
6,770 \\
5,850 \\
6,740 \\
7,110 \\
3,000\end{array}$ & $\begin{array}{r}6.8 \\
8.1 \\
9.8 \\
8.7 \\
7.8 \\
10.4 \\
9.5 \\
7.5 \\
6.2 \\
14.6\end{array}$ & $\begin{array}{l}5,340,000 \\
4,300,000 \\
3,500,000 \\
4,250,000 \\
5,060,000 \\
6,850,000 \\
5,900,000 \\
5,850,000 \\
6,000,000 \\
3,050,000\end{array}$ \\
\hline 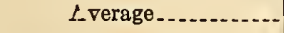 & & .82 & .61 & 36.7 & .0773 & 2,460 & 5,540 & 8.9 & $5,010,000$ \\
\hline
\end{tabular}

\section{METHOD OF TESTING BEAMS}

Before placing the beams in the testing machine they were measured, marked for the positions of the loads and supports, and the holes drilled in the concrete, tiles, and reinforcement, so that strain-gauge readings could be taken. The measurements included the total breadth of the beams, measured at intervals of 2 feet along their length, and the depth from the top of the concrete to the centers of the two outside reinforcing bars which had been exposed for strain-gauge measurements. The locations of the 8-inch gauge 
lines on which strain measurements in the concrete, tiles, and steel were made are shown in Figure 1.

The beams were tested in a vertical screw universal testing machine having a capacity of 600,000 pounds. The moving head of the machine applied its force through a spherical bearing to a loading beam as shown in Figure 6. At the lines of the loads and supports steel plates 8 inches wide and 1 inch thick and extending the full breadth of the beams were embedded in plaster of Paris in order to distribute the pressure uniformly. The long beams

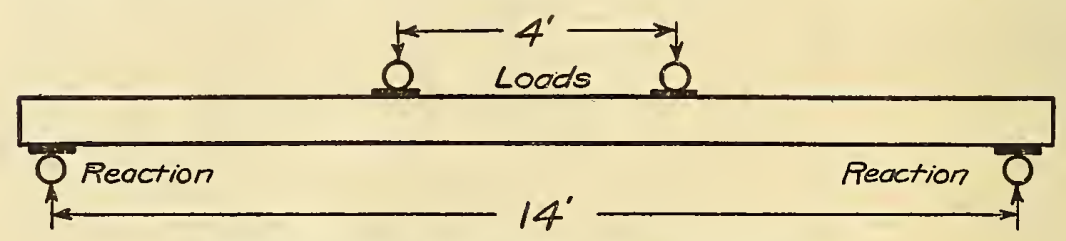

A. BEND TEST FOR LONG BEAMS

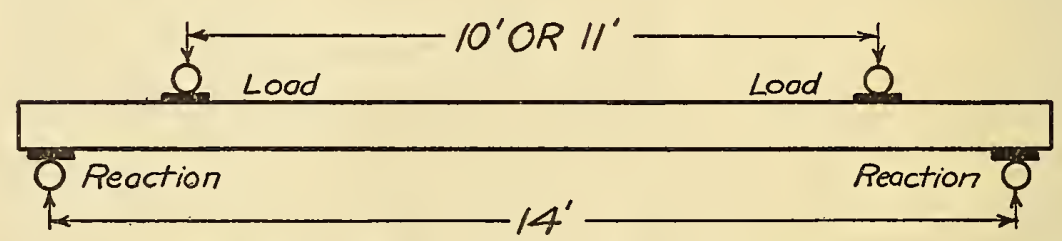

B.SHEAR TEST FOR LONG BEAMS

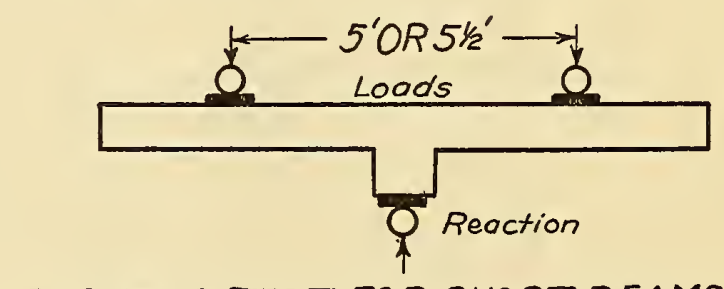

C. SHEAR TEST FOR SHORT BEAMS

Fig. 7.-Loading diagram for test beams

were supported with a span of 14 feet (fig. $7 A B$ ). The short beams were supported on the concrete blocks which represented the stems of supporting girders (fig. $7 C$ ).

The testing of the long beams was divided into two stages. The object of the first test was to cause high bending stresses and of the second test to develop high shearing stresses. Accordingly, the loads for the first test were spaced 2 feet each side of the centers of the beams (fig. $7 \mathrm{~A}$ ) and for the second test were placed from $11 / 2$ to 2 feet from the nearest supports, as shown in Figure $7 B$. Figure 6 shows the set-up for the shear test. The short beams were 
Technologic Papers of the Bureau of Standards, Vol. 19

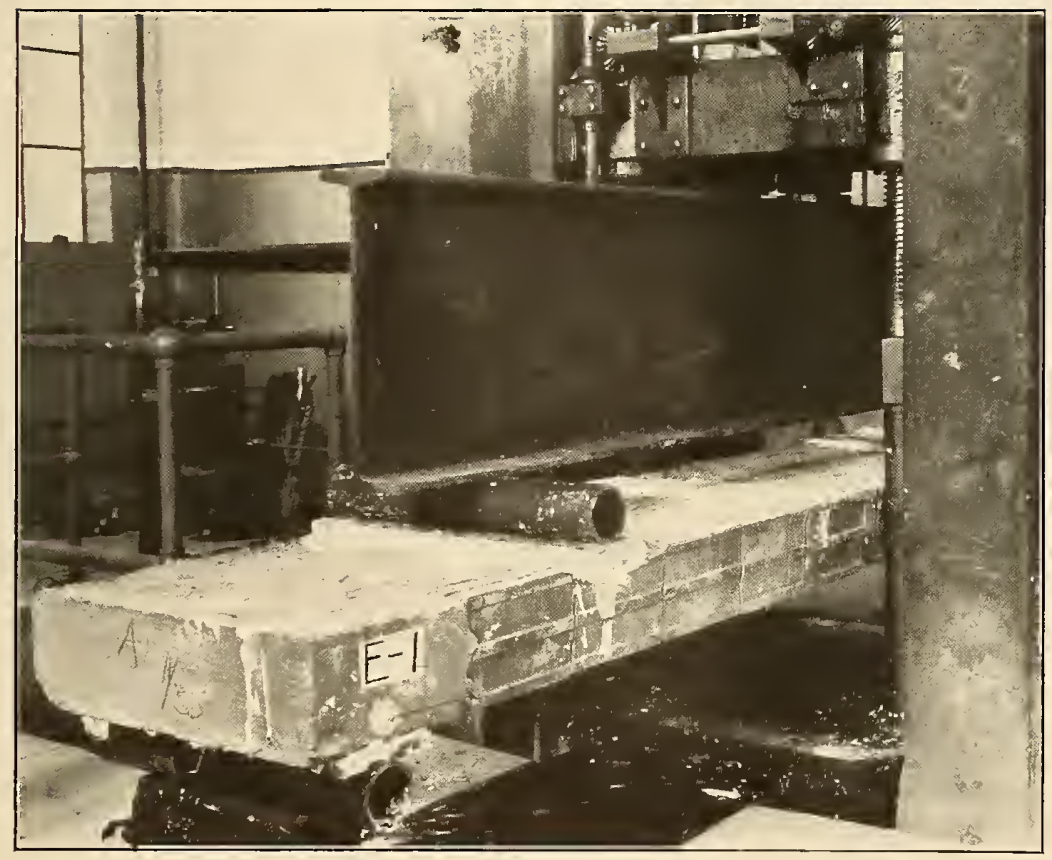

Fig. 6.-Beam E-1 in the testing machine for shear test 
loaded continuously to failure, the loads being applied either at 2.5 or at 2.75 feet from the centers of the beams, as shown in Figure $7 C$.

In loading the long beams, to produce high-bending stresses, it was desired that the maximum loads applied be as near the maximum, as determined by the ultimate strength of the construction in flexure, as could be without injuring the beams to such an extent as to make them unfit for the shear tests. An 8-inch strain gauge was clamped on each of the two outside reinforcing bars to measure their deformations. A strain gauge was also used to measure the compressive deformations in the concrete and tiles. The deflection was measured at the centers of the beams on mirror scales graduated to 0.1 inch, by means of a fine wire supported directly over the supports and kept taut by rubber bands as shown in Figure 6 . Before a load was applied on a beam a set of zero observations was taken on all gauge lines and the center deflection read. An increment of load was then applied and a second series of observations taken. The amount of each load increment was chosen so as to secure at least five series of observations for each beam before failure. During the test cracks were noted as they became visible. The loading was continued until the strain-gauge readings indicated that either the steel had been stressed well beyond the yield point or the deformation in the concrete was near the amount which may be expected in a compression failure of a beam.

The loads were then applied nearer the supports for the shear test. The position of the loads and span between the supports are given in Table 6 and shown in Figure 7.

The deformations and deflection readings and the record of the cracks were taken on the short beams in the same manner as on the long beams. On account of the manner of loading there was no length over which the bending moment was constant. The gange lines were located as near to the centers of the beams as the location of the concrete blocks and the necessary clearances for the apparatus would permit, and their positions with respect to the centers of the beams were recorded. These readings made it possible to distinguish between failures due to the yielding of the tension reinforcement and those directly due to compression failure of the concrete and tiles.

\section{RESULTS OF TESTS AND DISCUSSION}

\section{r. GENERAL BEHAVIOR OF BEAMS DURING TESTS}

The behavior of the combination beams during the tests was similar to that of the concrete beams. The shapes of the load-deformation curves and the load-deflection curves shown in Figures 8, 9, 10, $43356^{\circ}-25-3$ 
and 11 do not differ materially from those which have been obtained from tests made on concrete beams having about the same ratio of reinforcement. The chief difference noted was that the maximum average compressive deformation over an 8-inch gauge length in the concrete of the combination beams without topping immediately preceding a compression failure was less than in the concrete beams. The load-deformation curves for the tiles were similar in shape to corresponding curves for the adjacent concrete.

Tension cracks across the bottom of the beams were visible in the tiles at the same time that they could be seen in the concrete. These cracks formed an irregular but continuous line across the beam without changes in the directions of the cracks where the concrete and tiles joined. No tendency for the cracks to follow the joints between the tiles.could be observed.

Diagonal cracks which appeared in the outside tiles of some of the beams were found, after breaking the beam, to be in approximately the same plane and to have about the same length as opposite cracks in the concrete. The joints between the tiles did not appear to change the direction or affect the development of diagonal cracks.

The bond between the concrete and tiles was sufficient to resist the tendency of the tiles to break away from the concrete until after failure of the beams had occurred from some other cause.

Since the loads were applied by a testing machine, it was possible to watch the progress of the compression failures by observing the deformation and spalling of the concrete and tiles. In the beams which failed in compression the failure of the concrete and tiles seemed to occur simultaneously.

In the beams with open joints between the tiles there must have been a concentration of stress in a portion of the concrete opposite the joints. Even though the staggered joints aided in relieving this, the stress in a small volume of concrete adjacent to a joint was probably much greater than the average stress in the concrete within the gauge length. It may even have been higher than would have caused failure in a solid concrete beam, since these highly stressed portions were surrounded and supported by a relatively large volume carrying lower stresses. Evidence of similar action is found in records of tests of beams and compression members. Beams which fail in compression do not fail until the strain in the concrete is greater than would cause the failure of a compression test specimen of usual dimensions. Tests show that when a load is applied to a relatively small portion of a concrete surface higher stresses will be resisted than when the entire surface is loaded. ${ }^{10}$ It seems probable

10 Taylor and Thompson, "Concrete plain and reinforced," 1916, p. 330. 
that very high stresses could and probably did occur in small volumes of the concrete opposite joints without causing failure of the combination beams. It is, however, probably due to these concentrated stresses that the average compressive strains observed in the
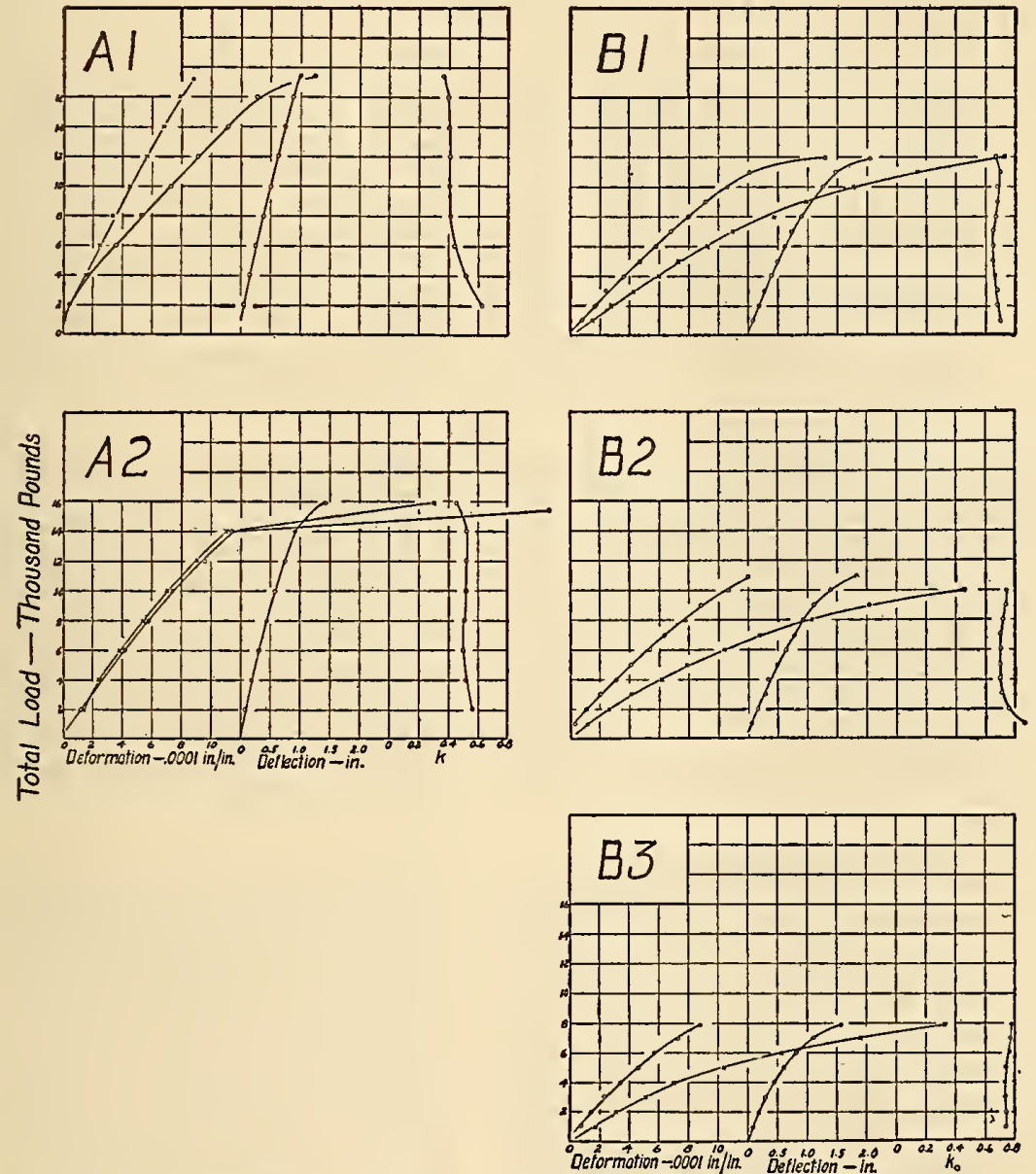

FIg. 8.-Load.deformation curves for concrete and steel, load-deflection curves, and values of ko for the long beams $A$ and $B$

The elongations in the reinforcement are shown by circles and the compressions in the concrete by crosses.

concrete of the combination beams were never as great as in the solid concrete beams.

\section{FLEXURAL TESTS ON LONG BEAMS}

(a) EXPERIMENTAL DATA, METHODS OF COMPUTATION AND NOTATION

The load-deformation curves for the concrete and steel, the loaddeflection curve, and the proportional depth of neutral axis are shown for each of the long beams in Figures 8, 9, 10, and 11. The 
deformations in the concrete and reinforcement for beams C, D, E, $\mathrm{F}$, and $\mathrm{G}$ were determined from the strain-gauge readings taken on but one gauge line on each material, and the deformations shown for beams $\mathrm{A}, \mathrm{B}$, and $\mathrm{H}$ are the average of measurements taken on two gauge lines of each material. The deformations given are
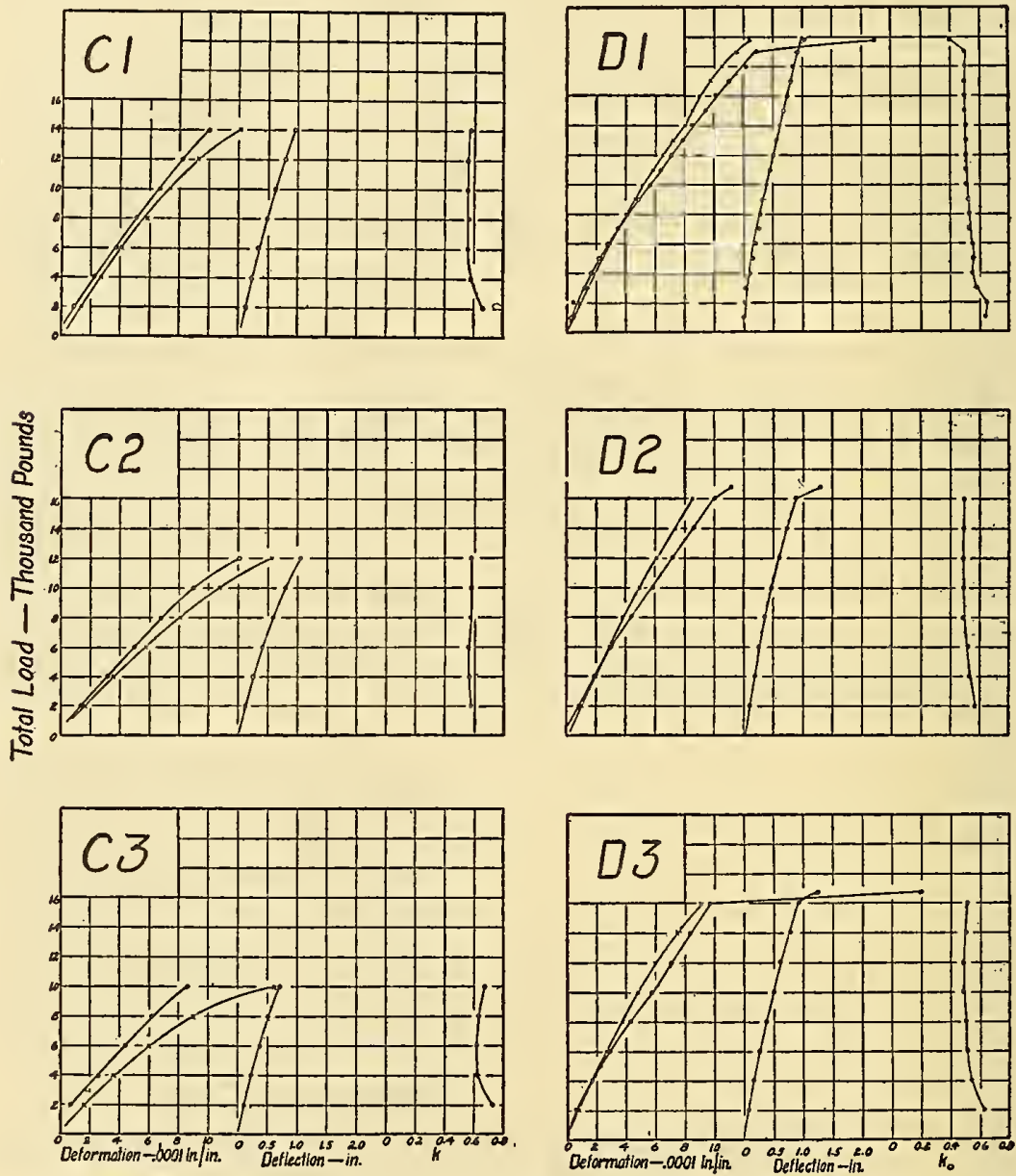

FIG. 9.-Load-deformation curves for concrete and steel, load-deflection curves, and values of $k$ o for the long beams $C$ and $D$

The elongations in the reinforcement are shown by circles and the compressions in the concrete by crosses.

those measured in the concrete at the extreme fiber and in the steel at the bottom of the bars. Each point on the load-deflection curves is the average of the two measurements taken, one on each side of the beam. In the same figures are given the experimentally determined depth of the neutral axis expressed as a fraction $k_{0}$ of the dis- 
tance $d$ from the compression surface of the beam to the center of the reinforcement. These were calculated from the deformations on the assumption of a linear distribution of strain over the cross section.

Tables 4 and 5 summarize the data of the bend tests on the long
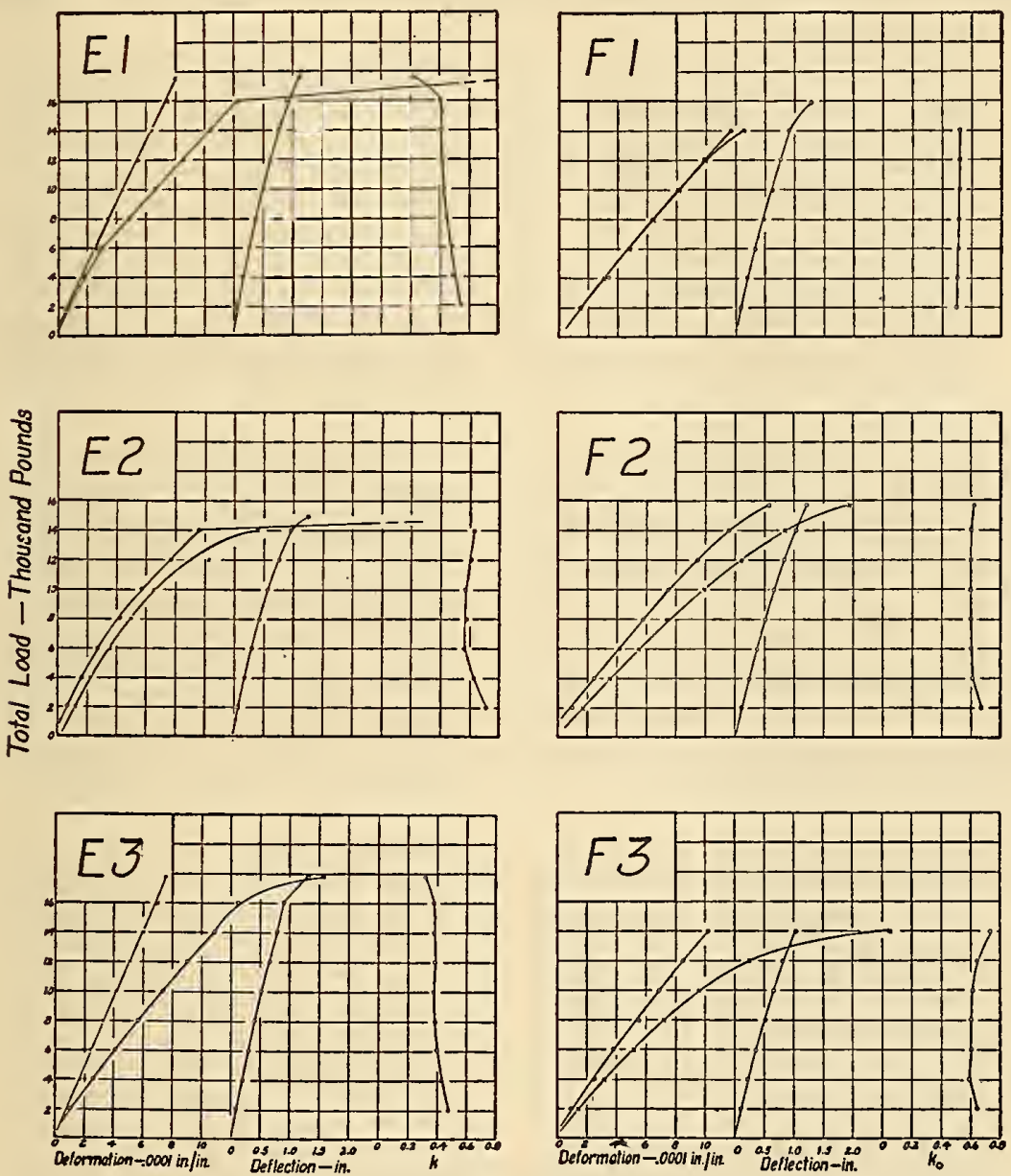

Fig. 10.-Load-deformation curves for concrete and steel, load-deflection curves, and values of to for the long beams $E$ and $F$

The elongations in the reinforcement are shown by circles and the compressions in the concrete by crosses.

beams. In Table 4 are given the construction data for the beams and a comparison of observed stresses and strains at loads below the maximum, with corresponding values computed from certain empirical assumptions. The values given correspond to three different loads, marked in the table as numbers 1,2 , and 3. 
1. It was desired to study the behavior of the beams under conditions corresponding as nearly as possible to the conditions under the usual design loads. For this reason load number 1 was chosen from the test loads by selecting the load which gave $(a)$ an average tensile strain in the steel greater than 0.00017 inch per inch. This
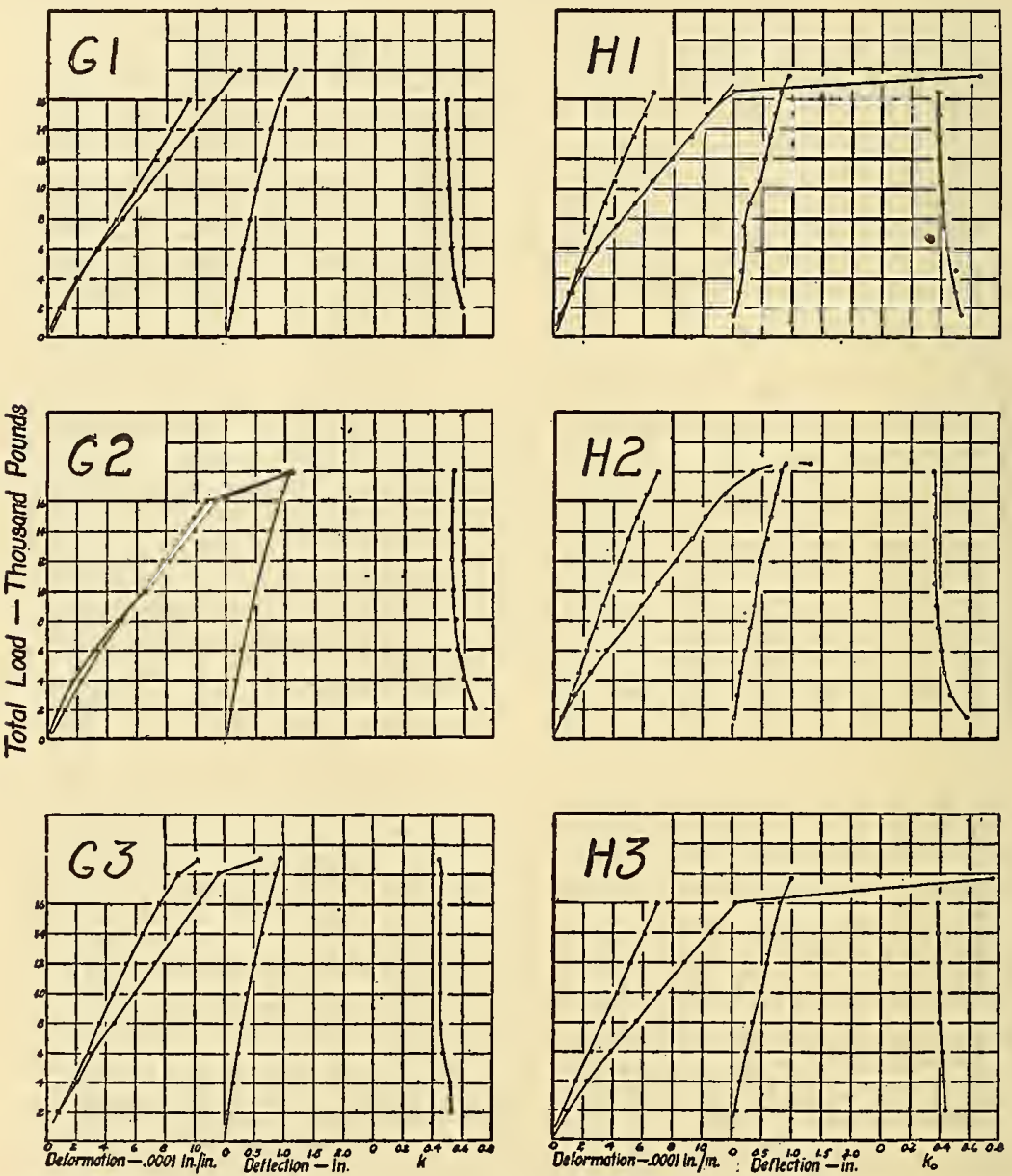

FIG. 11.-Load-deformation curves for concrete and steel, load-deflection curves, and values of $k$ ofor the long beams $G$ and $H$

The elongations in the reinforcement are shown by circles and the compressions in the concrete by crosses.

insured that the concrete below the neutral axis was cracked as is usually assumed in design, and $(b)$ an average compressive strain in the concrete less than 0.0004 inch per inch. On a modulus of $2,000,000 \mathrm{lbs} . / \mathrm{in}^{2}{ }^{2}$ this would give a stress less than $800 \mathrm{lbs} . / \mathrm{in}^{2}{ }^{2}$

2. Load number 2 was interpolated from the load-deformation curves to give an average tensile strain in the steel of 0.00055 inch 
per inch, corresponding on the basis of a modulus of $29,000,000$ lbs./in. ${ }^{2}$, to the usual design stress of $16,000 \mathrm{lbs} . / \mathrm{in}^{2}$

3. Load number 3 was similarly interpolated to give a measured deformation in the steel of 0.0011 inch per inch corresponding to a stress of $32,000 \mathrm{lbs}$./in. ${ }^{2}$, double the usual design stress.

All computations were based upon the usual assumptions for reinforced concrete beams. These are as follows:

1. A plane section before bending remains plane after bending.

2. Adhesion between the concrete and steel is perfect.

3. In calculating the resisting moment the tensile resistance of the concrete is neglected.

4. The modulus of elasticity of concrete in compression as well as that of the steel in tension is constant. The distribution of compressive stress is therefore rectilinear.

The notation and formulas used in analyzing the test results are based upon the notation and formulas used in the 1924 report of the Joint Committee on Standard Specifications for Concrete and Reinforced Concrete, ${ }^{11}$ with modifications made necessary by the addition of the tiles. The units employed in the notation and calculations are inches and pounds.

In that report the subscript $\mathrm{c}$ refers to concrete and ${ }_{\mathrm{s}}$ to steel. To these is added $\mathrm{t}$ for the tiles. Thus, $E_{\mathrm{c}} E_{\mathrm{s}}$, and $E_{\mathrm{t}}$ equal modulus of elasticity of concrete, steel, and tile, respectively.

In comparing the observations with the computations on different assumptions, the subscript owas used to represent results computed directly from deformations observed during the test. Thus $f_{\mathrm{so}}=E_{\mathrm{s}} e_{\mathrm{so}}$ is the tensile stress in the longitudinal reinforcement computed from the observed elongation $e_{\mathrm{so}}$.

In studying the effects of the tiles a distinction has to be made between the increased stiffness of the structure which is determined by the relations between the deformations and loads and the increased strength of the strucure which is determined by the moments which produced failure.

The subscript $\left({ }_{a}\right)$ is used to represent values modified empirically to take account of the presence of the tiles in the combination beams in determining stiffness relations; that is, corresponding to deformations and loads below the maximum.

Similarly, the subscript $(m)$ is used to represent values modified empirically to take account of the presence of the tiles in increasing the strength of the structure; that is, for computations using the loads which produced failure.

The symbols employed are collected for convenience of reference. Those marked with an asterisk are identical in meaning with the

${ }^{11}$ Report of the Joint Commtitee on Standard Specifications for Concrete and Reinforced Concrete (1924), Proc. Amer. Soc. for Testing Materials, 24, 1924. 


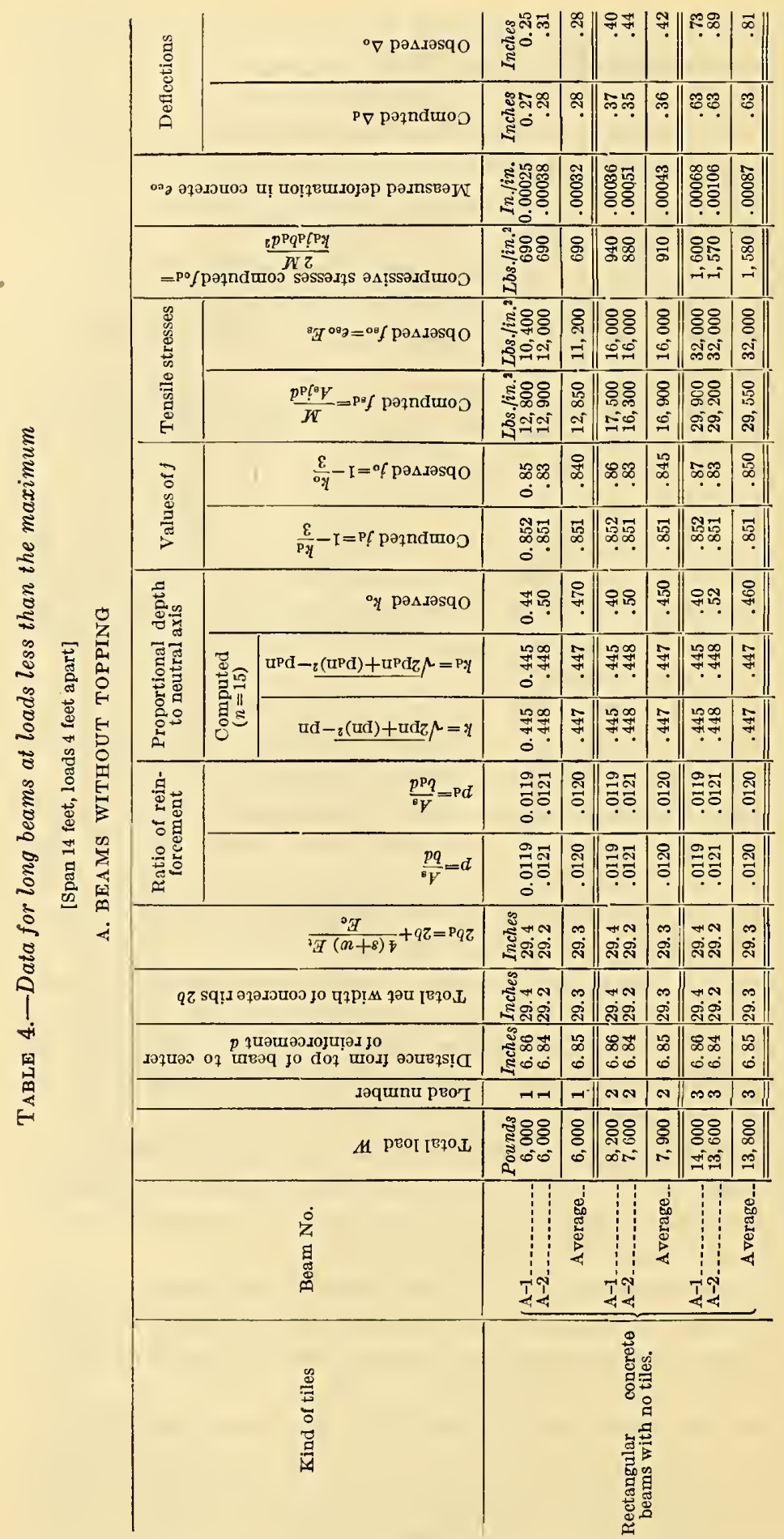




\begin{tabular}{|c|c|c|c|c|c|c|c|c|c|c|c|c|c|c|c|}
\hline 58 & $\approx$ & מ.ำ & 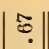 & NO & జฺฺ & | & | & 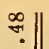 & $8 \%$ & $\because \simeq \stackrel{0}{\because}$ & $\div$ & 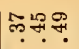 & 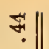 & ๑న్ & 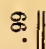 \\
\hline & $\stackrel{\infty}{?}$ & 육규유 & প্. & 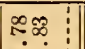 & సีลูి & เ & 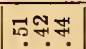 & का. & $5 ?$ & - & $\because$ & सुำ & $\dddot{1}$ & 요 & $\bar{\infty}$ \\
\hline 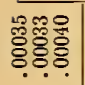 & \begin{tabular}{|l||}
0 \\
0 \\
$\vdots$ \\
0
\end{tabular} & 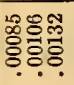 & \begin{tabular}{|l|} 
\\
0 \\
0 \\
0
\end{tabular} & 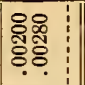 & 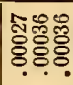 & 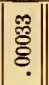 & 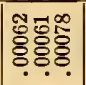 & \begin{tabular}{l||} 
\\
$\overline{0}$ \\
0
\end{tabular} & 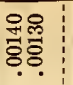 & 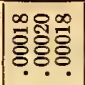 & 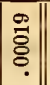 & 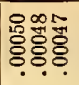 & 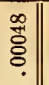 & 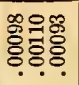 & $\left|\begin{array}{|l|} \\
\vdots \\
\vdots \\
\vdots\end{array}\right|$ \\
\hline ర్లిన్సి & \% & 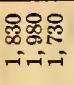 & 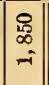 & 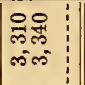 & జ & $\mid$\begin{tabular}{|l||} 
\\
$\infty$
\end{tabular} & 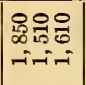 & \begin{tabular}{l||}
8 \\
- \\
-1
\end{tabular} & 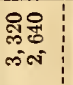 & 암융용 & 8 & 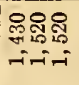 & 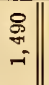 & 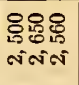 & 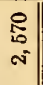 \\
\hline 88:8 & 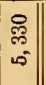 & $\begin{array}{l}880 \\
808 \\
605 \\
015\end{array}$ & \begin{tabular}{|l||} 
\\
8 \\
0 \\
-1
\end{tabular} & 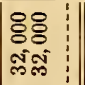 & 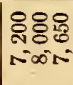 & \begin{tabular}{l||}
$\mathscr{8}$ \\
0 \\
$-=$
\end{tabular} & 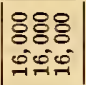 & \begin{tabular}{l||}
8 \\
0 \\
0 \\
0
\end{tabular} & 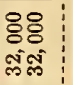 & 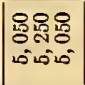 & $\mid$\begin{tabular}{c||}
$\stackrel{\Xi}{a}$ \\
$-5^{\circ}$
\end{tabular} & 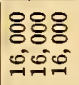 & 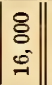 & 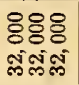 & 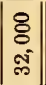 \\
\hline క్రి: & $\left|\begin{array}{|c|}8 \\
8 \\
10\end{array}\right|$ & 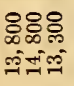 & 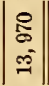 & 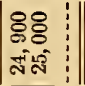 & 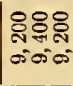 & 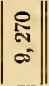 & 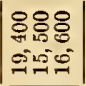 & $\mid$\begin{tabular}{|l||}
0 \\
8 \\
$=5$ \\
$=$
\end{tabular} & 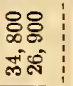 & 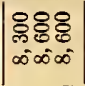 & \begin{tabular}{|l||}
8 \\
$a_{0}$ \\
$\infty^{\circ}$
\end{tabular} & 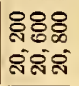 & 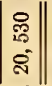 & 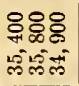 & 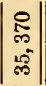 \\
\hline & $\mid$ & ำ? & ? & $\Re ?$ & $\infty-\infty ?$ & 电|| & б. & 怘|| & $\vec{\infty}$. & 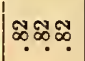 & $\left|\begin{array}{l|}\approx \\
\infty\end{array}\right|$ & ஐが & 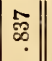 & œळ & 氾 \\
\hline$\sum$ 용 & 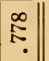 & 츄요 & 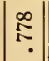 & 톡. & 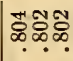 & \begin{tabular}{|c||}
\multirow{2}{*}{} \\
.
\end{tabular} & 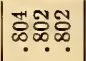 & 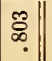 & 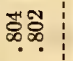 & 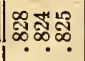 & $\left|\begin{array}{l|}\infty \\
\infty \\
\infty\end{array}\right|$ & 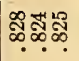 & 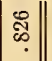 & 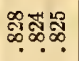 & \begin{tabular}{|l|} 
\\
0 \\
0
\end{tabular} \\
\hline ぜが & : & 4ㅇํㅇำ & 움 & 我 & 官 & 适| & 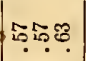 & 总|| & 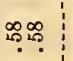 & | & 윰|| & 솜유ㅇㅠㅠ & 8 & 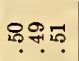 & \begin{tabular}{|l|}
8 \\
2
\end{tabular} \\
\hline 0 & \% & :0\%: & \begin{tabular}{|l|} 
\\
\end{tabular} & 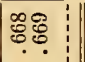 & | & \begin{tabular}{|l||}
$\overrightarrow{5}$ \\
\hdashline \\
\hdashline
\end{tabular} & 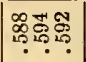 & 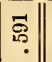 & 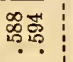 & 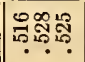 & 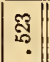 & 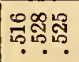 & 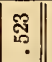 & 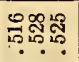 & 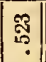 \\
\hline : & 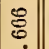 & : & 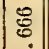 & : & 굽. & 동 & 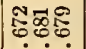 & 战 & 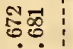 & : & 芯 & : & 范 & : & $\overline{8}$ \\
\hline 8 & क्ष & 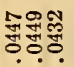 & 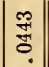 & 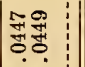 & 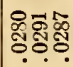 & 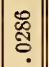 & 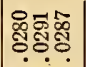 & 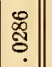 & 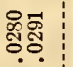 & 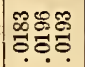 & \begin{tabular}{|l||} 
\\
$\vec{b}$ \\
.
\end{tabular} & 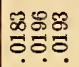 & \begin{tabular}{|l|}
\multicolumn{5}{|c|}{} \\
$\sigma$ \\
\end{tabular} & 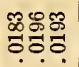 & \begin{tabular}{|l|}
$\vec{a}$ \\
$\vdots$ \\
\end{tabular} \\
\hline 8 & क्ञ & 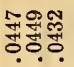 & 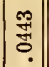 & 웧웡 & 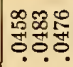 & 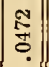 & 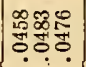 & 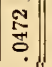 & 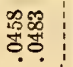 & 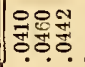 & 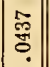 & 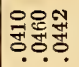 & 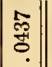 & 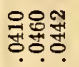 & 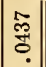 \\
\hline$\infty_{\infty}^{\circ} \infty^{\circ}$ & $\mid$ & $\begin{array}{c}7 \rightarrow 0 \\
\infty x^{\circ} \infty \infty^{\circ}\end{array}$ & $\left|\begin{array}{c}5 \\
0 \\
\infty\end{array}\right|$ & 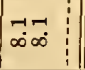 & 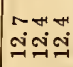 & $\left|\begin{array}{c}0 \\
0 \\
\right.$\cline { 1 - 1 } \\
\cline { 1 - 1 }\end{array}$|$ & 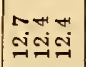 & 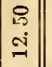 & 표 & 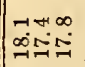 & \begin{tabular}{|l||}
$\hat{N}$ \\
\end{tabular} & 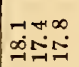 & 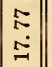 & $\begin{array}{l}-\infty \\
0 \\
0=0\end{array}$ & 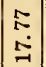 \\
\hline$\infty \infty$ & $\left|\begin{array}{c||}5 \\
0 \\
\infty\end{array}\right|$ & $\begin{array}{l}\rightarrow \rightarrow 0 \\
\infty \rightarrow \infty \infty^{\circ} \infty\end{array}$ & $\left|\begin{array}{c}5 \\
\infty \\
\infty\end{array}\right|$ & 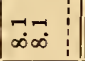 & 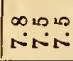 & $\left|\begin{array}{c}8 \\
0\end{array}\right|$ & 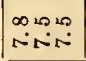 & $\left|\begin{array}{|l||}\stackrel{0}{0} \\
-1\end{array}\right|$ & 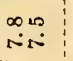 & 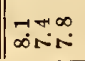 & $\begin{array}{l}\stackrel{1}{N} \\
\therefore\end{array}$ & $\mid \begin{array}{l}-1+\infty \\
\infty\end{array}$ & 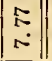 & $\begin{array}{l}-\infty+\infty \\
\infty \\
\infty\end{array}$ & $\begin{array}{l}\hat{N} \\
亡\end{array}$ \\
\hline $\begin{array}{l}880 \\
\dot{8}: 0 \\
\dot{0} 00\end{array}$ & $\left|\begin{array}{l}0 \\
0 \\
0\end{array}\right|$ & $\begin{array}{l}890 \\
\vdots 00 \\
000\end{array}$ & $\left|\begin{array}{l}0 \\
0 \\
0\end{array}\right|$ & $\mid \begin{array}{l}8 \% \\
0 \% 0 \\
00\end{array}$ & $\begin{array}{ll}1000 \\
000 \\
000\end{array}$ & $\mid$\begin{tabular}{|l|}
$\mathbb{N}$ \\
$\vdots$ \\
0
\end{tabular} & $\mid \begin{array}{ll}280 \\
0.80 \\
000\end{array}$ & $\left|\begin{array}{c}\mathfrak{N} \\
0 \\
0\end{array}\right|$ & $\begin{array}{l}198 \\
10.8 \\
0.0\end{array}$ & $\mid \begin{array}{l}\text { as? } \\
\text { Nasin }\end{array}$ & $\left|\begin{array}{l||}-1 \\
i\end{array}\right|$ & 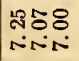 & $\underset{7}{\stackrel{7}{2}}$ & 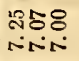 & $\mid \begin{array}{l}= \\
\vdots\end{array}$ \\
\hline$=1$ & -1 & NNN & $|\mathbf{n}|$ & $1 \infty \infty$ & $\mid \rightarrow-\pi$ & $|-1|$ & NN & $|\sim| \mid$ & m) & 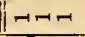 & $|-1|$ & INNN & |N & লm & $\infty$ \\
\hline 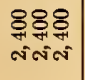 & 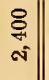 & 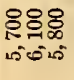 & $\mid$\begin{tabular}{l|}
8 \\
$\infty$ \\
15 \\
45
\end{tabular} & 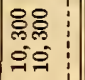 & |ి\%ి & $\left|\begin{array}{c||}\AA \\
-i\end{array}\right|$ & 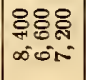 & $\mid$\begin{tabular}{|c||}
8 \\
$\vdots$ \\
$-=$
\end{tabular} & 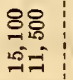 & $\begin{array}{l}8888 \\
\text { भiज゙ }\end{array}$ & $\begin{array}{c}8 \\
8 \\
+\end{array}$ & 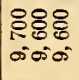 & \begin{tabular}{|l|}
8 \\
0 \\
0 \\
00
\end{tabular} & 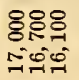 & 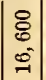 \\
\hline 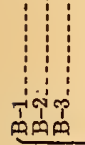 & 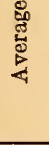 & क्रिक & 总 & 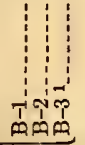 & $\begin{array}{r}0 \\
000 \\
0 \\
0\end{array}$ & 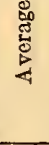 & $\begin{array}{r} \\
\text { Jง } \\
\text { ơo }\end{array}$ & 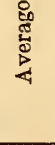 & 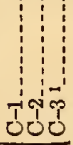 & 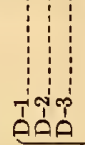 & 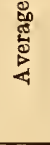 & $\begin{array}{r} \\
\text { เค่ }\end{array}$ & 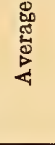 & 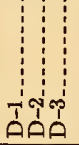 & 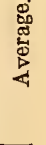 \\
\hline & & 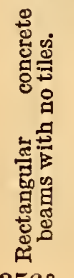 & & & & & 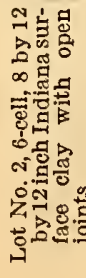 & & & & & 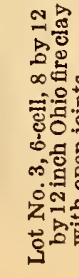 & & & \\
\hline
\end{tabular}




\begin{tabular}{|c|c|c|c|c|c|c|c|c|c|}
\hline & \multirow{2}{*}{ 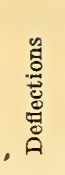 } & \multicolumn{2}{|r|}{${ }^{\circ} \nabla$ рәслаsqо } & 总 & $\approx \|$ & 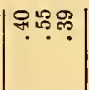 & | & ( & $\infty$ \\
\hline & & & 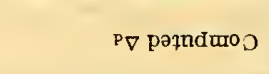 & 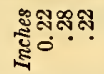 & ث. & 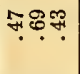 & : & $\underset{i-\infty}{\infty 8 . \infty}$ & 尔. \\
\hline \multirow{4}{*}{\multicolumn{2}{|c|}{ 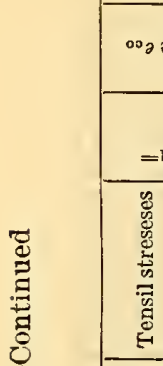 }} & & & 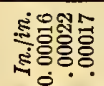 & $\mid$ & 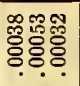 & Fi & 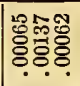 & \begin{tabular}{|l||} 
\\
0 \\
0 \\
$\vdots$ \\
\end{tabular} \\
\hline & \multicolumn{3}{|c|}{ 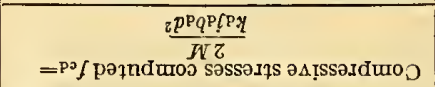 } & 홍유윰영 & 8 & $\begin{array}{l}\text { 영요 } \\
\text { rit-i-i }\end{array}$ & 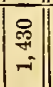 & 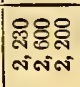 & oil \\
\hline & & \multicolumn{2}{|r|}{ 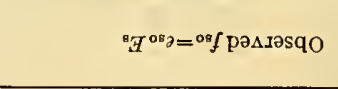 } & 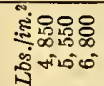 & $\mid$ & $\begin{array}{l}88 \\
88.8 \\
095\end{array}$ & 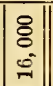 & 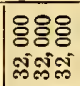 & \begin{tabular}{|c||} 
\\
$\vdots$ \\
0 \\
0
\end{tabular} \mid \\
\hline & & \multicolumn{2}{|r|}{ 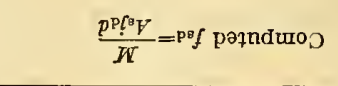 } & 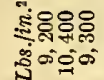 & \begin{tabular}{|c||}
0 \\
0 \\
0 \\
$\infty$
\end{tabular} & 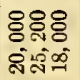 & $\left|\begin{array}{c}0 \\
0 \\
-1 \\
-4\end{array}\right|$ & 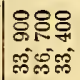 & \begin{tabular}{l|l|l}
$\mathscr{m}$ \\
$\tilde{m}^{0}$ \\
$\vec{\varpi}^{0}$
\end{tabular} \\
\hline \multirow{5}{*}{\multicolumn{2}{|c|}{ 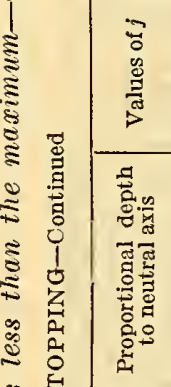 }} & \multicolumn{2}{|r|}{$\frac{\varepsilon}{\circ y}-I={ }^{\circ} \varrho$ pəa pəəsqo } & 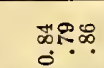 & 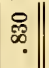 & 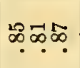 & $\left|\begin{array}{c}\infty \\
\infty \\
\infty \\
\infty\end{array}\right|$ & 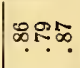 & 席. \\
\hline & & \multicolumn{2}{|r|}{ 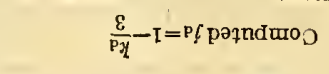 } & 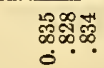 & 粂 & 品范 & \begin{tabular}{|l||}
$\mid \mathscr{q}$ \\
$\mathscr{8}$
\end{tabular} & $\begin{array}{ll}\infty \\
\infty \\
\infty \\
\infty\end{array}$ & $\mathscr{D}_{\infty}^{0}$ \\
\hline & & \multicolumn{2}{|r|}{ 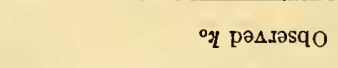 } & अ융 & 훙 & स艹 & $\mid$ & ऩฺ & 䇣 \\
\hline & & \multirow{2}{*}{ 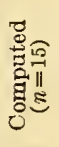 } & $\mathrm{UPd}-\underline{z(\mathrm{UPd})+\pi \mathrm{Pd} z} \mu=\mathrm{P}_{\mathrm{Y}}$ & 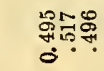 & 禺 & | & 电 & 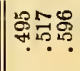 & 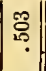 \\
\hline & & & $\mathrm{ad}-\underline{z}(\mathrm{ud})+\mathrm{ad} z \mu=y$ & 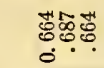 & 赵 & 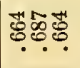 & $\left|\begin{array}{c}\mathbb{9} \\
6\end{array}\right|$ & 免范范 & 缶 \\
\hline \multirow{4}{*}{ 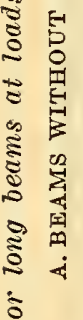 } & \multirow{2}{*}{ 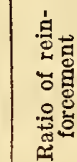 } & & $\frac{p P q}{\vec{P}_{V}}=P d$ & 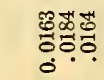 & 옹 & 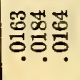 & $\left|\begin{array}{l||}0 \\
0 \\
0\end{array}\right|$ & 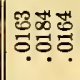 & $\left|\begin{array}{l}R \\
5 \\
\end{array}\right|$ \\
\hline & & & $\frac{p q}{{ }^{\frac{p}{V}}=d}$ & 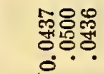 & $\mid$ & 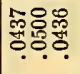 & $\left|\begin{array}{l}\infty \\
\substack{0 \\
\hdashline \\
0 \\
0}\end{array}\right|$ & 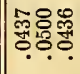 & 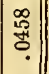 \\
\hline & \multicolumn{3}{|r|}{$\frac{O Q G}{q(a+s) \eta}+q Z=P Q Z$} & 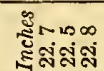 & $\begin{array}{l}\tilde{0} \\
\text { वูं }\end{array}$ & 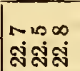 & 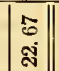 & 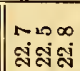 & 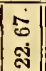 \\
\hline & \multicolumn{3}{|c|}{ 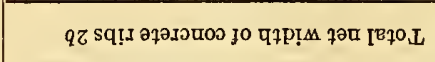 } & 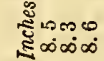 & $\mid \begin{array}{l}5 \\
\infty \\
\infty\end{array}$ & 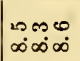 & $\left|\begin{array}{c}\hat{y} \\
\infty\end{array}\right|$ & $\| \begin{array}{l}\lim _{\infty} \infty \\
\infty \infty \infty \infty\end{array}$ & $\begin{array}{c}\overrightarrow{+} \\
\infty \\
\infty\end{array}$ \\
\hline & \multicolumn{3}{|c|}{ 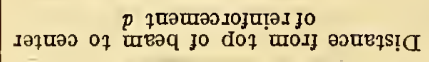 } & 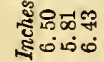 & $\left|\begin{array}{c}\stackrel{2}{2} \\
\vdots \\
0\end{array}\right|$ & 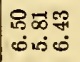 & $\left|\begin{array}{l}a \\
a \\
0 \\
0\end{array}\right|$ & 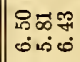 & \begin{tabular}{|l|l|}
\multirow{2}{*}{} \\
0 \\
0
\end{tabular} \\
\hline & & & səqunu рвот & नात्त & $\mid \rightarrow$ & NNN & $\propto$ & $\| \operatorname{sen}$ & $\infty$ \\
\hline & \multicolumn{3}{|r|}{ 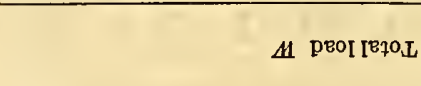 } & 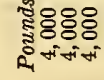 & $\left|\begin{array}{c}8 \\
8 \\
\operatorname{ti}^{-}\end{array}\right|$ & 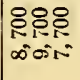 & $\left|\begin{array}{c}2 \\
\vdots \\
\infty\end{array}\right|$ & 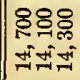 & $\left|\begin{array}{c}R \\
\infty \\
\mathbb{N}^{*}\end{array}\right|$ \\
\hline & \multicolumn{3}{|r|}{ 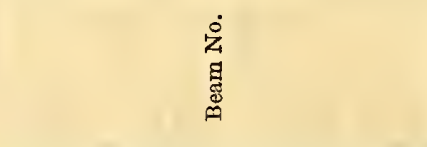 } & Fipe & 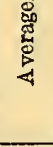 & & $\begin{array}{l}\text { 品 } \\
\text { 荧 } \\
\text { 营 }\end{array}$ & 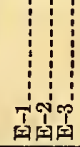 & 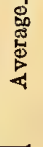 \\
\hline & \multicolumn{3}{|r|}{ 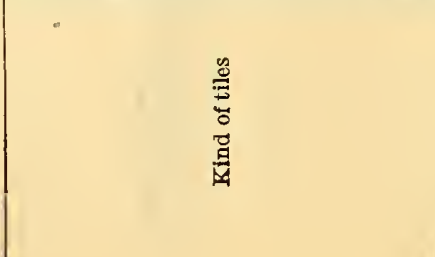 } & \multicolumn{5}{|c|}{ 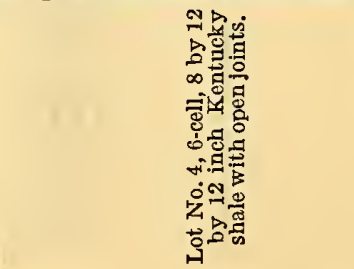 } & \\
\hline
\end{tabular}




\begin{tabular}{|c|c|c|c|c|c|c|c|c|c|c|}
\hline సีః & \&ี $\|$ & 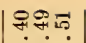 & | क्ष" & $\infty \%$ & 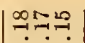 & $\cong$ & 궁유 & 위। & \&.ం & $\infty$ \\
\hline สิ สิำ & $\overrightarrow{\mathrm{N}}$ & $\mid$ & \begin{tabular}{|l||}
$\forall$ \\
$\forall$
\end{tabular} & 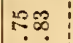 & สะฺ & $\overline{8}$ & 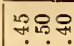 & \begin{tabular}{|l|}
29 \\
\end{tabular} & 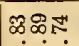 & $\underset{\infty}{\infty}$ \\
\hline 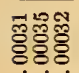 & of & 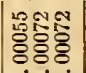 & 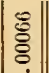 & $\begin{array}{l}\text { 항형 } \\
\overline{8}\end{array}$ & 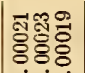 & ఫิธ్ & 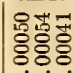 & \begin{tabular}{|l|}
$\infty$ \\
\multirow{2}{*}{} \\
\end{tabular} & $\begin{array}{l}\text { \%ळ\% } \\
\text { 잉유. }\end{array}$ & ळू \\
\hline 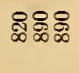 & \begin{tabular}{|l||} 
\\
$\infty$ \\
$\infty$
\end{tabular} & 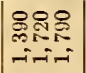 & 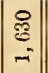 & $\begin{array}{l}\text { 90ㅇㅇㅇ } \\
\text { sim }\end{array}$ & 영윰요 & : & 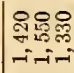 & 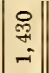 & \begin{tabular}{|l} 
웅요 \\
or \\
incio
\end{tabular} & $\begin{array}{l}\text { 음 } \\
\text { oi }\end{array}$ \\
\hline S50 & $\mid$\begin{tabular}{l||}
8 \\
量 \\
$\sim-1$
\end{tabular} & 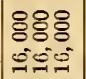 & $\left|\begin{array}{|c||}8 \\
0 \\
\vdots \\
=\end{array}\right|$ & 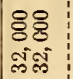 & 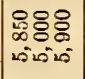 & 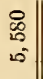 & 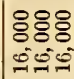 & 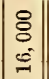 & 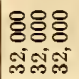 & $\begin{array}{l}\text { ¿े } \\
\text { অ. }\end{array}$ \\
\hline 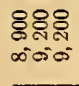 & $\frac{8}{\circ}$ & 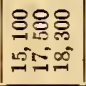 & 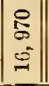 & 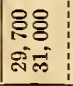 & 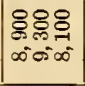 & $\left|\begin{array}{|}\mathbb{2} \\
\infty \\
\infty \infty^{\circ}\end{array}\right|$ & 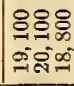 & 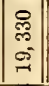 & 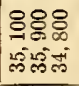 & 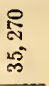 \\
\hline 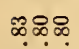 & $\stackrel{0}{\infty}$ & ఱळః & 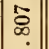 & $\infty \propto$ & 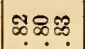 & $\mid \vec{\infty}$ & జర్య & 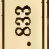 & 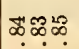 & 品 \\
\hline 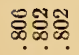 & 吕. & 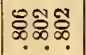 & 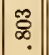 & ६ః. & 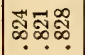 & $\mid$\begin{tabular}{|l}
$\vec{\infty}$ \\
.
\end{tabular} & స్లై & $\mid$\begin{tabular}{|l|}
$\vec{\infty}$ \\
$\infty$
\end{tabular} & 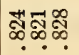 & స్. \\
\hline : & : & p: & 돈. & ำ & تே. & 员 & 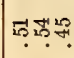 & . & 운윤 & \& \\
\hline 旅急 & 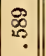 & 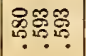 & 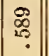 & 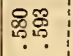 & 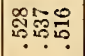 & 帘 & 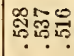 & 䆛 & 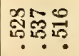 & ติ \\
\hline . & $\mid$ & 폅. & $\left|\begin{array}{|l|}18 \\
0 \\
0\end{array}\right|$ & 푱: & 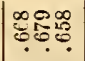 & $\left|\begin{array}{l|}\infty \\
\stackrel{0}{0} \\
\stackrel{c}{0}\end{array}\right|$ & 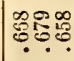 & $\left|\begin{array}{|c|}\mid \\
\vdots \\
\vdots \\
.\end{array}\right|$ & m. & $\stackrel{0}{\circ}$ \\
\hline & 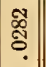 & 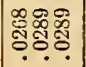 & 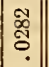 & 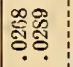 & 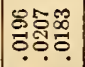 & $\mid \begin{array}{l}0 \\
0 \\
0 \\
0\end{array}$ & $\mid \begin{array}{l}\infty \\
0 \\
0 \\
0\end{array}$ & $\left|\begin{array}{|c|}\mid \\
\vdots \\
\vdots \\
\vdots\end{array}\right|$ & 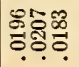 & 营 \\
\hline 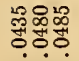 & . & 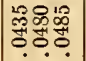 & 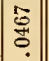 & 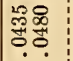 & 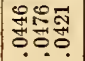 & 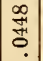 & 웡형 & $\mid$ & 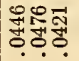 & 舫 \\
\hline 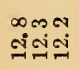 & 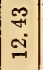 & 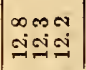 & 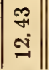 & 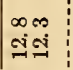 & 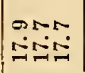 & $\mid$\begin{tabular}{l}
5 \\
5 \\
\hdashline
\end{tabular} & $\begin{array}{l}\operatorname{arn} \\
-\pi=0\end{array}$ & 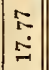 & 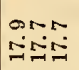 & $\stackrel{5}{\stackrel{5}{\leftrightarrows}}$ \\
\hline P. & 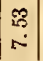 & 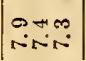 & 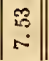 & 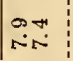 & $\begin{array}{l}\operatorname{arn} \\
\sin \end{array}$ & \begin{tabular}{l}
\multirow{2}{*}{} \\
$\therefore$
\end{tabular} & ont & $\begin{array}{l}\hat{N} \\
\therefore\end{array}$ & or & $\stackrel{5}{i}$ \\
\hline 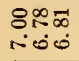 & $\begin{array}{l}\infty \\
\infty \\
0\end{array}$ & 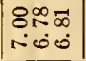 & \begin{tabular}{l||}
$\infty$ \\
$\infty$ \\
$\vdots$
\end{tabular} & 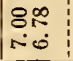 & 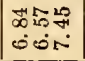 & \begin{tabular}{|c|}
2 \\
0 \\
0 \\
0
\end{tabular} & $\begin{array}{ll}\overrightarrow{1} & 5 \\
0 & 10 \\
0 & 0\end{array}$ & \begin{tabular}{|c||}
2 \\
8 \\
0 \\
0
\end{tabular} & 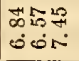 & $\begin{array}{l}\mathscr{8} \\
0 \\
0\end{array}$ \\
\hline$\pi-1$ & -1 & $\mid$ NNल & $|\sim| \mid$ & mos & $\mid \rightarrow-1$ & $\mid-1$ & | NNल & $|\infty|$ & m) & $\infty$ \\
\hline 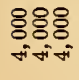 & $\begin{array}{l}8 \\
\vdots \\
\sigma^{\circ}\end{array}$ & 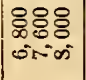 & 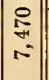 & 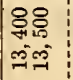 & 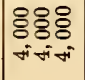 & $\begin{array}{l}8 \\
\Xi \\
-j\end{array}$ & 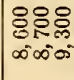 & $\mid$ & 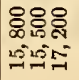 & $\begin{array}{l}\text { 은 } \\
\text { s }\end{array}$ \\
\hline se & 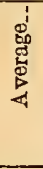 & 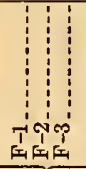 & 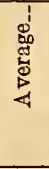 & 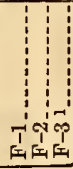 & $\begin{array}{r} \\
5 \\
5 \% 0 \\
\text { T.00 }\end{array}$ & 焉 & $\begin{array}{r}1 \\
1 \\
50 \\
000 \\
\end{array}$ & 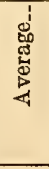 & $\begin{array}{r} \\
5 \\
500 \\
000\end{array}$ & 递 \\
\hline & & 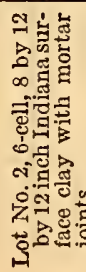 & & & & & 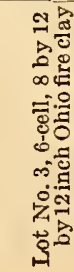 & & & \\
\hline
\end{tabular}




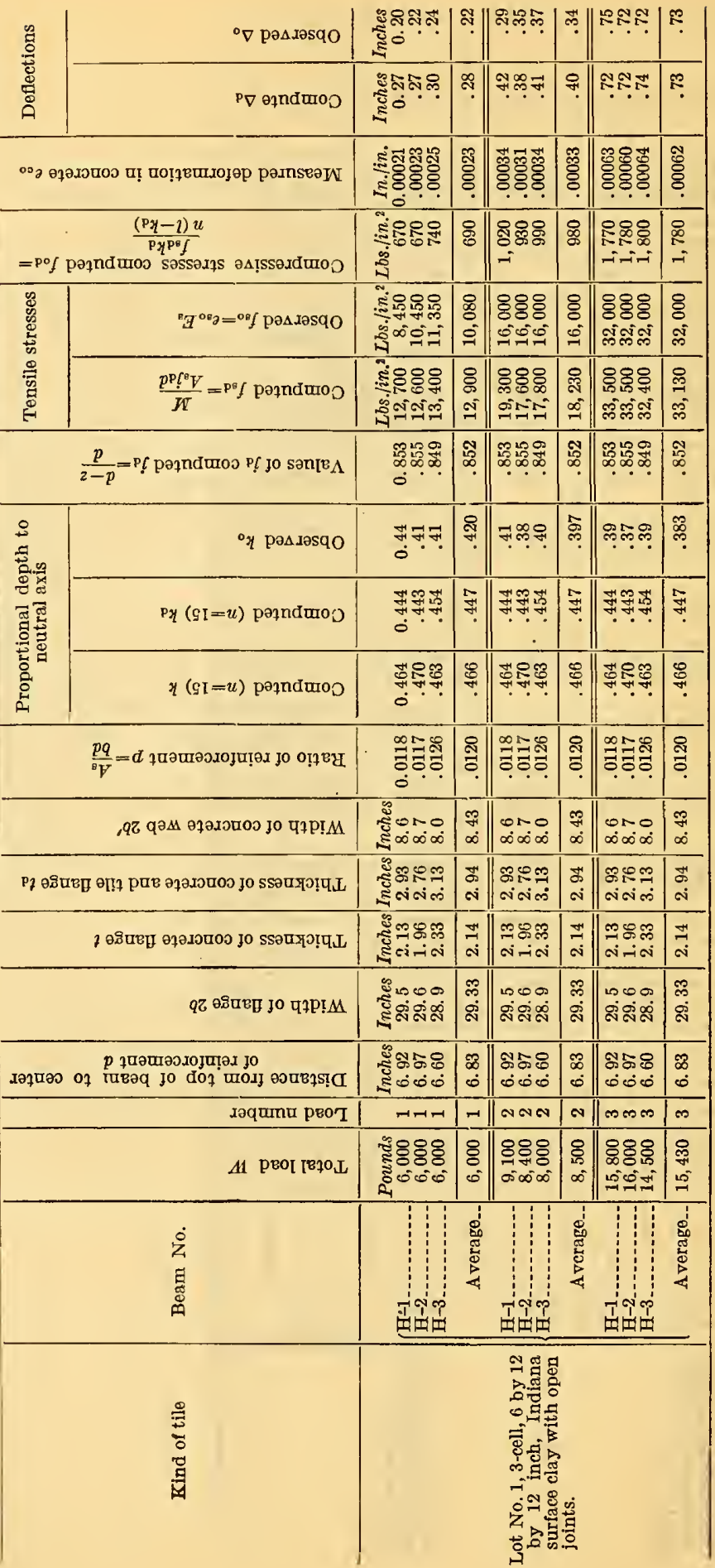


symbols used in the 1924 report of the Joint Committee for Concrete. The others have modified meanings as explained.

It should be noted that all symbols and formulas refer to one unit of width of a completed floor slab. In the combination beams this unit was a 16-inch concrete and tile rib, consisting of 4 inches of concrete bordered by two half tiles. In the concrete beams this unit was one-half the width of the beams. Thus, each beam tested represented two units of width of a floor slab. The weights of the beams were disregarded in all calculations.

$* A_{\mathbf{5}}=$ effective cross-sectional area of steel reinforcement in tension.

$* b=$ width of rectangular section of concrete or width of concrete flange in $\mathrm{T}$ beam.

Note.-The beams with topping ( $H-1, H-2, H-3$, fig. 1$)$ are considered as $\mathrm{T}$ beams.

$b_{\mathrm{d}}=$ width of concrete plus an empirical correction proportional to the thickness of the vertical tile shells and webs to take account of the increased stiffness of the beams due to the tiles.

$$
b_{\mathrm{d}}=b+2(s+w) \frac{E_{\mathrm{t}}}{E_{\mathrm{o}}}
$$

$b_{\mathrm{m}}=$ width of concrete plus a similar empirical correction to take account of the increased strength of the beam in bending due to the tiles.

$$
b_{\mathrm{m}}=b+1.3(s+w) \frac{E_{\mathrm{t}}}{E_{\mathrm{c}}}
$$

$b_{\text {teo }}=$ the equivalent increase in $b$ due to the tiles, computed from the observed strain $e_{c o}$ in the concrete. (See fig. 12.)

$b_{\text {tko }}=$ the equivalent increase in $b$ due to the tiles, computed from the observed ratio $k_{0}$ of depth of neutral axis to depth $d$. (See fig. 13.)

$b_{t} \Delta_{o}=$ the equivalent increase in $b$ due to the tiles, computed from the observed deflection of the beam $\Delta_{0}$. (See fig. 14.)

$b^{\prime}=$ width of rectangular section of concrete or width of stem in $T$ beam.

Note.-This modification of the standard notation makes the shear formula for rectangular and $\mathrm{T}$ beams identical in form.

$b^{\prime}{ }_{m}=$ width of concrete web plus an empirical correction proportional to the thickness of the vertical tile shells and webs.

$$
b^{\prime}{ }_{m}=b^{\prime}+2(s+w)
$$

$* d=$ depth from compression surface of beam to center of longitudinal tension reinforcement.

$e_{\mathrm{oo}}=$ observed strain in the extreme fiber of concrete. 
$e_{\mathrm{so}}=$ observed strain in the steel measured on the bottom of the bars.

$e_{\text {to }}=$ observed strain in the extreme fiber of the tiles.

$* E_{\mathrm{c}}=$ modulus of elasticity of concrete in compression.

$E_{\mathrm{s}}=$ modulus of elasticity of steel in tension $=29,000,000 \mathrm{lbs} . / \mathrm{in} .{ }^{2}$, instead of $30,000,000$ as adopted in joint committee report. (See Table 1.)

$E_{\mathrm{t}}=$ modulus of elasticity of tile in compression.

$* f_{\mathrm{c}}=$ compressive stress in extreme fiber of concrete. Here computed by the formula

$$
f_{\mathrm{c}}=\frac{f_{\mathrm{s}}}{n}\left(\frac{k}{1-k}\right)
$$

conveniently expressed for rectangular beams as

$$
f_{\mathrm{c}}=\frac{2 M}{k j b d^{2}}
$$

$f_{\mathrm{cd}}=$ compressive stress in extreme fiber of concrete in composite beams computed by the above formula by replacing $k, j$, and $b$, by $k_{\mathrm{d}}, j_{\mathrm{d}}$, and $b_{\mathrm{d}}$.

$f_{\mathrm{cm}}=$ compressive stress in extreme fiber of concrete in composite beams computed by the above formula by replacing $k, j$, and $b$ by $k_{\mathrm{m}}, j_{\mathrm{m}}$ and $b_{\mathrm{m}}$.

${ }^{*} f_{\mathrm{s}}=$ tensile stress in longitudinal reinforcement. Here computed by the formula $f_{\mathrm{s}}=\frac{M}{A_{\mathrm{s}} j d}$.

$f_{\mathrm{sd}}=$ tensile stress in longitudinal reinforcement of composite beams computed by the above formula by replacing $j$ by $j_{\mathrm{d}}$.

$f_{\mathrm{sm}}=$ tensile stress in longitudinal reinforcement of composite beams computed by the above formula by replacing $j$ by $j_{\mathrm{m}}$.

$f_{\mathrm{so}}=$ tensile stress in longitudinal reinforcement computed from the measured deformation. $f_{\mathrm{so}}=E_{\mathrm{s}} e_{\mathrm{so}}$.

$* j=$ ratio of lever arm of resisting couple to depth $d$, conveniently expressed for rectangular beams as $j=1-\frac{k}{3}$.

$j_{\mathrm{d}}=$ ratio of lever arm of resisting couple to depth $d$ in composite beams, computed by the above formula by replacing $k$ by $k_{\mathrm{d}}$.

$j_{\mathrm{m}}=$ ratio of lever arm of resisting couple to depth $d$ in composite beams, computed by the above formula by replacing $k$ by $k_{\mathrm{m}}$. 
$j_{0}=$ ratio of lever arm of resisting couple to depth $d$ in composite beams, computed from observed deformations by the above formula by replacing $k$ by $k_{0}$.

$* k=$ ratio of depth of neutral axis to depth $d$. Here computed by the formula-

For rectangular beams

For $\mathrm{T}$ beams

$$
k=\sqrt{2 p n+(p n)^{2}}-p n
$$

$$
k=\frac{2 n d A_{\mathrm{s}}+b t^{2}}{d\left(2 n A_{\mathrm{s}}+2 b t\right)}(\text { assumed } n=15)
$$

$k_{\mathrm{d}}=$ ratio of depth of neutral axis to depth $d$ computed by the above formulas by replacing $p$ and $t$ by $p_{\mathrm{d}}$ and $t_{\mathrm{d}}$.

$k_{\mathrm{m}}=$ ratio of depth of neutral axis to depth $d$ computed by the above formula by replacing $p$ by $p_{\mathrm{m}}$.

$k_{\mathrm{o}}=$ ratio of depth of neutral axis to depth $d$ calculated from observed deformations.

$$
k_{\mathrm{o}}=\frac{e_{\mathrm{co}}}{e_{\mathrm{co}}+e_{\mathrm{so}}}
$$

$* l=$ span length of beam (distance from center to center of supports).

* $M=$ bending moment.

$*_{n}=$ ratio of modulus of elasticity of steel to that of concrete.

$$
n=\frac{E_{\mathrm{s}}}{E_{\mathrm{o}}}
$$

${ }^{*} p=\frac{A_{\mathrm{s}}}{\bar{b} d}=$ ratio of effective area of tensile reinforcement to effective area of concrete in beams. Corresponding to this also:

$$
p_{\mathrm{d}}=\frac{A_{\mathrm{s}}}{b_{\mathrm{d}} d} \text { and } p_{\mathrm{m}}=\frac{A_{\mathrm{s}}}{b_{\mathrm{m}} d}
$$

$s=$ thickness of one vertical tile shell (outer wall). (See Table 3.)

$*_{\mathrm{t}}=$ Thickness of the concrete flange of $T$ beams.

NoтE.-The composite beams with topping ( $H-1, H-2, H-3$, fig. 1) are considered as $T$ beams.

$t_{\mathrm{d}}=$ thickness of the concrete flange plus thickness of top shell of tile in contact with concrete in composite beams with topping.

$v=$ shearing stress.

$$
v=\frac{V}{b^{\prime} j_{0} d}
$$

This differs from the notation of the joint committee in that $j_{\mathrm{o}}$ is used instead of $j$. 
$v_{\mathrm{m}}=$ shearing stress computed by the above formula for the composite beams by replacing $b^{\prime}$ by $b^{\prime}{ }_{\mathrm{m}}$.

$* V=$ total shear, pounds.

$w=$ thickness of one vertical tile web (partitions dividing the tile into cells). (See Table 3.)

$z=$ depth from compression surface of beam to resultant of compressive stresses.

$\Delta_{\mathrm{o}}=$ observed deflection at the center of beam.

$\Delta_{\mathrm{d}}=$ deflection of the center of the beam, computed by the formula. ${ }^{12}$

$$
\Delta_{\mathrm{d}}=q \frac{7^{2}}{d}\left(e_{\mathrm{s}}+e_{\mathrm{c}}\right)
$$

where $q$ is a constant depending on manner of loading. $q=0.105$ for these tests, and

$e_{\mathrm{s}}=\frac{f_{\mathrm{sd}}}{E_{\mathrm{s}}}$ with $E_{\mathrm{s}}$ taken as $29,000,000$ lbs./in. ${ }^{2}$

$e_{\mathrm{c}}=\frac{f_{\mathrm{cd}}}{E_{\mathrm{c}}}$ with $E_{\mathrm{o}}$ taken as $3,625,000 \mathrm{lbs}$. /in. ${ }^{2}$ corresponding to $n=8$.

By comparing the curves in Figures 8, 9, 10, and 11 and the experimental data in Table 4 for the concrete beams with those for the combination beams it is apparent that the tiles were effective in reducing the compressive deformations in the concrete, the deflections, and the values of $k_{0}$. The hard tiles had a greater effect than the soft tiles. The average of the computed values of $k_{\mathrm{a}}$ given in Table 4 are, for the concrete beams, slightly smaller than the average determined by tests. This is in accord with the results of other tests ${ }^{13}$ and is to be expected on account of the inexactness of the assumptions upon which the formula employed is based. The tensile resistance of the concrete which is neglected in the formula probably had an important effect at low loads, and the deviation of the stressstrain relation for the concrete from the assumed linear relation probably had an important effect at the higher loads. However, for the combination beams the averages of the computed values for $k_{\mathrm{d}}$ are greater than the test values $k_{0}$; that is, the effect of the tiles was, in all cases, to cause the neutral axis to lie above the position it would have taken if the concrete were alone resisting the compressive stresses.

Although there are a number of methods which may be used in comparing the concrete beams with the combination beams without

12 G. A. Maney, "Relation between deformation and deflection in reinforced concrete beams" Proc. A. S. T M., 14, Pt. 1I, p.311; 1914

${ }_{13}$ Humphrey and Losse, The Strength of Reinforced Concrete Beams-Results of Tests of 333 Beams (first series). B. S. Tech. Paper No. 2. 
topping to estimate the effect of the tiles upon the deformations of the beams, it is of obvious advantage to employ as simple a method as can be found. Probably the least difficult method to employ in design is to consider that each concrete and tile rib is, as far as deformations are concerned, equivalent to a homogeneous, rectangular concrete section to which the ordinary principles of analysis may be applied. If, in the combination beams without topping, the size, shape, and design of the tiles are the same, and the distribution of the compressive deformations is similar in tiles possessing different properties, the effect of the tiles in increasing the breadth of the equivalent rectangular concrete section should be proportional to the ratio $\frac{E_{\mathrm{t}}}{E_{\mathrm{c}}}$; that is, the amount by which the breadth of a concrete rib should be increased to form the equivalent concrete section, having for the same deformations the same resisting moment as the combination beam, would be equal to the ratio $\frac{E_{\mathrm{t}}}{E_{\mathrm{o}}}$ multiplied by a factor whose value could be determined experimentally. The value of this factor would be constant only for tiles of exactly the same dimensions. Since the outside dimensions and total weights of tiles of any given design must be very nearly equal in order to fulfill the requirements of a specification, it follows that the thickness of the shells and webs of tiles, equal in weight, must vary inversely with the bulk density of the material of which the tile is composed. The value of the experimental factor, therefore, will vary in some manner, with variations in the thickness of the tile shells and webs. The dimensions of the tiles in the combination beams without topping were approximately the same except for the thicknesses of the vertical shells and webs. The discussion so far has referred only to the relation between the deformations of the beams and bending moments less than the maximum. A similar method would seem to be the simplest way of comparing the strengths of the combination beams without topping with those of the concrete beams. The empirical factor, however, should not be expected to be the same in both cases. As will be shown later, the results indicate that at loads less than the maximum each concrete and tile rib was approximately equivalent, in resisting deformations, to a rectangular concrete beam having a width at least equal to $2(s+w) \frac{E_{\mathrm{t}}}{E_{\mathrm{c}}}+b$. Similarly, on the basis of the maximum bending moments actually resisted by the combination beams, each concrete and tile rib was approximately equivalent in strength to a rectangular concrete beam having a width at least equal to $1.3(s+w) \frac{E_{\mathrm{t}}}{E_{\mathrm{c}}}+b$, the empirical factor in this case 
being smaller than in the case of the deformations. Both coefficients given are empirical, and although no direct expression appears for the effect of the top shells of the tiles it is obvious that the effect of their resistance is included. It is also obvious that for tiles with a different distribution of thickness between vertical and horizontal shells and webs different values for these empirical coefficients should be expected.

Since the beams with a 2 -inch concrete topping were similar to concrete $T$ beams, it is more convenient to consider them as such in making comparisons than to use the method employed in comparing the combination beams without topping. On account of the position of the tiles relative to the neutral axis the assistance of the tiles in resisting compressive stresses in the beams with topping was not as great as in those without the topping. The greater area of the tiles in contact with the concrete should, however, have caused a more uniform distribution of the stress throughout the tiles. Since only one grade of tiles was used in the beams with topping, no conclusions could be drawn as to the effect of differing physical properties of the tiles upon beams of this type, although it seems certain that such an effect must exist. The simplest method to employ seemed to be to consider that the effect of the tiles was approximately equivalent to adding to the thickness of the concrete flange an amount proportional to the thickness of the top shell of the tile in contact with it, multiplied by an empirically determined factor. As will be shown in the discussion later, the effect upon deformation and strength in these beams was practically the same, so that the same factor could be used in both cases. The results indicated that for all practical purposes this factor could be taken as one. This would probably be modified if the modulus of elasticity of the tiles differed greatly from the modulus of elasticity of the concrete.

\section{(b) CONCRETE BEAMS}

The results of tests of the concrete beams are in accord with those found in previous investigations in that (1) the observed values of $k_{\text {o }}$ were greater than the computed values $k ;^{14}(2)$ the strain in the extreme fiber at maximum loads was greater than the maximum strain in the corresponding test cylinders; ${ }^{14,15}$ (3) the compressive stresses in the beams for the maximum loads when computed by the straight line formula greatly exceeded the stresses which caused the failure of the test cylinders and prisms. ${ }^{16}$. In beams of ordinary size and design the computed stresses in the reinforcement are

14 Humphrey and Losse, The Strength of Reinforced Concrete Beams-Results of 'Tests of 333 Beams (first series). B. S. Tech. Paper No. 2.

${ }^{15}$ Bul. No. 175, Univ. of Wis., 1907.

${ }^{16}$ Slater and Zipprodt, "Compressive strength of concrete in flexure," Proc. Amer. Concrete Inst., 16, 1920. 
greater than the stresses determined from observed deformations. ${ }^{17}$ It will be noted in Table 4 that for loads numbers 2 and 3 the observed tensile stresses in beams B are greater than the computed stresses. The chief causes for this discrepancy are (1) use of the straight line formula with very high stresses in the concrete; (2) the nominal area of the bars was 3 per cent greater than the measured area, and as the computed stresses were based upon the nominal area they should be increased by about 3 per cent; and (3) the deformations measured on the bottom of the bars were considered to be the average deformation of the steel, whereas the depth $d$ used in the computations was the distance from the compression surface to the center of the bars. In the beams of ordinary depths the deformations on the bottom of the reinforcement are nearly equal to the average deformations of the bar, but in beams $B$ the distance from the gauge lines to the centroid of the steel area was more than 20 per cent of the average distance from the neutral axis to the centroid of the steel area, so that the stresses in the bottom of the reinforcement were greater than at the center, the difference probably approaching 20 per cent at loads below the yield point in the steel. If the measured deformations had been corrected linearly to the center of the reinforcement bars the computed stresses would have exceeded the observed values slightly, and the results would then be in accord with the results of previous tests.

\section{(c) COMBINATION BEAMS WITH NO TOPPING}

1. Concrete Deformations, Depth to the Neutral Axis, Deflections, And Steel Stresses.- Since the width of the concrete and the depth to the steel were not the same in all beams, some method of reducing the test values of $k_{0} e_{\mathrm{co}}$, and $\triangle_{\mathrm{o}}$ to a common basis must be employed in order to compare the properties of the combination beams with the properties of the concrete beams and to determine the effect of the properties of the tiles upon their action in the beams. Each combination beam may be considered to be equivalent to a concrete beam of the same depth and containing the same amount of reinforcement and having a width such that its computed deformation in the concrete, position of neutral axis, and deflection would be equal to the observed values. It is not to be expected that concrete beams equal in width to the values given by such computations will actually be equivalent to the corresponding beams, for, on account of the variations between the conditions in the beams and the assumed conditions upon which the formulas are based, it is impossible for the computed values to equal the test values for all

17 Westergard and Slater, "Moments and stresses in slabs," Proc. Amer. Concrete Inst., $17,1921$. 
loads. However, by comparing the concrete beams with the combination beams, some relation between the properties of the tile and their effect upon the action of the beams under load, at loads less than the maximum, may be seen.

The effect of the tiles upon the compressive deformations in the concrete.-In comparing the beams to determine the effect of the tiles upon the deformation in the concrete the width of rectangular beams, for which the computed deformation in the concrete would equal the measured deformation, were determined for three series of loads, as shown in Figure 12. The difference, $b_{\text {teo, }}$ between the widths of these equivalent concrete beams thus determined and the net width $b$ of the concrete ribs was considered to be a measure of the effect of the tiles upon the deformations in the concrete. The values plotted in Figure 12 indicate that the effect of the tiles upon the compressive deformations in the concrete was approximately equivalent to adding widths of concrete to the ribs proportional to values of $(s+w) \frac{E_{\mathrm{t}}}{E_{\mathrm{c}}}$. This relation is seen to hold for a wide range of loads.

The effect of the tiles upon the position of the neutral axis.-From the average of the observed values of $k_{0}$ given in Table 4 for similar beams the values of $p$ corresponding to $k_{0}$ with the assumed value $n=15$ were first computed. From the known area of reinforcement and known depth the width of beams corresponding to these values of $p$ were then computed. The difference, $b_{\text {tko }}$, between the width of the equivalent concrete beams, for which the computed depth to the neutral axis was equal to the observed depth and the net width $b$ of the concrete ribs, was taken as a measure of the effect of the tiles upon the depth of the neutral axis. The relation between the values plotted in Figure 13 indicates that the effect of the tiles upon the position of the neutral axis was approximately equivalent to adding witths of concrete to the ribs proportional values of $(s+w) \frac{E_{\mathrm{t}}}{E_{\mathrm{c}}}$ the same quantity as above.

The effect of the tiles upon the beam deflections.-In order to compare the different beams to determine the effect of the tiles upon the deflections, it was assumed that the effect of the differences in dimensions were approximately given by Maney's formula modified as shown in the title of Figure 14 . The relation between the values plotted in Figure 14 indicates that the effect of the tiles upon the beam deflections was approximately equivalent to adding widths of concrete to the ribs again proportional to the values of $(s+w) \frac{E_{t}}{E_{\mathrm{c}}}$.

It is obvious that values such as those given in Figures 12, 13, and 14, which are functions of deformations and which indicate the effect of the tiles upon the deformations of the beams at loads less than the maximum, do not indicate the maximum strength of the con- 
struction or the value of the tiles in increasing the strength of the beams. Beams of such a composite character may fail in some other manner before the ultimate compressive strength of the construction has been developed. The failure may be caused by the failure of an individual tile or by the failure of the bond between the tiles and concrete or by the concentration of stress in a part of the concrete caused by the lack of continuity of the tiles. Furthermore, the average

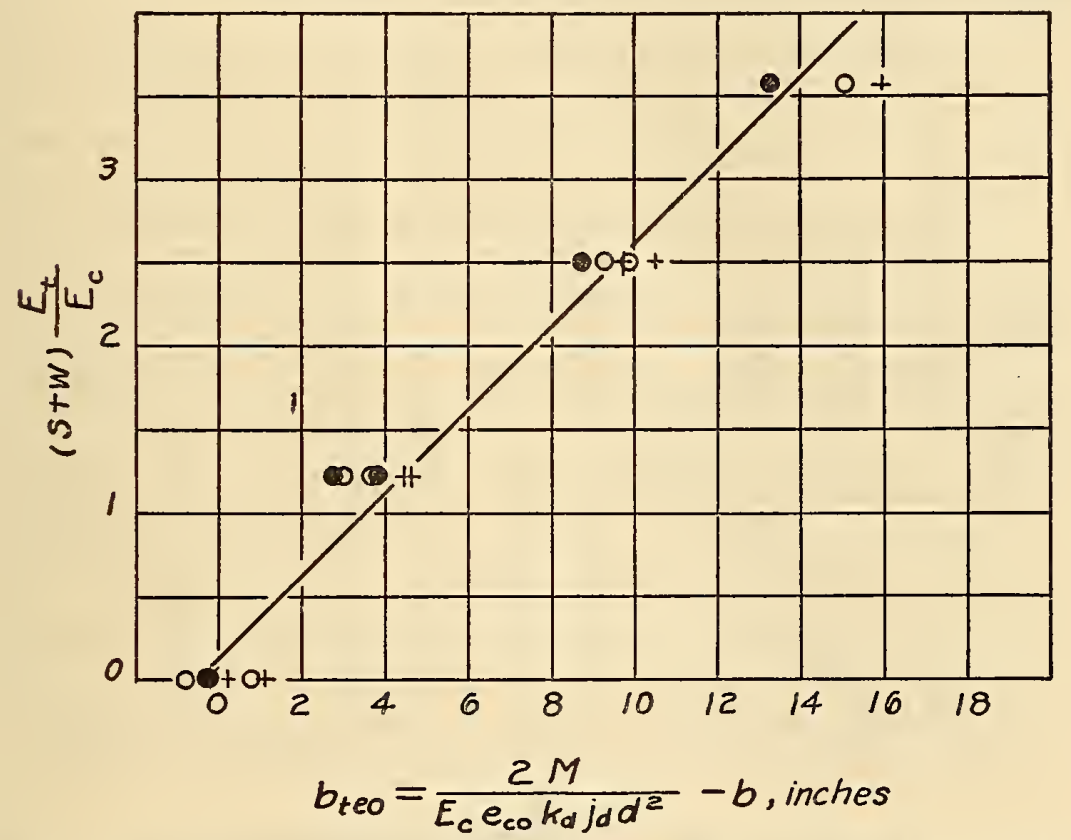

FIG. 12.-Showing that the effect of the tiles upon the compressive deformations in the concrete was approximately proportional to the product of the modulus of elasticity of the tiles by the thickness of the vertical shells and webs

The formula

$$
f_{\mathrm{c}}=E_{\mathrm{c}} e_{\mathrm{eo}}=\frac{2 M}{k_{\mathrm{d}} j_{\mathrm{d}}\left(b_{\mathrm{teo}}+b\right) d^{3}}
$$

was solved for $b_{\text {teo. }} E_{\mathrm{c}}$ was taken as $2,000,000 \mathrm{lbs} . / \mathrm{in} .^{2}$ and $k_{\mathrm{d}} j_{\mathrm{d}} d^{2}$ were the averages of the values for similar beams given in Table 4. The values shown by crosses were computed from values of $M$ and $e_{c o}$ at load 1 and those shown by open circles from values of $I I$ and $e$ co at load 2, Table 4 . In order to minimize the effect at high loads of the deformation in the concrete not bearing a constant relation to the stress, the third load was interpolated from the load deformation curves to give an average compressive strain in the concrete of 0.00080 inch per inch. The values shown by full circles were computed from values of $M$ corresponding to $e_{\mathrm{co}}=0.00080$.

compressive deformation at which compression failures occur may be less than that at which the compression failure of concrete beams may be expected. These considerations, however, do not alter the relations shown in Figures 12, 13, and 14 resulting from these tests, but merely limit the application of their values to the deformation of the beams and the loads for which the relation is shown. All these comparisons of the combination beams without topping indicate that 
the increase in stiffness of the beams due to the tiles was approximately equivalent to adding to each concrete rib a width of concrete greater than $2(s+w) \frac{E_{\mathrm{t}}}{E_{\mathrm{c}}}$.

The computed tensile stresses in the reinforcement $f_{\text {sd }}$ and the observed stresses $f_{\mathrm{so}}$ are given in Table 4. For the combination beams the computed stresses in the reinforcement were, in general, greater than the observed stresses at the loads given.

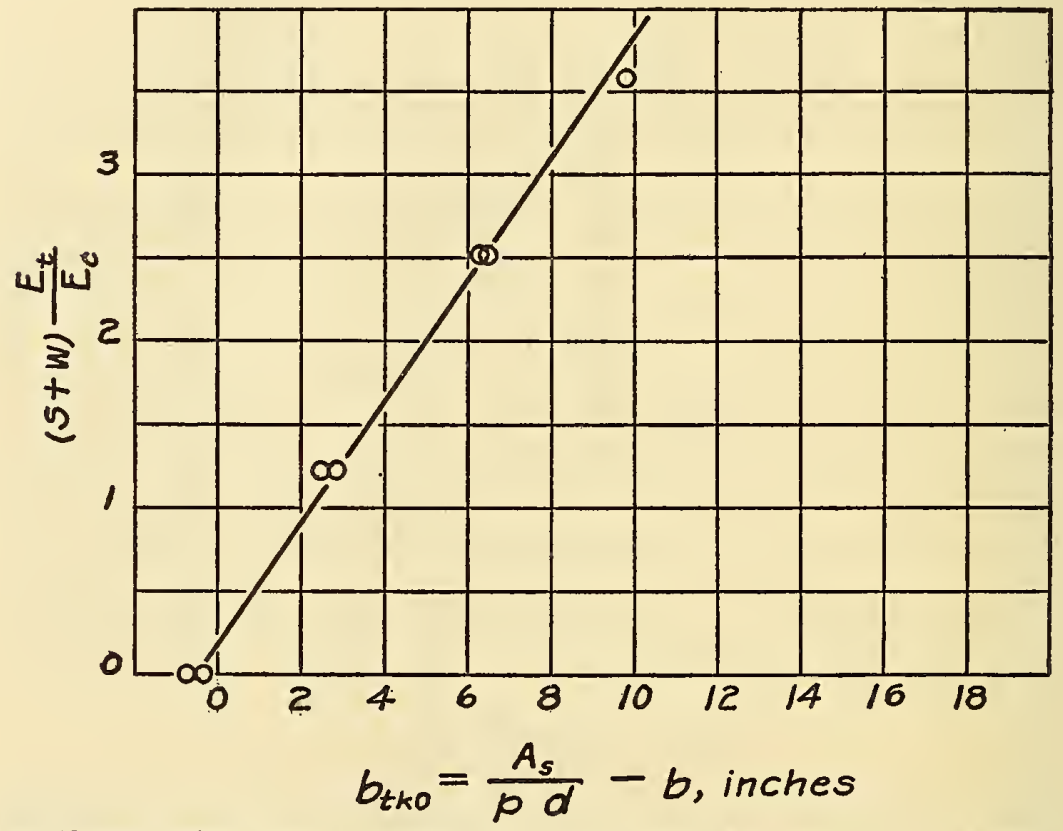

FIG. 13.-Showing that the effect of the tile upon the position of the neutral axis was approximately proportional to the product of modulus of elasticity of the tiles by the thickness of the vertieal shells and webs

In the formula $b_{\text {tko }}=\frac{A_{s}}{p d}-b$

$p$ was taken as value given by the formula

$$
p=\frac{k_{0}{ }^{2}}{2 n\left(1-k_{0}\right)}
$$

in which $n=15$ and $k_{0}$ was the average value given in Table 4 for values of $f_{\mathrm{s} o}=16,000$ lbs./in. ${ }^{2}$

2. Maximum Bending Moments and Computed Stresses.-The cause of the failures of the combination beams containing hard tiles was the tension failure of the reinforcement. In these beams there was no spalling of the concrete and tiles before the primary failure occurred, and it was evident that the full compressive strength of the concrete and tiles had not been reached. Beams B, which had the same cross sectional area as the sectional area of the two concrete ribs in the combination beams, and five of the six combination beams containing soft tiles failed in compression. 
Table 5 gives the maximum bending moments, causes of failures, and computed tensile and compressive stresses corresponding to the maximum bending moments. It is seen that the maximum computed tensile stresses for the beams which failed in tension are in fair agreement with the yield-point stress of $39,180 \mathrm{lbs} . / \mathrm{in} .^{2}$ found in the tests of the coupon specimens.

It was noted in Figures 12, 13, and 14 that the effects of the tiles upon the deformation in the concrete, the depth of the neutral axis, and the deflection of the beams were each equivalent to the effect of

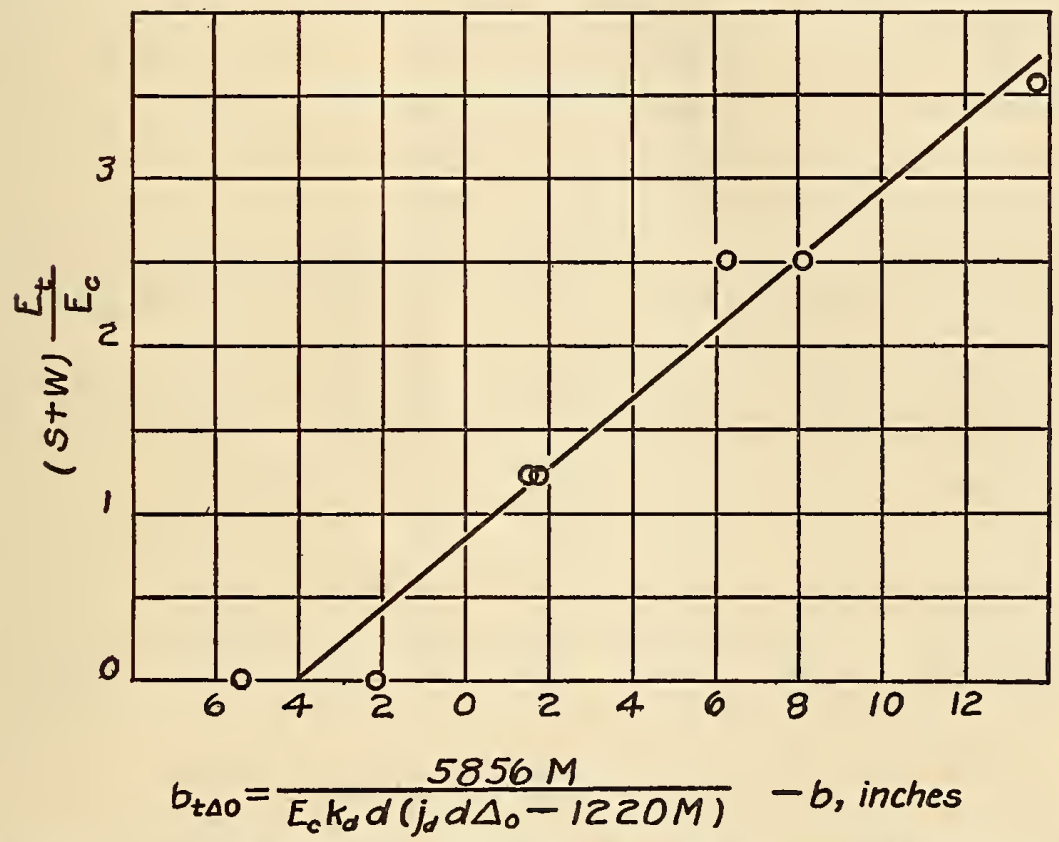

FIG. 14.-Showing that the effect of the tiles upon the deflections of the long beams was approximately proportional to the product of the modulus of elasticity of the tiles by the thickness of the vertical shells and webs

In Maney's formula $\Delta=q_{\frac{l 2}{d}}\left(e_{\mathrm{B}}+e_{\mathrm{c}}\right)$,

the measured deflection $\triangle$ o was substituted for $\triangle$,

$$
\frac{M}{E_{3} A_{\mathrm{\theta}} j_{\mathrm{d}} d^{2}} \text { for } e_{s} \text {, and } \frac{2 M}{E_{\mathrm{o}} k_{\mathrm{d}} j_{\mathrm{d}} d^{2}\left(b_{\mathrm{t}} \Delta_{\mathrm{o}}+b\right)}
$$

for $e_{c}$. The resulting equation was solved for $b_{t} \Delta_{0}$ with values of $M I$ and $\Delta_{0}$ at load number 2, Table 4. $E_{\text {s }}$ was taken as $29,000,000 \mathrm{lbs} . /$ in. $^{2}$ and $E$ c was assumed as $3,625,000$ corresponding to $n=8$. It is pointed out by Turnerure and Mauer in Principles of Reinforced Concrete, 3d ed., 1919, pp. 205, 206, the values of $n$ and $E$ c used in deflection formulas are in reality emperical coefficients, and the values employed should be those which will give computed deflections which agree approximately with test results.

adding a width of concrete proportional to $(s+w) \frac{E_{\mathrm{t}}}{E_{\mathrm{o}}}$ to the concrete ribs, and that in order to have the ordinates increase at the same rate as the abscissas it would be necessary to multiply by an empirical factor whose value would be different for each property 
TABLE 5.-Maximum bending moments, computed stresses, and causes of failures for long beams

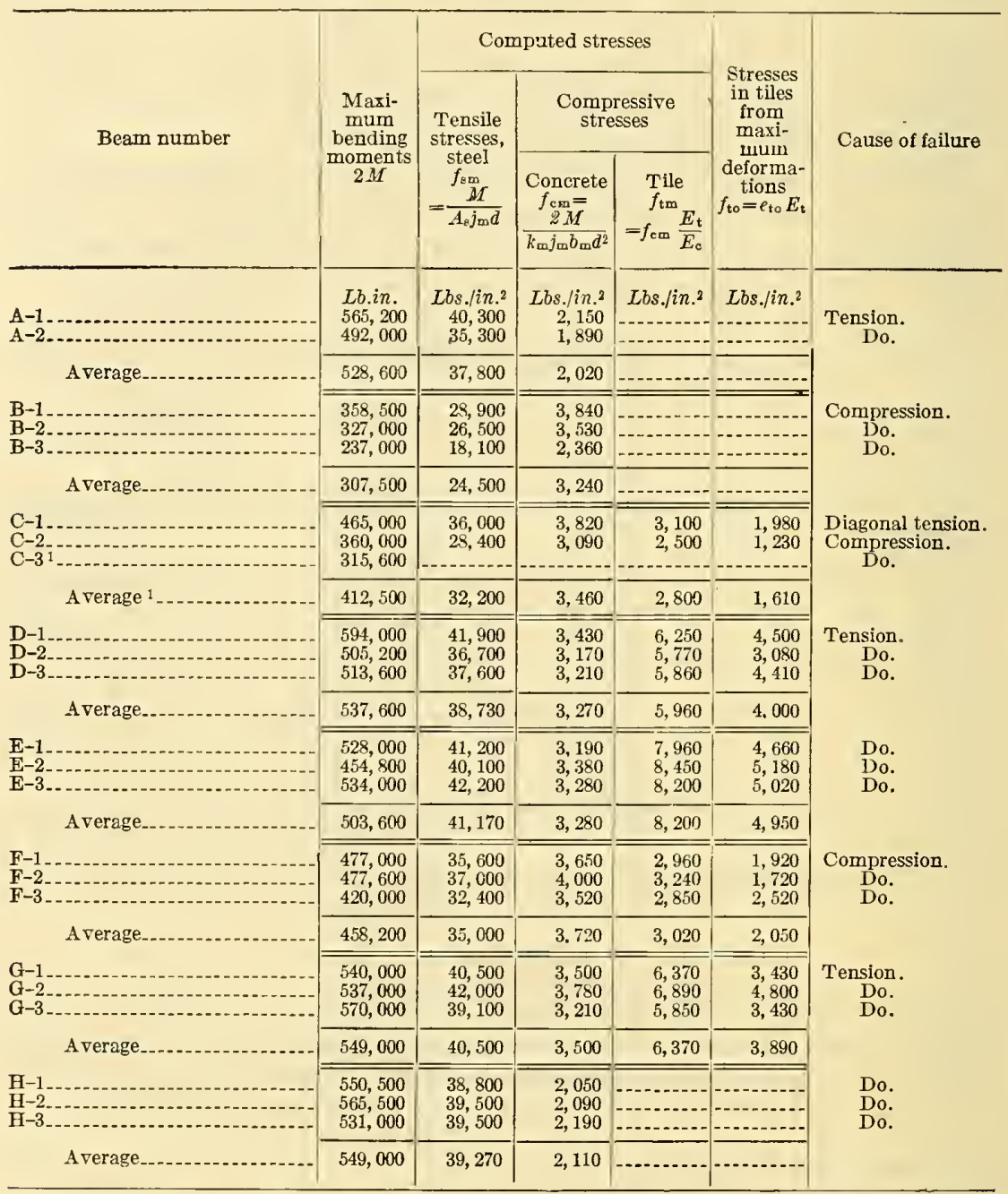

1 One tile near the center of beam C-3 was broken before the test. The average given is of beams C-1 and $\mathrm{C}-2$ only.

considered, but which, for any case, would be greater than two. The maximum loads supported by the beams and the corresponding computed compressive stresses given in Table $\tilde{j}$ indicate, however, that the effect of the tiles upon the ultimate strength of the beams was less than might be expected from their effect on the deformations of the beams at low loads. A comparison of the load-deformation curves of Figures $8,9,10$, and 11 indicates that, although the strains in the concrete of the combination beams were less than those in the concrete beams $\mathrm{B}$ at a given load, the maximum strains developed in the combination beams before compression failures were con- 
siderably less than those in the concrete beams. The average maximum compressive strain at the extreme fiber in beams $F$ was about 0.0020 inch per inch and in beams $B$ about 0.0027 inch per inch. This difference shows that the presence of the tiles did not increase the strength of the beams as much as it did their stifliness. This is probably due to the greater concentration of compressive stresses in the concrete around the joints in the composite beams. Consequently, an empirical correction in strength formulas must be less than that used in deflection or strain formulas.

The maximum compressive strength of the concrete and tiles in the combination beams containing hard tiles was not developed, but it may be conservatively measured by the maximum stress resisted. If in the general formula $f_{\mathrm{c}}=\frac{2 M}{k j b d^{2}} M$ is taken as the average of the maximum bending moments for similar beams and $f_{\mathrm{c}}$ is taken as $3,240 \mathrm{lbs}$. $/ \mathrm{in}^{2}$ (the average of the maximum computed stresses in the concrete beams which failed in compression) and the equation is solved for $b$ by a series of approximations in which $k$ and $j$ are given values corresponding to the new values of $b$, it is found that these widths will in all cases be equal to or greater than $1.3(s+w) \frac{E_{\mathrm{t}}}{E_{\mathrm{c}}}+b$. The maximum computed stresses in the concrete $f_{\mathrm{cm}}$ computed on the basis that $b_{\mathrm{m}}=1.3(s+w) \frac{E_{\mathrm{t}}}{E_{\mathrm{c}}}+b$ are given in Table 5, and it is seen that the average of the maximum computed stresses in the concrete of the combination beams was greater than the average of the maximum computed stresses in the concrete of beams B. On the assumption, therefore, that the concrete in the combination beams without topping was capable of resisting a compressive stress equal to the average maximum stress in the concrete beams which failed in compression, each concrete and tile rib of the combination beams (equivalent to one-half the beam as a whole) under the action of bending moments was equivalent in strength to similar concrete beams having a width equal to the width of one concrete rib plus the empirical correction for the tile $1.3(s+w) \frac{E_{\mathrm{t}}}{E_{\mathrm{c}}}$ with $E_{\mathrm{c}}$ taken as $2,000,000 \mathrm{lbs} . / \mathrm{in} .^{2}$

The maximum observed and computed stresses in the tiles are given in Table 5. The maximum observed stress $f_{\text {to }}$ is the product of the maximum deformation in one gauge line on each beam by the average modulus of elasticity found by the tests of the corresponding individual tiles. The computed stresses $f_{\mathrm{tm}}$ given are the products of $f_{\mathrm{cm}}$ corresponding to the maximum loads and the ratio $\frac{E_{\mathrm{t}}}{E_{\mathrm{o}}}$ in which $E_{\mathrm{c}}$ is taken as 2,000,000 lbs./in. ${ }^{2}$ The stresses com- 
puted from the observed deformations are less than maximum stresses in the tiles, for the measured deformations give the average deformations over the 8-inch gauge length, and, as the stresses in the tiles were caused by the bond between them and the concrete, the maximum intensity of the stresses was at the surface of the tiles in contact with the concrete. It would be expected on account of the shape of the stress-deformation curve for concrete in compression, that as the stresses in the concrete became high enough to cause a marked increase in the amount of deformations produced by a given increase in stresses the tiles would, on account of their straight-line stress-deformation relation, be stressed proportionately more. It is seen, however, that the observed stresses in the tiles were, even for the greatest loads, less than those computed under the assumption that $f_{\mathrm{tm}}=f_{\mathrm{cm}} \frac{E_{\mathrm{t}}}{E_{\mathrm{o}}}$.

In no case did the maximum observed stresses $f_{\text {to }}$ in the tiles equal or exceed the compressive strength of the tiles determined by the tests of 10 single tiles of each lot, but in several cases the maximum computed stresses $f_{\mathrm{tm}}$ exceeded their average compressive strength. It was not expected that such computations would yield exact values of stresses, but the tests indicate that the computed stresses in the tiles may equal or exceed the compressive strength of the tiles before a compression failure occurs.

3. Effect of Mortar Joints.-Beams C may be compared with beams $\mathrm{F}$ and beams $\mathrm{D}$ with beams $\mathrm{G}$ to determine the effect of the mortar in the cross joints. The mortar in beams $F$ and $G$ did not affect the stiffiness of the beams at low loads and seemed to have but slight effect at loads near the maximum. The computed stresses in the extreme fiber of the concrete (see Table 5) for the maximum bending moments were about 6.5 per cent greater in the beams with mortar joints than in those with open joints. The tests were not sufficient to show the effect of the mortar on the shearing strength of the beams. Although these tests were not conclusive, the effect of the mortar joints on the stiffness and strength of these beams evidently was not great.

\section{(d) COMBINATION BEAMS WITH TOPPING}

The test results given in Table 4 indicate that the deformations of beams $\mathrm{H}$ (see fig. 1) were more closely estimated by computations which considered the beams to consist of concrete $T$ beams which had flange thicknesses equal to the sum of the thickness of the concrete flange and the thickness of the top shell of the tiles, than by considering the tiles to be only inert fillers. A comparison of the values $k$ based upon the net section of the concrete with the experimental values $k_{0}$ indicates that such computations which do not 
consider the effect of the tiles result in values much too high. The values $k_{\mathrm{d}}$, computed on the assumption that the flanges consisted of the concrete and $1 \times$ the thickness of the top shells of the tiles, are more closely in agreement with the test results. The compressive stresses computed on the same assumption were, for the three loads given in Table 4, 50, 48, and 42 per cent greater than stresses computed from deformations with $E_{\text {c }}$ taken as $2,000,000$ lbs./in. ${ }^{2}$ Although $E_{\mathrm{c}}$ was probably greater than this value, it is seen that if higher values of $E_{\mathrm{c}}$ up to $2,800,000 \mathrm{lbs}$./in. ${ }^{2}$ were taken the stresses were conservatively estimated. The average observed stresses in the reinforcement were less than the average computed stresses. Except for loads near the maximum, the computed deflections were greater than those observed. These results seem to indicate that the top shells of the tiles were somewhat similar in effect to an equal thickness of concrete in their effects upon the deformations of the beams.

The maximum loads supported by beams $\mathrm{H}$ were probably considerably less than the loads which would have been required to develop the maximum compressive strength of the concrete and tiles. The yield point in the reinforcement in each of these beams was reached before there were any visible signs of compression failures. The load-deformation curves of Figure 11 show that the average of the maximum deformations developed in the concrete was about 0.0007 inch per inch, which is less than one-third the strain which usually accompanies the compression failures of concrete beams. In the beams which failed by compression the average strain at the extreme fiber in the concrete beams $B$ at failure was 0.0027 inch per inch and in the composite beams F 0.0020 inch per inch. Although the increases in the loads are not to be expected to be in proportion to the increases in deformations beyond this point, it is probable that a considerable increase in loads would have been necessary before compression failures would have been produced if the yield point in the steel had been sufficiently high. It was noted that the maximum compressive strains in the composite beams without topping were less than those in the concrete beams. The discontinuity of structure in the extreme fiber producing concentrated stresses in the concrete, which was present in the composite beams without topping, was not present in those with topping. Consequently, it would not be expected that the tiles in the beams without topping would have an important effect upon the maximum compressive strains.

The area of the tiles in contact with the concrete was much greater in the beams with topping than in those without. The deformation in the tiles should, therefore, be more nearly equal to that which would occur in concrete at the same relative position with respect to the neutral axis than in beams without a topping. 
On account of the distance of the tiles from the extreme fiber they would bear relatively less stress than in the beams without topping. Since failure of the tiles is not to be expected, the increase of stiffness due to the tiles should give a corresponding increase in strength. Therefore, concrete beams equivalent in stiffness to the combination beams with topping should also be expected to be equivalent in strength. This was not found to be true for the combination beams without topping.

(e) DISTRIBUTION OF COMPRESSIVE DEFORMATIONS ACROSS THE BEAMS

Figures 15 and 16 show the deformations for each gauge line in the concrete and tiles for the two loads which produced stresses of approximately 16,000 and $32,000 \mathrm{lbs}$./in. ${ }^{2}$ in the reinforcement. In general, the deformation in a concrete rib was greater than in the adjacent tile, and the deformation in the tiles was greatest near the concrete. The deformations measured in the outer tiles of the beams can not be considered to represent those which would be expected to occur in a complete slab, so in considering the relation of the deformation in the tiles to that in the concrete the values obtained for the center row of tiles were used. There was a wide variation in the ratio of the deformation in the tiles to that in the concrete. The average ratios for the center row of tiles are as follows: Beams $\mathrm{E}$, side shells 0.96 , center webs 0.86 ; beams $\mathrm{D}$ and $\mathrm{G}$, side shells 0.91 , center webs 0.77 ; beams $\mathrm{C}$ and $\mathrm{F}$, side shells 0.80 , center webs 0.66 .

It is not believed that the ratios of deformations are useful for determining the quantitative effect of the tiles in resisting stresses, for the deformations measured in the tiles do not necessarily represent either the maximum or the average deformations. The gauge lines were in the center of the shells and webs and covered but 8 inches of the center of the tile, and as the deformation of the tiles was produced chiefly through the bond between them and the concrete the maximum deformation in a tile should occur at the surface in contact with the concrete. Furthermore, the distribution of stress along the 8-inch gauge line was probably not uniform, and it is certain that a small length near the ends of the tiles was stressed but little if at all. The uncertainty of the distribution of the stress throughout the tiles and concrete either as to direction or intensity makes it impracticable to attempt to use the values of deformation obtained to compute the value of the tiles in assisting the concrete.

\section{SHEAR TESTS}

\section{(a) BEAMS WITHOUT WEB REINFORCEMENT}

Table 6 gives the maximum loads, maximum computed shearing stresses, spans of the supports, distance between the loads, and the causes of failures. The formulas employed in making the compu- 


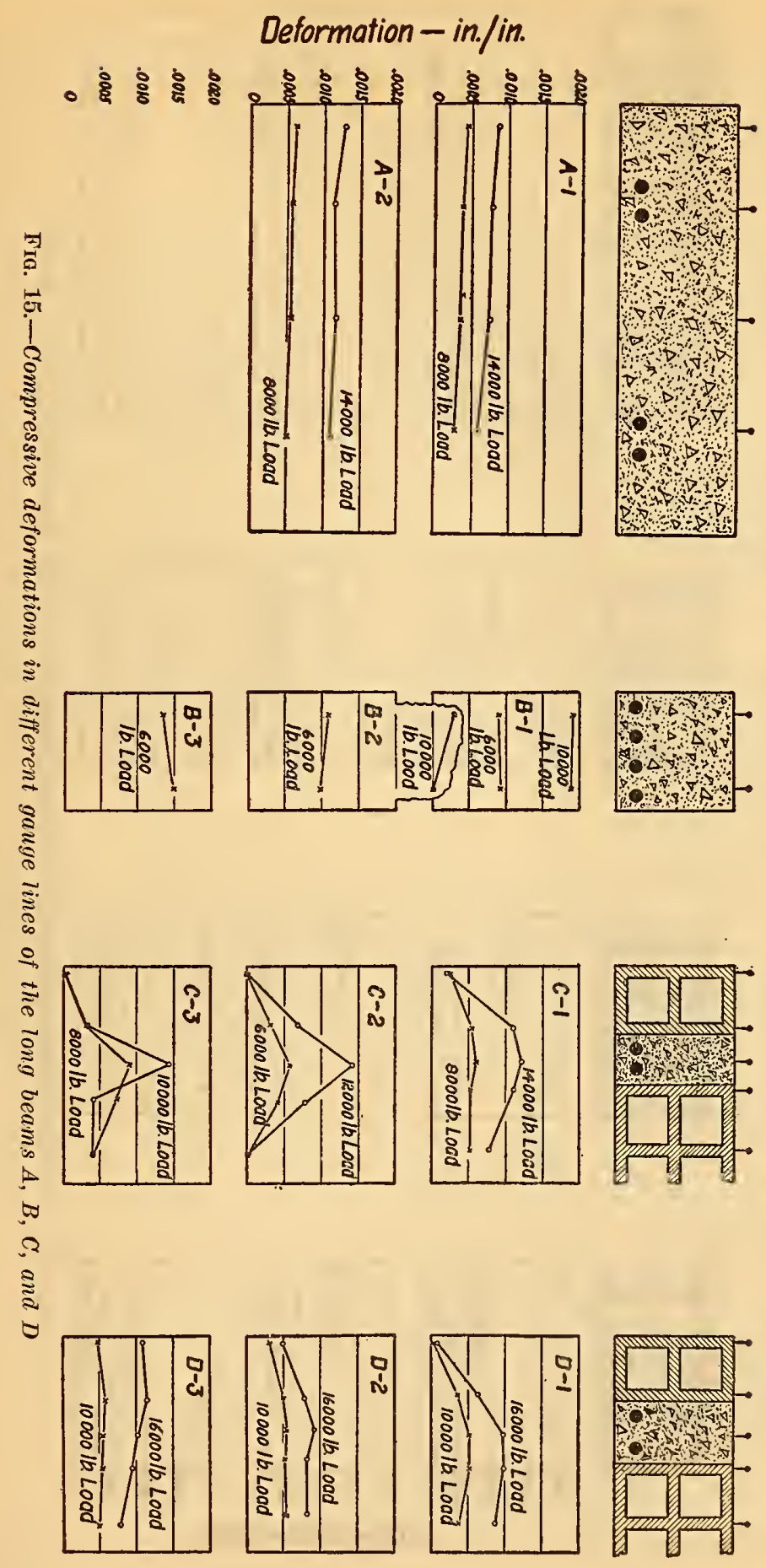



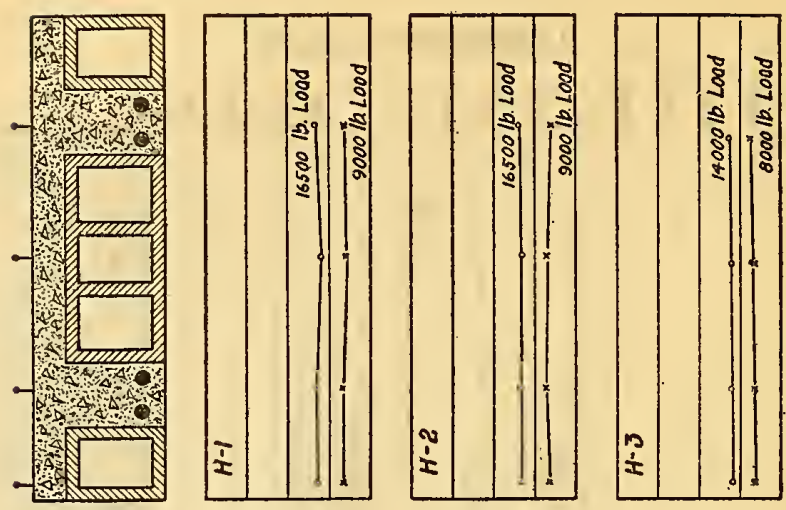

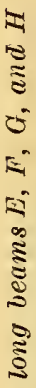
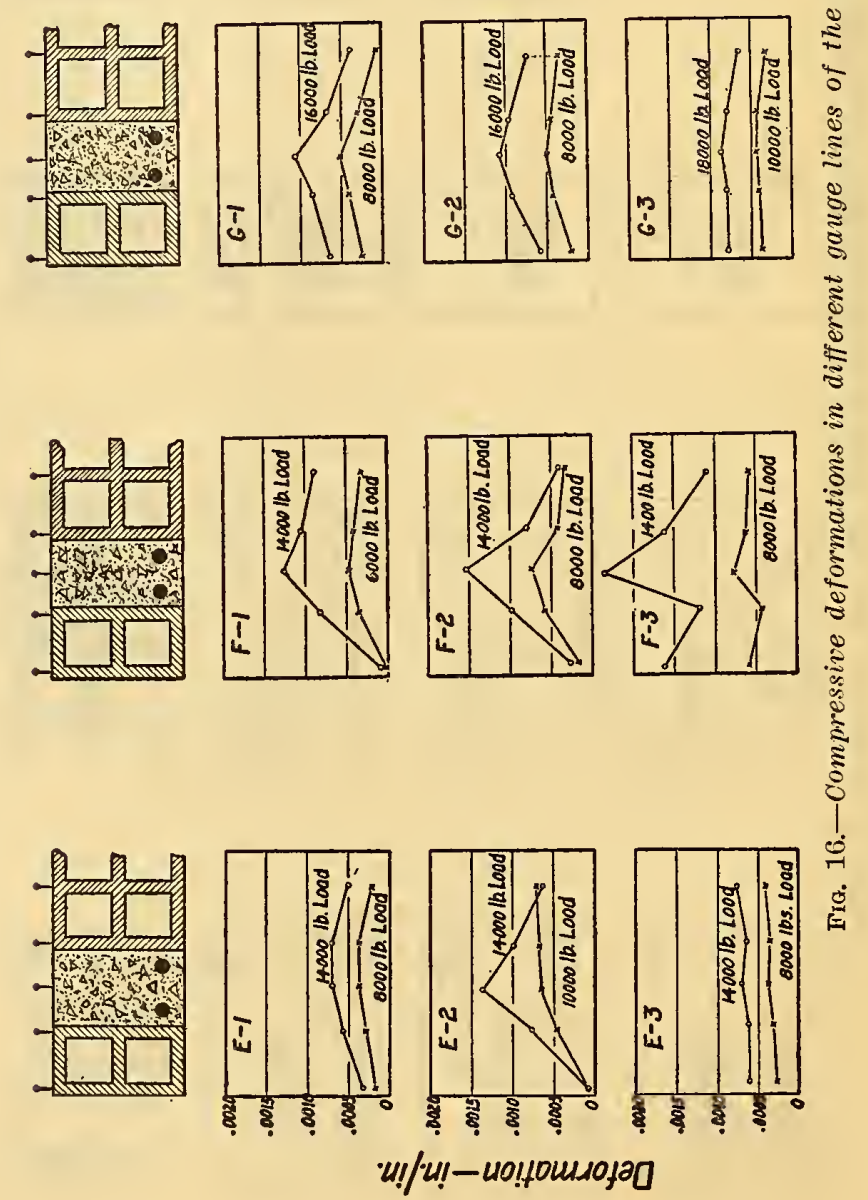
tations are given in the notation. The values $j_{0}$ determined from deformations corresponding to loads which produced a stress of $16,000 \mathrm{lbs} . /$ in. $^{2}$ in the reinforcement were used in all computations.

TABLE 6.-Results of shear tests A. BEAMS WITHOUT WEB REINFORCEMENT

[Span of supports equals 14 feet]

\begin{tabular}{|c|c|c|c|c|c|c|c|c|c|c|}
\hline \multirow{2}{*}{$\underset{\text { ber }}{\text { Beam- }}$} & \multirow{2}{*}{ Date made } & \multicolumn{2}{|c|}{ Storage } & \multirow{2}{*}{$\begin{array}{l}\text { Age } \\
\text { at } \\
\text { test }\end{array}$} & \multirow{2}{*}{$\begin{array}{l}\text { Tile } \\
\text { lot } \\
\text { num- } \\
\text { ber } \\
\text { (see } \\
\text { fig. } 5 \text { ) }\end{array}$} & \multirow{2}{*}{$\begin{array}{l}\text { Dis- } \\
\text { tance } \\
\text { be- } \\
\text { tween } \\
\text { loads }\end{array}$} & \multirow{2}{*}{$\begin{array}{l}\text { Maxi- } \\
\text { mum } \\
\text { load on } \\
\text { beam }\end{array}$} & \multicolumn{2}{|c|}{ Shearing stresses } & \multirow{2}{*}{$\begin{array}{l}\text { Cause of primary } \\
\text { failure }\end{array}$} \\
\hline & & $\begin{array}{l}\text { Out- } \\
\text { door }\end{array}$ & $\begin{array}{l}\text { In- } \\
\text { door }\end{array}$ & & & & & $v=\frac{V}{b^{\prime} j_{0} d}$ & $\frac{v_{\mathrm{m}}=}{\frac{V}{b_{\mathrm{m}}^{\prime} j_{\mathrm{o}} d}}$ & \\
\hline$A-1+\ldots \ldots$ & $\begin{array}{l}\text { Nov. } 23,1923 \\
\text { Dec. } 14,1923\end{array}$ & $\begin{array}{c}\text { Days } \\
35 \\
25\end{array}$ & $\begin{array}{c}\text { Days } \\
70 \\
78\end{array}$ & $\begin{array}{l}\text { Days } \\
105 \\
103\end{array}$ & - n- & $\begin{array}{r}\text { Feet } \\
10 \\
10\end{array}$ & $\begin{array}{l}\text { Pcunds } \\
47,100 \\
41,000\end{array}$ & $\begin{array}{r}\text { Lbs./in.2 } \\
145 \\
135\end{array}$ & Lbs./in..$^{2}$ & $\begin{array}{c}\text { Tension. } \\
\text { Do. }\end{array}$ \\
\hline Average. & & 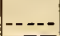 & $\ldots$ & $\ldots$ & & $\ldots$ & 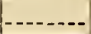 & 140 & & \\
\hline $\mathrm{B}-1$ & Nov. 30,1923 & 31 & 71 & 102 & . & 10 & 23,500 & 295 & & $\begin{array}{l}\text { Diagonal tension. } \\
\text { (Diagonal cracks at } \\
20,000 \text { pounds.) }\end{array}$ \\
\hline B-2 & do do & 32 & 71 & 103 & & 10 & 23,400 & 301 & & $\begin{array}{l}\text { Diagonal tension. } \\
\text { (Diagonal crack at } \\
18,750 \text { pounds.) }\end{array}$ \\
\hline B-3.. & Dec. 14,1923 & 25 & 77 & 102 & & 10 & 18,500 & 236 & & $\begin{array}{l}\text { Compression. } \\
\text { agonal crack at } \\
12,000 \text { pounds.) }\end{array}$ \\
\hline Average.. & 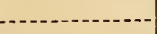 & - & --- & 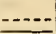 & $\ldots$ & $-\cdots$ & - - - - & 277 & & \\
\hline $\begin{array}{l}\mathrm{C}-1 \\
\mathrm{C}-2\end{array}$ & $\begin{array}{l}\text { Dec. } 28,1923 \\
\text { Jan. } 4,1924\end{array}$ & \begin{tabular}{|c|}
---- \\
----- \\
----- \\
\end{tabular} & $\begin{array}{l}101 \\
102 \\
101\end{array}$ & $\begin{array}{l}101 \\
102 \\
101 \\
\end{array}$ & $\begin{array}{l}2 \\
2 \\
2 \\
\end{array}$ & $\stackrel{(3)^{4}}{10}$ & $\begin{array}{c}15,500 \\
\left({ }^{3}\right) \\
26,300\end{array}$ & $\begin{array}{l}210 \\
(3) \\
357\end{array}$ & (3) $\begin{array}{l}118 \\
198\end{array}$ & $\begin{array}{l}\text { Diagonal tension. } \\
\text { Compression. }\end{array}$ \\
\hline $\mathrm{D}-1$ & Nov. 23,1923 & $\overline{35}$ & 69 & 104 & 3 & 11 & 63,400 & 675 & 405 & $\begin{array}{l}\text { Tension. (4-inch ver- } \\
\text { tical crack } 6 \text { inches } \\
\text { from north support } \\
\text { at } 52,500 \text { pounds.) }\end{array}$ \\
\hline D-2. & Dec. $\quad 7,1923$ & 27 & 76 & 103 & 3 & 10 & 42,100 & 511 & 295 & $\begin{array}{c}\text { Tension. (Diagonal } \\
\text { crack at } 37,400 \\
\text { pounds.) }\end{array}$ \\
\hline $\mathrm{D}-3$ & -. do do & 27 & 75 & 102 & 3 & 10 & 42,800 & 495 & 292 & Tension. \\
\hline Average.- & & -- & $\ldots$ & -- & $\ldots$ & - & & 560 & 331 & \\
\hline $\begin{array}{l}\mathbf{E}-1 \\
\mathbf{E}-2 \\
\mathbf{E}-3\end{array}$ & $\begin{array}{l}\text { Nov. } 30,1923 \\
\text { Dec. } 7,1923 \\
\text { Dec. } 14,1923\end{array}$ & $\begin{array}{l}31 \\
26 \\
24\end{array}$ & $\begin{array}{l}75 \\
76 \\
79\end{array}$ & $\begin{array}{l}106 \\
102 \\
103\end{array}$ & $\begin{array}{l}4 \\
4 \\
4\end{array}$ & $\begin{array}{l}10 \\
10 \\
10\end{array}$ & $\begin{array}{l}40,400 \\
37,900 \\
38,400\end{array}$ & $\begin{array}{l}455 \\
522 \\
429\end{array}$ & $\begin{array}{l}272 \\
309 \\
258\end{array}$ & $\begin{array}{l}\text { Do. } \\
\text { Do. } \\
\text { Diagonal tension. }\end{array}$ \\
\hline Average.. & & $-\ldots$ & $\ldots$ & --- & & -- & & 469 & 280 & \\
\hline $\begin{array}{l}F-1 \\
F-2 \\
F-3\end{array}$ & $\begin{array}{lr}\text { Dec. } & 28,1923 \\
\text { Jan. } & 4,1924 \\
\text { Jan. } & 11,1924\end{array}$ & 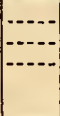 & $\begin{array}{l}103 \\
101 \\
103\end{array}$ & $\begin{array}{l}103 \\
101 \\
103\end{array}$ & $\begin{array}{l}2 \\
2 \\
2\end{array}$ & $\begin{array}{l}10 \\
10 \\
10\end{array}$ & $\begin{array}{l}30,500 \\
39,800 \\
33,700\end{array}$ & $\begin{array}{l}363 \\
523 \\
453\end{array}$ & $\begin{array}{l}206 \\
289 \\
249\end{array}$ & $\begin{array}{l}\text { Compression. } \\
\text { Do. } \\
\text { Compression. (Diag- } \\
\text { onal crack at } 27,700 \\
\text { pounds.) }\end{array}$ \\
\hline Average.- & & & - & -- & &.- & 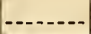 & 446 & 248 & \\
\hline$G-1 \ldots$ & Nov. 30,1923 & 32 & 72 & 104 & 3 & 10 & 44,800 & 533 & 315 & $\begin{array}{l}\text { Tension. (Diagonal } \\
\text { crack at } 44,500 \\
\text { pounds.) }\end{array}$ \\
\hline $\begin{array}{l}G-2 \ldots \ldots \\
G-3 \ldots\end{array}$ & $\begin{array}{l}\text { Dec. } 7,1923 \\
\text { Dec. } 28,1923\end{array}$ & 26 & $\begin{array}{r}78 \\
102 \\
\end{array}$ & $\begin{array}{l}104 \\
102\end{array}$ & $\begin{array}{l}3 \\
3 \\
\end{array}$ & $\begin{array}{l}10 \\
10\end{array}$ & $\begin{array}{l}36,400 \\
44,300\end{array}$ & $\begin{array}{l}467 \\
481\end{array}$ & $\begin{array}{l}274 \\
282\end{array}$ & $\begin{array}{l}\text { Diagonal tension. } \\
\text { Do. }\end{array}$ \\
\hline Average.. & & $-\cdots$ & $\ldots$ & $\ldots$ & - & $-\cdots$ & $-\cdots---$ & 494 & 290 & \\
\hline $\begin{array}{l}\mathbf{H}-1 \\
\mathbf{H}-2\end{array}$ & Nov. 23,1923 & $\begin{array}{l}36 \\
36\end{array}$ & $\begin{array}{l}66 \\
67\end{array}$ & $\begin{array}{l}102 \\
103\end{array}$ & $\begin{array}{l}1 \\
1\end{array}$ & $\begin{array}{r}9 \\
10\end{array}$ & $\begin{array}{l}36,700 \\
47,100\end{array}$ & $\begin{array}{l}384 \\
471\end{array}$ & $\begin{array}{l}226 \\
279\end{array}$ & $\begin{array}{l}\text { Tension. (Diagonal } \\
\text { Tension. ( }\end{array}$ \\
\hline H-3. & Dec. 7,1923 & 27 & 74 & 101 & 1 & 10 & 44,300 & 515 & 294 & $\begin{array}{l}\text { pounds.) } \\
\text { Tension. (Diagonal } \\
\text { crick at } 37,200 \\
\text { pounds.) }\end{array}$ \\
\hline Average.- & & & & & & & & 457 & 266 & \\
\hline
\end{tabular}

1 Beam C-1 failed by diagonal tension when loads were applied at lines 5 feet from supports. For this reason the values given are not conparable to those obtained when the loads were placed within 2 feet from the supports.

2 One tile in beam C-3 was broken before test.

aeam broken before shear test. 
TABLE 6.-Results of shear tests-Continued

B. BEAMS WITH BENT-UP BARS

[Beams supported on concrete blocks representing girder stem at center of beams]

\begin{tabular}{|c|c|c|c|c|c|c|c|c|c|c|}
\hline \multirow{2}{*}{$\begin{array}{l}\text { Beam num- } \\
\text { ber }\end{array}$} & \multirow{2}{*}{ Date made } & \multicolumn{2}{|c|}{ Storage } & \multirow{2}{*}{$\begin{array}{c}\text { Age } \\
\text { at } \\
\text { test }\end{array}$} & \multirow{2}{*}{$\begin{array}{l}\text { Tile } \\
\text { lot } \\
\text { num. } \\
\text { ber } \\
\text { (see } \\
\text { fig. 5) }\end{array}$} & \multirow{2}{*}{$\begin{array}{l}\text { Dis- } \\
\text { tance } \\
\text { he- } \\
\text { tween } \\
\text { loads }\end{array}$} & \multirow{2}{*}{$\begin{array}{l}\text { Maxi- } \\
\text { mum } \\
\text { load on } \\
\text { beam }\end{array}$} & \multicolumn{2}{|c|}{ Shearing stresses } & \multirow{2}{*}{$\begin{array}{l}\text { Cause of primary } \\
\text { failure }\end{array}$} \\
\hline & & $\begin{array}{l}\text { Out- } \\
\text { door }\end{array}$ & $\begin{array}{l}\text { In- } \\
\text { door }\end{array}$ & & & & & $v=\frac{V}{b^{\prime} j_{0} d}$ & $\frac{v_{\mathrm{m}}=}{\frac{V}{b_{\mathrm{m}}^{\prime} j_{\mathrm{o}} d}}$ & \\
\hline I-1.- & Jan. 11, 1924 & Days & $\begin{array}{c}D a y s \\
102\end{array}$ & $\begin{array}{c}\text { Days } \\
102 \\
\end{array}$ & & $\begin{array}{c}\text { Feet } \\
5.5\end{array}$ & $\begin{array}{l}\text { Pounds } \\
45,400\end{array}$ & $\begin{array}{r}\text { Lbs./in. }{ }^{2} \\
149 \\
\end{array}$ & Lbs./in. ${ }^{2}$ & Tension. \\
\hline $\mathrm{J}-1$. & Jan. $\quad 4,1924$ & & 102 & 102 & 2 & 5.5 & 42,700 & 512 & 281 & Tension and \\
\hline $\begin{array}{l}\mathrm{J}-2 \ldots \\
\mathrm{J}-3 \ldots\end{array}$ & $\begin{array}{ll}\text { Jan. } & 11,1924 \\
\text { Jan. } & 18,1924\end{array}$ & & $\begin{array}{l}101 \\
102\end{array}$ & $\begin{array}{l}101 \\
102\end{array}$ & $\begin{array}{l}2 \\
2\end{array}$ & $\begin{array}{l}5.5 \\
5.5\end{array}$ & $\begin{array}{l}44,900 \\
46,700\end{array}$ & $\begin{array}{l}535 \\
523\end{array}$ & $\begin{array}{l}297 \\
293\end{array}$ & $\begin{array}{l}\text { pression. } \\
\text { Compression. } \\
\text { Tension. }\end{array}$ \\
\hline A verage.- & & & $\ldots$ & 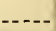 & & - & $\mid$ & 523 & 290 & \\
\hline $\begin{array}{l}\mathrm{K}-1 \\
\mathrm{~K}-2 \\
\mathrm{~K}-3\end{array}$ & $\begin{array}{lr}\text { Dec. } & 14,1923 \\
\text { Jan. } & 4,1924 \\
\text { Jan. } & 11,1924\end{array}$ & 26 & $\begin{array}{r}75 \\
102 \\
101\end{array}$ & $\begin{array}{l}101 \\
102 \\
101\end{array}$ & $\begin{array}{l}3 \\
3 \\
3\end{array}$ & \begin{tabular}{l|}
5.0 \\
5.5 \\
5.5
\end{tabular} & $\begin{array}{l}55,800 \\
47,300 \\
50,400\end{array}$ & $\begin{array}{l}595 \\
542 \\
568\end{array}$ & $\begin{array}{l}356 \\
313 \\
331\end{array}$ & $\begin{array}{l}\text { Do. } \\
\text { Do. } \\
\text { Do. }\end{array}$ \\
\hline Average.. & & & & & & -- & -1 & 568 & 333 & \\
\hline $\begin{array}{l}\mathbf{L}-1 \\
\mathbf{L}-2 \ldots \\
\mathbf{L}-3\end{array}$ & $\begin{array}{l}\text { Dec. } 21,1923 \\
\text { Dec. } 28,1923 \\
\text { Jan. } 18,1924\end{array}$ & & $\begin{array}{l}103 \\
101 \\
102\end{array}$ & $\begin{array}{l}103 \\
101 \\
102\end{array}$ & $\begin{array}{l}4 \\
4 \\
4\end{array}$ & $\begin{array}{l}5.0 \\
5.5 \\
5.5\end{array}$ & $\begin{array}{l}54,400 \\
46,300 \\
44,000\end{array}$ & $\begin{array}{l}580 \\
495 \\
442\end{array}$ & $\begin{array}{l}345 \\
295 \\
262\end{array}$ & $\begin{array}{l}\text { Do. } \\
\text { Do. } \\
\text { Do. }\end{array}$ \\
\hline Average.- & & & & & & & & 506 & 301 & \\
\hline $\begin{array}{l}M-1 \\
M-2 \\
M-3\end{array}$ & $\begin{array}{l}\text { Dec. } 21,1923 \\
\text { Jan. } 4,1924 \\
\text { Jan. } 11,1924\end{array}$ & & $\begin{array}{l}104 \\
102 \\
102\end{array}$ & $\begin{array}{l}104 \\
102 \\
102\end{array}$ & $\begin{array}{l}3 \\
3 \\
3\end{array}$ & $\begin{array}{l}5.5 \\
5.5 \\
5.5\end{array}$ & $\begin{array}{l}42,900 \\
46,100 \\
46,500\end{array}$ & $\begin{array}{l}474 \\
528 \\
518\end{array}$ & $\begin{array}{l}280 \\
307 \\
301\end{array}$ & $\begin{array}{c}\text { Compression. } \\
\text { Tension. } \\
\text { Do. }\end{array}$ \\
\hline A verage.- & & & 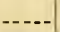 & & & - - - & & 507 & 296 & \\
\hline $\begin{array}{l}\mathrm{N}-1 \\
\mathrm{~N}-2 \ldots \\
\mathrm{N}-3 \ldots \ldots\end{array}$ & $\begin{array}{l}\text { Dec. } 14,1923 \\
\text { Dec. } 21,1923 \\
\text { Jan. } 18,1924\end{array}$ & 25 & $\begin{array}{r}77 \\
102 \\
101\end{array}$ & $\begin{array}{l}102 \\
1.02 \\
101\end{array}$ & $\begin{array}{l}3 \\
3 \\
3\end{array}$ & $\begin{array}{l}5.0 \\
5.0 \\
5.5\end{array}$ & $\begin{array}{l}50,700 \\
59,900 \\
48,400\end{array}$ & $\begin{array}{l}580 \\
645 \\
585\end{array}$ & $\begin{array}{l}340 \\
378 \\
336\end{array}$ & $\begin{array}{l}\text { Do. } \\
\text { Do. } \\
\text { Do. }\end{array}$ \\
\hline Average.- & & & & $\ldots$ & & 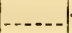 & & 603 & 351 & \\
\hline $\begin{array}{l}\mathrm{O}-1 \\
\mathrm{O}-2 \\
\mathrm{O}-3 .\end{array}$ & $\begin{array}{l}\text { Dec. } 21,1923 \\
\text { Jan. } 11,1924 \\
\text { Jan. } 18,1924\end{array}$ & & $\begin{array}{l}103 \\
102 \\
102\end{array}$ & $\begin{array}{l}103 \\
102 \\
102\end{array}$ & $\begin{array}{l}1 \\
1 \\
1\end{array}$ & $\begin{array}{l}5.0 \\
5.5 \\
5.5\end{array}$ & $\begin{array}{l}45,500 \\
40,700 \\
38,100\end{array}$ & $\begin{array}{l}617 \\
548 \\
448\end{array}$ & $\begin{array}{l}353 \\
312 \\
276\end{array}$ & $\begin{array}{l}\text { Do. } \\
\text { Do. } \\
\text { Do. }\end{array}$ \\
\hline$A$ & & & & & & & & 538 & 314 & \\
\hline
\end{tabular}

The two values of shearing stresses given in Table 6 correspond to two breadths of webs considered to be effective in resisting shearing stresses. The values $v$ were computed on the assumption that the shear was resisted by the concrete without assistance from the tiles. The values $v_{\mathrm{m}}$ were computed on the assumption that the shear was resisted by composite webs made up of the concrete and all of the vertical shells and webs of the tiles, in which the shearing stress in the tiles was equal to the shearing stress in the concrete ribs.

The average of the maximum shearing stresses $v$ in the combination beams were much greater than stresses which caused the diagonal tension failures of the concrete beams B. Previous tests of concrete beams indicate that stresses much less than those developed would be expected to cause diagonal tension failures. It is evident, therefore, that the tiles assisted in resisting shearing stresses.

It was to be expected that the tiles should be effective in resisting a portion of the shearing stresses when it was found that the 
Technologic Papers of the Bureau of Standards, Vol. 19

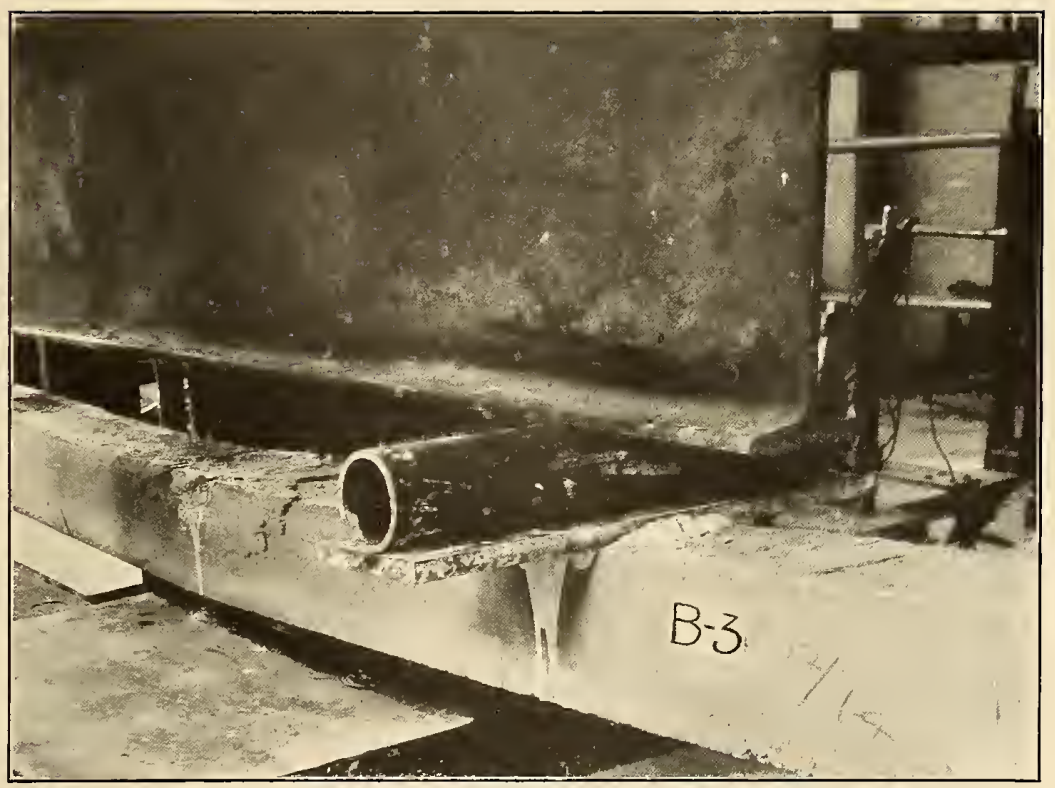

FIG. 17.-Beam B-S after compressive failure

Note diagonal crack

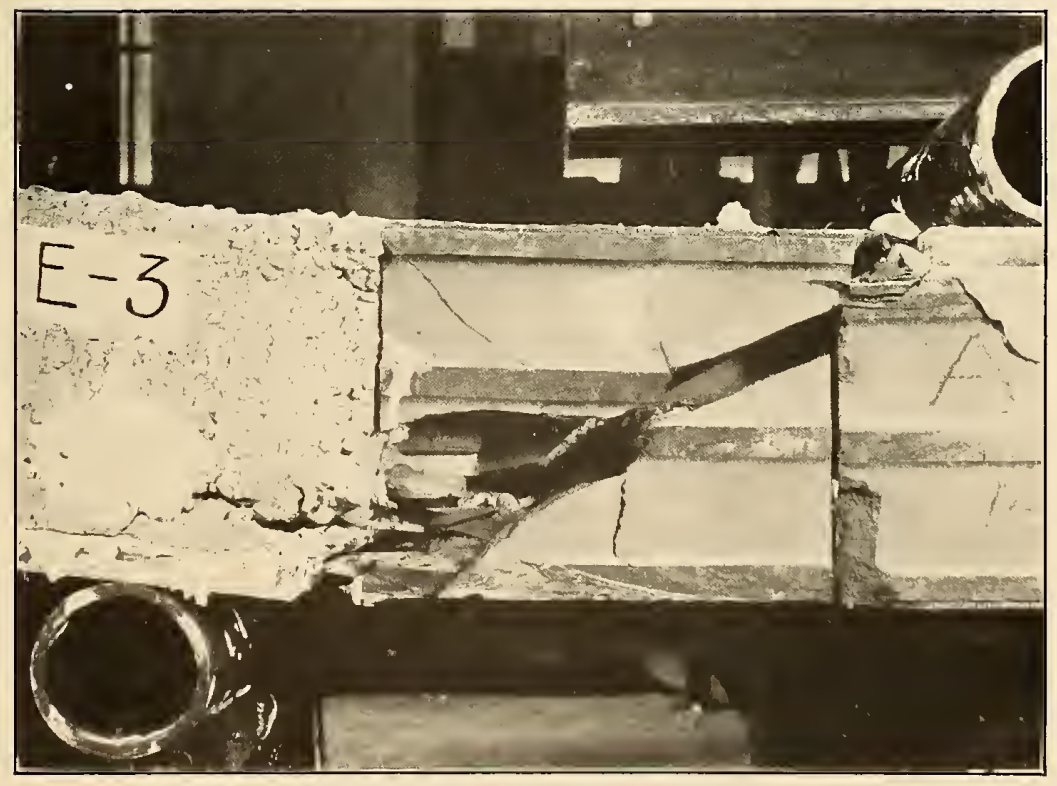

FIG. 18.-Diagonal tension jailure of beam $E-3$ 
Technologic Papers of the Bureau of Standards, Vol. 19

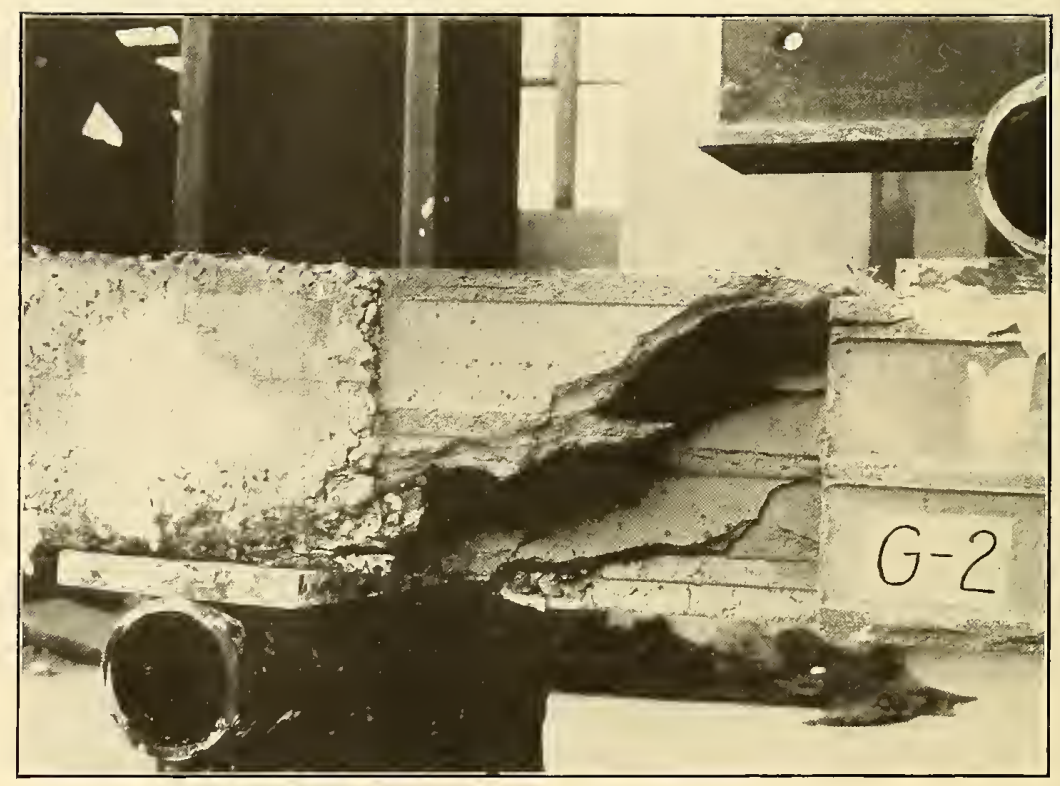

Fig. 19.-Diagonal tension failure of beam $G-2$ 
bond between them and the concrete was sufficient to cause highcompressive stresses in the tiles, but the presence of open cross joints between the tiles has caused some doubt as to their value. However, these cross joints, although greater in extent, are not dissimilar in effect to the vertical tension cracks which always appear in a reinforced concrete beam under working loads. These tension cracks are in a part of the section which is considered to be resisting the maximum shearing stresses. The direction of the tensile stresses which cause diagonal tension failures (see figs. 18 and 19 ) is such that the joints in the tiles affect but relatively small distances. In the beams which failed by diagonal tension cracks in the center tiles were found to lie in the same plane with corresponding cracks in the concrete. Cracks crossed the tile joints without break of continuity or change of direction.

Two of the 8 by 8 inch concrete beams $B$ failed by diagonal tension, and a typical diagonal crack had appeared in the third before it failed in compression (see fig. 17). The average of the maximum shearing stresses in the two concrete beams which failed by diagonal tension was $298 \mathrm{lbs}$./in. ${ }^{2}$, and as the manner of loading was the same for those beams as for the combination beams the value of the tiles in resisting shearing stresses may be estimated by comparing the maximum shearing stresses developed in the combination beams with the stress which caused the failure of these concrete beams.

On the basis that the concrete ribs in the combination beams had a maximum shearing strength of $298 \mathrm{lbs}$. $/ \mathrm{in.}^{2}$ over their $b^{\prime} j_{0} d$ section under the conditions of test, one row of tile (one-half of the entire amount) in each of the beams was at least equivalent to the following widths of concrete in resisting shearing stresses: Beams E, 2.4 inches; beams D, 3.4 inches; beams G, 2.5 inches; beams F, 1.9 inches; beams H, 2.2 inches. These widths correspond to the following percentages of the total thickness of the vertical tile shells and webs in each row of tiles: Beams E, 85 per cent; beams D, 124 per cent; beams G, 91 per cent; beams F, 63 per cent; beams H, 73 per cent. Although beam $\mathrm{C}-1$ failed by diagonal tension, the result obtained is not comparable on account of the difference in the positions of the loads.

(b) BEAMS WITH WEB REINFORCEMENT

The results of the shear test of the short beams, the details of which are shown in Figure 2, are given in Table 6. All but three of these beams failed in tension. The position of the tension cracks preceding failures was approximately the same in all beams and first appeared on the top and sides of the beams, either in the planes of the vertical faces of the blocks of concrete or at slightly greater distances from the centers of the beams. In tension failures these 
cracks gradually widened as the loads were increased until, after the steel had yielded a sufficient amount, the final failures were caused by crushing the concrete. Since no tension cracks were noted in the concrete blocks, it appear's that the critical sections for the tensile stresses due to negative bending moment were at the planes of the vertical faces of the blocks representing the supporting girders.

In the three beams which failed by compression the failures occurred in a narrow strip from 2 to 4 inches wide adjacent to the concrete blocks. Assuming that the shear was resisted by the concrete ribs without assistance from the tiles, the average shearing resistance for all of the combination beams would be $541 \mathrm{lbs}$./in. ${ }^{2}$ Assuming that the vertical shells and webs of the tiles resisted shear equal in intensity to that in the concrete, the average of the maximum computed shearing stresses, $\mathrm{v}_{\mathrm{m}}$, in the composite ribs was $318 \mathrm{lbs}$. $/ \mathrm{in}^{2}$

None of the short beams failed by diagonal tension and, as there were no visible indications of approaching failure in this manner, it was apparent that their maximum shearing strength had not been reached. Since the tension reinforcement was insufficient to develop the full shearing resistance of the beams, the results of the tests do not indicate what difference in shearing resistance there may have been between the beams with and those without a concrete flange adjacent to the concrete block representing a supporting girder. The stresses developed, however, were sufficiently high in both types to exceed greatly stresses produced with ordinary spans and loads. The stresses developed were greater than for the beams with no web reinforcement. The manner of failure was such, howevel, that the value of the bent-up bars in resisting shearing stresses could not be determined.

\section{GENERAL COMMENTS}

Some features of the tests indicate that somewhat greater assistance from the tile may be expected in a complete floor slab than in these beams. The outer tiles in the combination beams without topping were not as effective in resisting stresses as an equal section would have been in a complete floor slab for the deformations in the tiles at the outer edges of the beams were less than the deformations would have been at the same relative position in a completed slab. Part of the top shells, which would have been effective to some extent in resisting bending stresses, were cut away in order to maintain the dimensions of the test specimens. In all computations, however, the two outer rows of tile sections were considered to be equivalent to a single row of tiles. The maximum compressive strengths of neither the combination beams containing the hard tiles nor the beams with 
a concrete topping were developed, and only four of the combination beams failed by diagonal tension. These considerations indicate that values of the tiles in resisting stresses may be greater than is giren by the test results.

An examination of the beams after failure showed that the method used in blocking the ends of the tiles to prevent the concrete from flowing into the cells was effective and that the areas of the concrete sections used in computations were not increased in this manner. Furthermore, no unusual effort was made in the construction of the beams to secure a bond between the concrete and tiles. In this regard construction methods which are believed to be consistent with those employed in similar work were followed.

There are, howerer, some cautions which should be noted in interpreting the results of these tests for use in design which, if not given proper consideration, may result in a weakness not indicated by the tests:

1. It is apparent that the tiles can not be effective in resisting stresses unless the bond between the concrete and tiles has sufficient strength to maintain the integrity of the construction. In order to place the concrete properly in the 4-inch ribs between the rows of tiles it is necessary that the concrete be thoroughly worked around the reinforcement and tiles.

2. The tension reinforcement in the long beams was provided with special anchorage by means of looks in the solid concrete sections beyond the supports. This concrete section served to join the two ribs. These provisions probably had an important effect on the shearing strengths developed.

3. The tiles in the test beams were laid with the axes of their cells parallel to the direction of the span and with the joints in adjacent rows staggered. Other arrangements may not give equal strengths.

4. The effects of repeated loads, vibrations, shrinkage of the concrete, and thermal expansion and contraction were not within the scope of these tests.

5. The values of equivalent widths shown in Figures 12, 13, and 14. were employed there merely as an arbitrary device for studying the test data which pertain to loads less than the maximum. These values should not be used in design, since the equivalent widtlis found from a study of the compression and shear failures were smaller.

Although the above cautions should be noted in the design and construction of similar floor slabs in order to apply the results of these tests, it is believed that the quality of the workmanship used in making the test specimens was not superior to that which may reasonably be expected in building construction. 


\section{SUMMARY}

The results of these tests seem to warrant the following conclusions :

For beams without topping.-1. In resisting bending stresses each hollow tile and concrete rib in the combination beams was equivalent in strength to a rectangular concrete beam having a width at least equal to the width of the concrete rib plus $1.3(s+w) \frac{E_{\mathrm{t}}}{E_{0}}$

where $\mathrm{E}_{\mathrm{c}}$ is taken as $2,000,000 \mathrm{lbs}$./in. ${ }^{2}$ and

$s=$ thickness of one vertical tile shell, inches.

$\imath v=$ thickness of one vertical tile web, inches, and

$\mathrm{E}_{\mathrm{t}}=$ modulus of elasticity of the tiles, lbs./in. ${ }^{2}$

2. The average strength of the beams having mortar in the cross joints between the tiles was only slightly greater than the average strength of the corresponding beams having open joints.

3. The effect of the tiles at loads less than the maximum upon the deformations in the concrete, the position of the neutral axis, and the deflections was apparently equal to or greater than the effect of adding a width of concrete to each concrete rib equal to $2(s+w) \frac{E_{\mathrm{t}}}{E_{\mathrm{c}}}$

4. The compressive stresses in the shells of the hard tiles in contact with the concrete ribs were greater than the compressive stresses in the adjacent concrete.

For beams with a topping.-The top shells of the tiles in contact with the concrete seemed to be as effective in resisting compressive stresses as an equal area of concrete in the same location.

For both types of beams.- 1 . On the assumption that the shearing resistance of the concrete in the combination beams was equal to its resistance in the concrete beams which failed by diagonal tension, the assistance of the two rows of half tile adjacent to each concrete rib was at least equivalent to the following widths of concrete in resisting shearing stress: Tile of lot $1,2.2$ inches; tile of lot 2 with mortar joints, 1.9 inches; tile of lot $3,3.4$ inches; tile of lot 3 with mortar joints, 2.5 inches; tile of lot $4,2.4$ inches.

2. The combination beams containing bent-up bars for web reinforcement resisted an average shearing stress over the $b^{\prime} j_{0} d$ section. of concrete of $541 \mathrm{lbs} . / \mathrm{in}^{2}{ }^{2}$ without visible indications of diagonal tension failures.

3. The strength of the bond between the concrete and tiles even with open joints was sufficient to permit failures of the beams by compression and diagonal tension. There seemed to be no failures caused primarily by the failure of this bond.

Washington, March 14, 1925. 